\title{
MONETARY TRANSMISSION MECHANISM IN TRANSITION ECONOMIES: SURVEYING THE SURVEYABLE
}

\author{
BALÁZS ÉGERT \\ RONALD MACDONALD
}

\author{
CESIFO WORKING PAPER NO. 1739 \\ CATEgory 6: Monetary Policy and InTERnational FinanCE \\ JUNE 2006
}

An electronic version of the paper may be downloaded

- from the SSRN website:

- from the RePEc website:

- from the CESifo website:

www.SSRN.com

www.RePEc.org

www.CESifo-group.de 


\title{
MONETARY TRANSMISSION MECHANISM IN TRANSITION ECONOMIES: SURVEYING THE SURVEYABLE
}

\begin{abstract}
This paper surveys recent advances in the monetary transmission mechanism (MTM). In particular, while laying out the functioning of the separate channels in the MTM, special attention is paid to exploring possible interrelations between different channels through which they may amplify or attenuate each others' impact on prices and the real economy. We take stock of the empirical findings especially as they relate to countries in Central and Eastern Europe, and compare them to results reported for industrialised countries, especially for the euro area. We highlight potential pitfalls in the literature and assess the relative importance and potential development of the different channels.
\end{abstract}

JEL Code: E31, E51, E58, F31, O11, P20.

Keywords: monetary transmission, transition, Central and Eastern Europe, credit channel, interest rate channel, interest-rate pass-through, exchange rate channel, exchange rate passthrough, asset price channel.

\author{
Balázs Égert \\ Austrian National Bank \\ Vienna \\ Austria \\ balazs.egert@oenb.at
}

\author{
Ronald MacDonald \\ Department of Economics \\ University of Glasgow \\ Glasgow G12 8QQ \\ Scotland, UK \\ r.macdonald@socsci.gla.ac.uk
}

May 22, 2006

We are indebted to Csilla Horváth and Balázs Vonnák for extensive helpful comments and suggestions. We also thank Markus Arpa, Peter Backé, Zoltán M. Jakab, Markus Knell, Mihály M. Kovács, Márton Nagy and György Szapáry for useful comments and discussion. The views expressed in the paper are those of the authors and do not necessarily reflect those of the Oesterreichische Nationalbank or of any of the institutions the authors are affiliated with. 


\section{Introduction}

Given its potential to affect the real economy, monetary policy has been subject to intense academic scrutiny over the years in the Economics profession. Popular wisdom asserts that although ineffective in the longer run, monetary policy is a powerful tool in influencing economic activity at shorter horizons and the New Open Economy Macreoconomics suggests that monetary policy can have powerful effects in the long-run as well. According to the stylised fact given in Christiano et al. (1996), in the US, monetary policy actions impact on the real sector with an average delay of 4 months and this can persist for up to 2 years. This finding is also borne out in Romer and Romer (1989). Another salient feature of monetary policy, put forth in Barth and Ramey (2000), is that small changes in short-term interest rates canresult in large changes in output (an amplification effect). These findings should be regarded as suggestive rather than conclusive, as the lag of the pass-through to the real economy appears to change over time and across countries.

Bernanke and Gertler (1995) have argued that the mechanism through which monetary policy actions are transmitted to the real economy is something of a black box. Attempts at understanding the mechanism has given rise to a large body of theoretical literature and to a plethora of empirical papers that seek to match theory with real data. The most traditional explanation for the link is the interest rate channel developed in textbook IS-LM models. However, the early observation that the interest rate channel cannot neatly explain output fluctuations has given birth to the credit channel literature (including the bank lending, the broad lending, the bank capital channel and the role of trade credit). Finally, asset prices, such as the exchange rate and stock prices, are also believed to constitute a bridge between nominal and real variables and this has had important policy implications in terms of what variables enter a central bank's interest rate rule when targeting inflation.

In this paper we analyze the separate functioning of the different channels, and we also highlight possible interlinkages between the different channels through which they may magnify or counteract each others' influence in the monetary transmission mechanism (see Figure 1). We have a special emphasis on transition economies of Central and Eastern Europe (CEE) and there are, at least, two important reasons why the monetary transmission mechanism of these economies is worth studying. First, a genuine and precise understanding of how fast, and to what extent, a change in the central bank's interest instrument modifies inflation lies at the heart of inflation targeting. An increasing number of transition countries already make use of inflation targeting, or have recently started using it, or are planning to do so. Second, the forthcoming full euro area participation of the countries that entered the EU in May 2004 raises the issue of whether the already heterogeneous euro area, in terms of the monetary transmission mechanism, would grow even more heterogeneous. But

a more important question is: will the ECB be efficient in influencing prices and real variables when the new EU member states adopt the euro?

Despite the importance of this question, the empirical literature dealing 
with Central and Eastern Europe appears to be fragmented, in the sense that different aspects of the MTM are analysed separately and the big picture is hidden behind the individual studies. This paper makes an attempt to bring together different branches of the literature. In particular, we take stock of the empirical issues relating to countries in Central and Eastern Europe, and present them in a systematic way. In addition, we direct attention to potential pitfalls in the literature and assess the relative importance and the potential development of the different channels ${ }^{1}$.

Given the large gap in terms of financial sector development that distinguishes CEE from euro area countries, it is of fundamental importance to evaluate whether the monetary transmission operates differently and whether a homogeneous approach to monetary policy for CEE and euro area countries may lead to sharply different effects on the respective economies.

The paper is structured as follows. Section 2 provides an overview of the development of the monetary policy framework in transition economies. Sections 3 to 6 survey the theoretical literature and summarise the empirical findings for the CEE transition economies for the interest channel, the credit channel, the exchange rate channel and the asset price channel, respectively. Section 7 analyses studies based on the VAR methodology. Finally, Section 8 concludes by speculating on possible future developments of the different channels.

\section{A Brief Overview of the Final and Intermedi- ate Objectives of Monetary Policy in Transi- tion Economies}

To fully understand how the monetary transmission mechanism has evolved in CEE countries over the past twenty years, and how it works now, it is necessary to review the development of the monetary policy framework, on which central banks in Central and Eastern Europe relied at the time economic transition was launched and during the subsequent transition period.

Generally, the profound economic transformation which occurred in the late 1980s and early 1990s involved, among others, a liberalisation of prices and trade, which resulted in a surge of very high inflation and large external imbalances. This is why most central banks had at that time more than one final objective for their macroeconomic policy, such as the pursuit of price stability and external stability. However, over time, the most advanced countries of the region adopted a single price stability goal (Czech Republic, Hungary or Poland), while others still today have a dual objective (Croatia). Countries with large credibility problems introduced currency board arrangements either at an early stage (Estonia and Lithuania) or after a banking crisis (Bulgaria). Hence, the final and the intermediate objectives of these central banks are reduced to securing the proper functioning of the currency board.

\footnotetext{
${ }^{1}$ It should be noted that the coverage of the different channels in the paper is not balanced because some areas are more researched than others.
} 
Prior or at the time of the transition process, central banks relied on a monetary aggregate (e.g. Hungary, 1987-1991) as intermediate target. However, it quickly became clear that money demand functions are unstable when fundamental changes occur in the real economy and in the monetary policy framework ${ }^{2}$. Hence, most central banks of the region switched to the nominal exchange rate (Hungary, Poland) or to the real exchange rate (Slovenia) as an intermediate objective. Alternatively, some countries adopted a double intermediate objective by complementing monetary aggregates with the nominal exchange rate (Czechoslovakia, and after its split-up in 1993, the Czech Republic and Slovakia). With the move of some countries to inflation targeting (the Czech Republic and Poland), these intermediate objectives were replaced by inflation forecasts.

The transformation of the monetary policy framework went hand in hand with changes in monetary policy instruments as well. Because of the absence of financial markets, and because the long prevailing soft budget constraint in the banking sector and in the non-financial corporate sector economic agents were insensitive to interest rate signals. Instead direct administrative measures such as credit ceilings, direct interest rate control and reserve requirements were being used to control credit growth and banking sector liquidity. Some countries like Bulgaria, Croatia and Romania have, until recently, been heavily reliant on these direct measures to curb, for example, credit growth (marginal reserve requirements on the growth of FX denominated loans)

However, with the development of the interbank money market, indirect instruments based on the proper functioning of markets were introduced. In particular, central banks started to influence very short-term interest rates by imposing an interest corridor, which is typically maintained by means of open market operations.

\footnotetext{
${ }^{2}$ There is an ongoing debate on the stability of money demand functions in transition economies. Some backward looking studies argue that money demand was stable in transition economies like Hungary and Poland (Buch, 2001), in a panel of 6 CEECs (Chowdhury and Fidrmuc, 2004), and, perhaps surprisingly, for Albania (Kalra, 1998), Belarus (Pelipas, 2005) and Mongolia (Sløk, 2002). Dabušinskas (2005) provides some evidence for an instable money demand function in Estonia. Perhaps more importantly, at the time of the adoption of new monetary policy frameworks in the early 1990s and at later stages of transition, policymakers faced large uncertainty as to whether money demand will remain stable after the change (Neményi, 1996; and Kokoszcziński, 1996). In addition, in some cases, money demand functions can best be modelled by means of the Cagan model, which links money demand to inflationary expectations (see Slvavova (2003) for Bulgaria, Choudhry (1998) for Russia and Budina et al. (2002) for Romania) or the interest rate (beside output the most important determinants of standard money demand functions) turns out to play no role in Latvia (Tillars, 2004) or in Mongolia (Sløk, 2002). Large shifts in monetary policy admittedly yields different functional forms of money demand (Slavova, 2003). Also, some authors point out that the process of dollarisation or de-dollarisation may also explain why money demand function is found unstable in some countries (Oomes and Ohnsorge, 2005). A final cautionary note is that money demand estimations tend to be unreliable not only for transition economies but also in general (Knell and Stix, 2003)
} 
Figure 1. Overview of the Transmission Mechanism

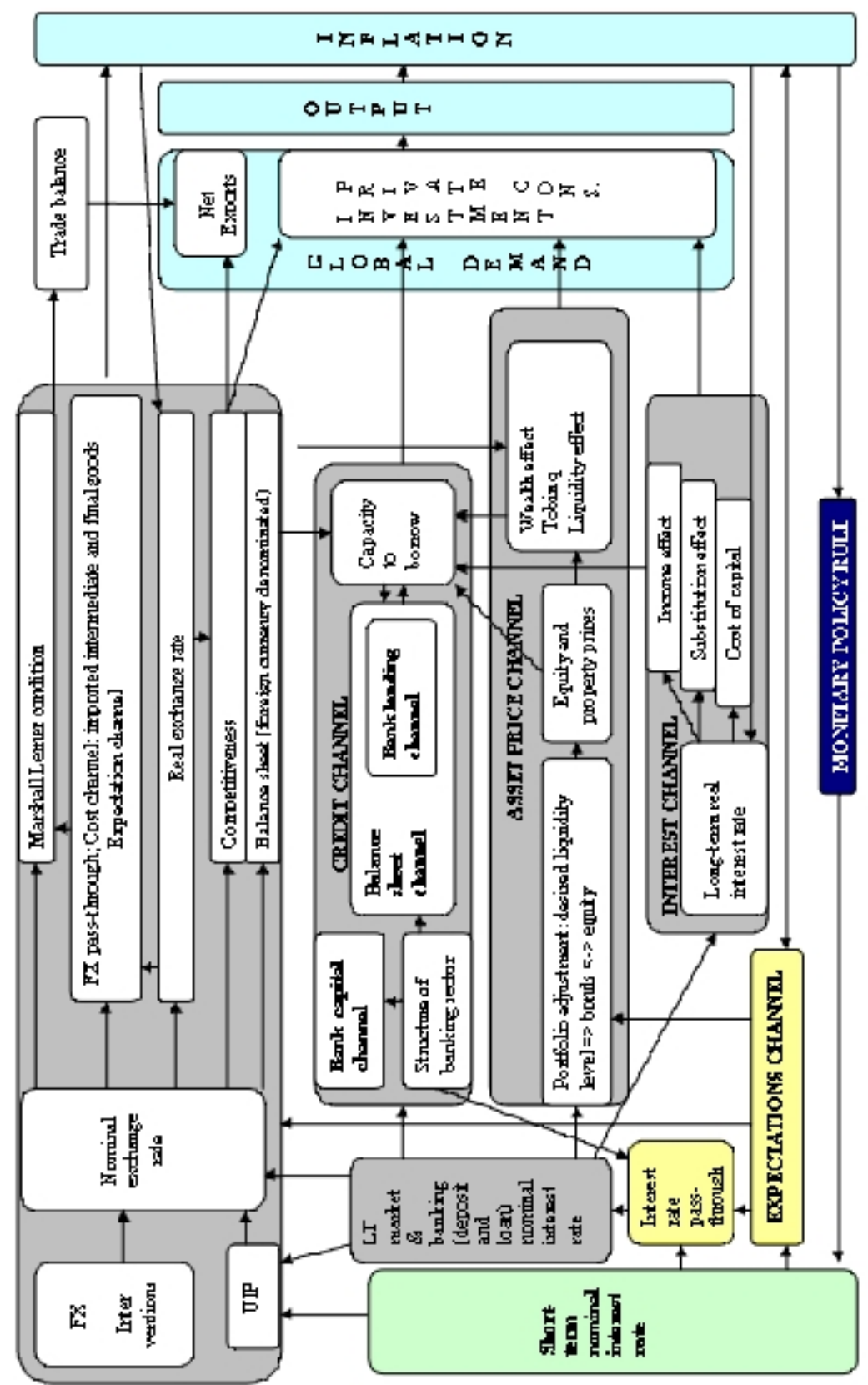




\section{The Interest Rate Channel and the Transmis- sion Process}

The interest rate channel, encapsulated in the traditional IS-LM model, can be dissected into two distinct stages: (a) the transmission from short-term nominal interest rates to long-term real interest rates, and (b) the channel through which aggregate demand and production are affected by real interest rate developments.

\subsection{First Stage: Interest Rate Pass-Through}

\subsubsection{Theoretical Aspects}

Crucial to the effectiveness of any monetary policy action is how changes in the key monetary policy rate are transmitted, first, onto market rates at the longer end of the maturity spectrum, and, second, how bank deposit and lending rates are affected by such a change in market rates.

The connection between short- and long-term (market) nominal interest rates is provided by the term structure of interest rates. The slope and the dynamics of the term structure can best be explained using a combination of standard theories, such as the liquidity preference view (that is, investors require a liquidity premium for holding less liquid (usually long-term) assets or market segmentation (that is, short-term and long-term interest rates could be determined independently in segmented markets). But most importantly, it is a widely held view that the expectation conjecture is at the heart of the shape of the yield curve. According to this position, long-term interest rates are obtained as an average of expected future short-term interest rates. So, expectations as to whether, say, an interest rate hike is high enough to curb inflation will dominate the yield curve. This is often referred to as the expectation channel, which also plays an important role in the asset price and exchange rate channels.

Another facet of the transmission is how interest rate changes in the money and capital markets influence bank deposit and loan interest rates. The connection between market rates and bank lending can be illustrated using a marginal cost pricing model, where the price set by the bank $\left(i^{B}\right)$ equals the marginal cost of funding approximated by a market interest rate $\left(i^{M}\right)$ and a constant mark-up $(\mu)$ (deBondt, 2002):

$$
i^{B}=\mu+\beta \cdot i^{M}
$$

The pass-through parameter $\beta$ is equal to 1 under perfect competition and complete information. However, full (or perfect or complete) pass-through may not prevail if markets are imperfect and in the presence of asymmetric information. In particular, the degree of pass-through crucially hinges on whether or not the elasticity of demand for deposits and for loans to the deposit and lending rate, respectively, is 1 . Demand elasticities lower than one result in an incomplete pass-through $(\beta<1)$, and a combination of factors may cause 
the demand elasticities to become less than unity. First, the imperfect substitution between bank deposits and other investment facilities bearing the same maturity and flexibility (money market funds, T-bills and alike) on the one hand, and between bank lending and other types of external finance (equity or bond markets) reduces demand elasticities: a low degree of competition between banks and between banks and non-bank financial intermediaries lowers the sensitivity of demand for deposits and loans to the interest rate. Second, demand elasticities may be reduced if it is costly to change bank (switching costs). In addition, market segmentation due to switching costs and a high concentration of the banking sector can lead to monopolistic market structure preventing the pass-through to be unity.

The presence of asymmetric information (adverse selection and moral hazard) may render bank lending rates less responsive to changes in the key rate. At the same time, the interest rate pass-through to lending rates can exceed 1 (overshooting) in the event that banks charge higher interest rates in an attempt to counteract higher risks resulting from asymmetric information, rather than reducing the supply of loan (deBondt, 2002).

If competition is weak, the interest rate pass-through may vary over the interest rate cycle. When interest rates are on the rise, banks may adjust their lending rates quicker than their deposit rates. Conversely, if interest rates are falling, they may tend to decrease their deposit rates more rapidly than their lending rates (Hannan and Berger, 1992 and Weth, 2002). Sander and Kleimeier (2004a) stress that the degree of competition is more important for the passthrough for deposit rates than for lending rates, since problems related to asymmetric information are less important for the former.

In addition to this, the pass-through from the policy rate to retail rates may not only be incomplete in the long-run, but could be sluggish in the short-run due to an array of other factors. First, banks respond slowly to changes in the market rates in the presence of adjustment or menu costs. They may decide to adjust lending rates less frequently but when they do adjust the movement is substantial.Second, the way in which banks adjust their lending rates depends on the maturity mismatch of their loan and deposit portfolio. The more long-run loans are covered by long-term deposits, the less pressure banks feel to adjust their lending rates. In other words, it matters how responsive their liability side to market rates is. Banks with extensive recourse to long-run deposit such as saving deposits which are not particularly affected by market rates, are slower to adjust their lending rates as compared to those banks whose liability side relies more heavily on deposits or other forms of financing, which are more sensitive to market rates (Weth, 2002).

Third, if banks have long-term relationships with their customers, they may want to smooth interest rate changes. This may apply to universal banks and the so-called "Hausbank".

Finally, macroeconomic conditions may also have a bearing on the the passthrough mechanism. For example, during periods of rapid economic growth, i.e. under favourable economic conditions, banks may find it easier to pass on changes in the interest rate to their lending and deposit rates more rapidly. 
Higher inflation may also favour more rapid interest rate pass-through given that prices may be adjusted more frequently in a high-inflation regime than as compared to a low-inflation regime. Increased uncertainty, reflected in higher interest rate volatility may, however, lower the interest rate pass-through as banks may want to get a true picture of the underlying position.

Importantly, the pass-through to loan rates is intimately related to the credit market in general and to the functioning of the credit channel in particular. As we will argue later in this paper, disequilibrium in the credit market may either diminish the completeness of the pass-through or may help in moving towards full pass-through. A related issue worth mentioning here is how easily banks can refinance themselves. Banks (usually smaller banks) for which external financing is more difficult to access to - because of asymmetric information problems increase their deposit rates to attract more deposits, and, consequently, they also adjust their lending rates ${ }^{3}$. By the same token, more liquid and more capitalised banks adapt their retail rates slower to changes in the monetary policy rate than less liquid banks with less capital (Gambacorta, 2004).

\subsubsection{Methodological and Empirical Issues}

In practice, the interest rate pass-through is usually investigated using an error correction model of the following form provided the interest rate series are I(1) processes and are cointegrated:

$$
\Delta i_{t}^{B}=\alpha_{0}+\rho\left(i_{t-1}^{B}-\mu-\beta i_{t-1}^{M}\right)+\delta \Delta i_{t}^{M}+\epsilon_{t}
$$

where $\beta$ is the long-run pass-through and $\delta$ measures contemporaneous adjustment. If contemporaneous adjustment is below 1 , adjustment is said to be sluggish. The lag length with which the retail rate $\left(i_{t}^{B}\right)$ fully adjusts to the long-run pass-through $(\beta)$ is given by the expression: $(1-\delta) /|\rho| \cdot{ }^{4}$

\footnotetext{
${ }^{3}$ However, as it will be discussed at a later stage, membership to a larger network of banks may ease the external finance constraint and thus will decrease the sensitivity of deposit and loan rates to changes in market rates.

${ }^{4}$ Equation (2) can be extended to a general ARDL model to account for more short-term dynamics as in equation (3):

$$
\Delta i_{t}^{B}=\alpha_{0}+\rho\left(i_{t-1}^{B}-\mu-\beta i_{t-1}^{M}\right)+\sum_{j=0}^{l} \delta_{j} \Delta i_{t-j}^{M}+\sum_{j=1}^{l} \phi_{j} \Delta i_{t-j}^{B}+\epsilon_{t}
$$

The following specifications can be estimated in the event that $i_{t}^{B}$ and $i_{t}^{M}$ are not cointegrated, but stationary, (equation 4) or are not cointegrated and non-stationary (equation 5):

$$
\begin{gathered}
i_{t}^{B}=\alpha_{0}+\sum_{j=0}^{l} \delta_{j} i_{t-j}^{M}+\sum_{j=1}^{l} \phi_{j} i_{t-j}^{B}+\epsilon_{t} \\
\Delta i_{t}^{B}=\alpha_{0}+\sum_{j=0}^{l} \delta_{j} \Delta i_{t-j}^{M}+\sum_{j=1}^{l} \phi_{j} \Delta i_{t-j}^{B}+\epsilon_{t}
\end{gathered}
$$

where the long-term impact ( $\beta$ in equation 2 ) can be computed as $\sum_{j=0}^{l} \delta_{j} /\left(1-\sum_{j=1}^{l} \phi_{j}\right)$.
} 
Equation (2) can also be enhanced with the addition of two types of asymmetries:

a.) Size asymmetry: the speed of adjustment to equilibrium may depend on the size of the deviation: the higher the deviation from equilibrium the quicker the adjustment.

b.) Sign asymmetry: first, the speed of adjustment differs depending on whether the deviation occurs above or below equilibrium. Second, sign asymmetry may be also interpreted in terms of the direction of changes in the key policy rate as a decrease in the policy rate may have a different impact on the pass-through than an increase in the policy rate.

There are three main strands in the literature depicted in Figure 2, which relate to the choice of the explanatory interest rate variable in equations (2) to (4). One strand tests how market interest rates are transmitted into retail bank interest rates of comparable maturity. This approach is termed the cost of funds approach (deBondt, 2002).

A second strand directly tests the impact of changes in the interest rate controlled by monetary policy on retail rates. Sander and Kleimeier (2004) call this as the monetary policy approach.

A third unifying approach includes two stages: a.) the pass-through from monetary policy rate to market rates $\left(i^{M P} \rightarrow i^{M}\right)$ and b. $)$ the transmission from market rates to retail rates $\left(i^{M} \rightarrow i^{B}\right)$. These two stages can be incorporated into an ECM representation as in equation (6) (Berstein and Fuentes, 2003 and deBondt et al. 2003):

$\Delta i_{t}^{B}=\alpha_{0}+\rho\left(i_{t-1}^{B}-\mu-\beta i_{t-1}^{M}-\beta i_{t-1}^{M P}\right)+\sum_{j=0}^{l} \delta_{j} \Delta i_{t-j}^{M}+\sum_{j=0}^{l} \gamma_{j} \Delta i_{t-j}^{M P}+\sum_{j=1}^{l} \phi_{j} \Delta i_{t-j}^{B}+\epsilon_{t}$

However, the interpretation of equation (6) in a single-equation setting becomes difficult when the series are found to be cointegrated. In this kind of set up it is more appropriate to test separately for the existence of two potential cointegration relationships $\left(i^{M P} \rightarrow i^{M} ; i^{M} \rightarrow i^{B}\right)$ using the methods of Johansen (1995).

Figure 2. The Transmission between Interest Rates

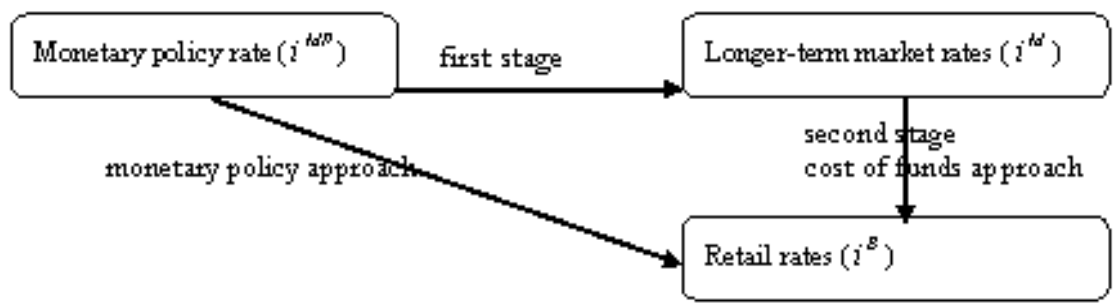


One difficulty with the transmission between interest rates that deserves special mention is that the first stage between monetary policy rates and longerterm market rates, captured directly by the first stage of the unifying approach and indirectly by the monetary policy approach, measures inherently the term structure. As already noted, the term structure crucially hinges on how expectations are formed about future inflation and monetary policy's reaction to inflation. Consequently, the term structure may change over time and may differ between countries. For a given country, changes in the term structure may indicate changes in inflation expectations or the progress of disinflation. Across countries, differences in the term structure may stem from heterogeneity about the credibility of monetary policy or weights/preferences given to fighting inflation (trade-off between inflation and output stabilisation).

There is a large literature aimed at investigating the interest rate passthrough for euro area countries. DeBondt (2002) and Kleimeier and Sander (2002) summarise the key findings of this empirical literature:

1. Bank retail interest rates adjust sluggishly in the short run, especially overnight and short-term deposit rates and rates on consumer loans. At the same time, there is some evidence regarding a possible complete pass-through in the long-run, in particular for short-term corporate loan rates and perhaps also for housing/mortgage rates. It seems that long-run pass-through is incomplete for (short-term) deposit rates and consumer loans.

2. However, large amounts of heterogeneity exists both for short-term adjustments and for long-run pass-through across the retail interest rate landscape.

3. Ample evidence is found in favour of asymmetric adjustment in the passthrough process. Nevertheless, no systematic pattern emerges.

4. Although economies of the euro area exhibit substantial heterogeneity with regard to the interest rate pass-through, it appears that the passthrough became faster and more homogeneous after the introduction of the euro. DeBondt (2002) suggests this was due to increased competition, lower switching costs and costs associated with asymmetric information and a rise in the interest rate elasticity of demand for banking products.

\subsubsection{Empirical Results for the CEECs}

Table 1 summarises the empirical studies carried out for transition economies. It is worth noting the country coverage for different segments of the interest rate pass-through is unbalanced and there may be concerns relating to the quality of the data series ${ }^{5}$. Nonetheless, some general conclusions can be made. First, it appears that there is a very high or complete pass-through from the key monetary policy rate to short-term money market rates. The pass-through from money market rates towards market interest rates of shorter maturity also turns out to be very high, whereas pass-through to long-term market rates is unstable mainly because of the change in the yield curve due to successful disinflationary

\footnotetext{
${ }^{5}$ Notwithstanding changes in the definition of interest rate series, some authors (Sander and Kleimeier, 2004) use very long series spanning over 10 years in some cases, which raises concerns on how to interpret the results.
} 
policies. This implies that the pass-through from the policy rate to retail rates occurs not via long-term market rates but rather via shorter-term market rates.

All studies use the one-stage monetary policy approach when studying the pass-through from market rates to retail interest rates. The results turn out to be very similar to the findings for the euro area.

1. The most complete pass-through is typically found for short-term corporate lending rates, followed by long-term corporate loan rates. The lowest average pass-through is observed for consumer loans. However, it tends to be higher for the Baltic States and particularly low for the Czech Republic and Slovakia. For Hungary and Poland, the range is rather large. In general, interest rate charged for new loans tend to react stronger to market conditions in the long run as compared to old loans. However, somewhat surprisingly, the opposite holds true for Romania.

2. The pass-through to deposit rates is less complete, with an average longrun pass-through coefficient of 0.72 for short-term deposits and 0.69 for longterm deposits. It appears, therefore, that the remuneration of current accounts and saving accounts incorporates a very low fraction of changes in the market rates. However, the pass-through of time deposits increases for higher maturities. Another, and perhaps surprising, observation is that there is no systematic difference between the long-run pass-through for interest rates on household and corporate deposits for Hungary and Poland. In contrast, changes in market rates are much less transmitted into corporate than into household deposit rates in Estonia and Latvia.

3. There is substantial cross-country heterogeneity for the long-run passthrough $^{6}$. Indeed, heterogeneity is even considerable for the same market in the same country. Consider, for example, mortgage rates for Lithuania where the pass-through is complete for the one-year rates and is nearly nil for fiveyear rates. Sander and Kleimeier (2004b) provide some quantitative support for this view by regressing the estimated pass-through coefficients on country and market (loans, deposits) dummies. The country dummies turn out to be significant. The market dummies confirm that short-term and long-term loan rates are higher and their reaction is swifter, especially when compared to saving and current accounts. They also find that the long-run pass-through for corporate loans is pretty homogeneous. Differences are, however, to be observed for the speed of adjustment. Égert, Crespo-Cuaresma and Reininger (2006) also provide evidence for large heterogeneity across countries and market segments. They also show that for a number of time series for which error correction models are estimated in the literature are not cointegrated and the regressions run for first differenced data provide with lower pass-through coefficient estimates.

A major difference for CEECs compared to the euro area countries is the weaker evidence in favour of asymmetry in the adjustment process. Sander and Kleimeier (2004b) conclude that the pass-through process exhibits less

\footnotetext{
${ }^{6}$ It is not always clear whether the interest rate series used under the heading "longrun interest rates" are eventually fixed or variables rates for long-run loans or deposits. However, whatever the composition is, the results indicate how a given composition reacts to changes in the base or market rates.
} 
asymmetry in the transition economies. This statement is backed by results reported in Crespo-Cuaresma, Égert and Reininger (2004) and Chmielewski (2003). Nonetheless, Opiela (1999) finds some asymmetries for Polish bank level data from 1994 to 1998, and Horváth, Krekó and Naszódi (2004) for a more recent period for Hungarian deposit and loan rates. Égert, Crespo-Cuaresma and Reininger (2006) find an increase in asymmetry over time even though the share remains low and no clear pattern seems to emerge with regard to any specific country or interest rate series.

Another important feature of interest rate pass-through in Central and Eastern Europe is that in general, both the contemporaneous and long-run passthrough is found to increase over time and the mean adjustment lag to full pass-through to decrease as more recent data can be used (Crespo-Cuaresma, Égert and Reininger., 2004; Horváth, Krekó and Naszódi, 2004; and Sander and Kleimeier, 2004b) ${ }^{7}$. However, Égert, Crespo-Cuaresma and Reininger (2006) are more sceptical about this and show that the pass-through was slowing down in the last couple of years in the CEE-5.

\subsubsection{What Are the Main Factors Affecting the Interest Rate Pass- Through in the CEECs?}

A number of researchers have attempted to analyse the factor, or factors, which may lie behind the size and speed of the pass-through. Three approaches have been taken. The first consists of estimating a time series pass-through equation, such as equations (2) to (5), and including variables such as market concentration. For example, Wróbel and Pawlowska (2002) introduce a monthly indicator measuring market concentration for deposits and loans (Herfindahl-Hirschman index ${ }^{8}$ ) in Poland and show that an increase in concentration reduces the passthrough for lending rates (as expected) but increases it for deposit rates. Kot (2004) employs a different measure for competition. He argues that if competition is strong (that is, banks are price takers), the interest rate elasticity of the demand for products of individual banks is much larger than the interest rate elasticity of aggregate demand for bank products. Conversely, if banks have market power and therefore can influence interest rates, the interest rate elasticity at the individual and at the aggregate level will be closer to one another. The empirical assessment of the elasticities shows that consumer credit markets are more competitive in Hungary and in Poland than those in the euro area and the degree of competition is the lowest in the Czech Republic. The connection between competition and pass-through is not particularly strong given that the interest-rate pass-through for consumer credits in Hungary and Poland is comparable to that in the euro area, despite harsher competition, while it is lower in the Czech Republic.

\footnotetext{
${ }^{7}$ Világi and Vincze (1998) report very sluggish short-run adjustment and very low (0.1) long-run pass-through from 30-day and 90-day T-bill rates towards rates on new corporate loans and short-term corporate deposits for Hungary between 1991 and 1994 .

${ }^{8}$ Alternatively, market concentration could also be measured as the share of the three or five biggest banks in terms of loans or deposits in total loans or deposits.
} 
A second group of papers exploits the cross-sectional dimension of the data by first estimating pass-through coefficients using time series for an array of countries and markets and then by regressing it on a number of explanatory variables, such as macroeconomic variables and variables related to the structure of the financial sector. Sander and Kleimeier (2004b) adopt this approach. Their results indicate that of the macroeconomic variables, while GDP growth and financial depth do not affect the speed and the size of the pass-through, higher inflation is associated with a more pronounced pass-through and money market volatility decreases the pass-through ${ }^{9}$. As far as variables measuring the structural features of the financial sectors, less concentration, less bad loans (a healthier banking sector) and more foreign participation tend to be associated with higher and faster pass-through. This result holds for loans as well as for deposits.

This approach can be extended to bank level data. In such a setting, passthrough coefficients are estimated for individual banks, and, in the second stage are regressed on bank-specific features. Opiela (1999) uses this option and shows that for the period from 1994 to 1998, the pass-through of 37 Polish banks depends on the ownership (involvement of the State), the share of bad loans and the degree of capitalisation. In particular, it is demonstrated that interest rates of State-owned banks respond strongly when interest rates fall, while these are banks loaded with bad loans, which pass on changes in market conditions quicker to retail interest rates during periods of rising interest rates.

A third way of proceeding involves combining the time series and crosssectional dimensions of the bank-level data by analysing how interest rates of individual banks react to monetary policy steps and how these steps interact with bank specific characteristics has been investigated in a panel setting. Berstein and Fuentes (2003) propose estimating a panel model including an interaction term with the share of bad loans, the bank's size (in terms of total loans, SIZE) and the share of loans to households (as a proxy for the type of customer, $\mathrm{HH}) \cdot{ }^{10}$.

We now turn to the empirical evidence for the transition economies. Horváth et al. (2004) investigate whether interest rate pass-through is heterogeneous for 25 Hungarian banks and find for the period from 2001 to 2004 that the pass-through was homogenous for corporate loan and deposit rates. Várhegyi (2003) examines interest rate pass-through from money market rates to household deposit rates for a similar dataset (11 Hungarian banks) and sample period

\footnotetext{
${ }^{9}$ This stands in contrast with Horváth et al. (2004) who find that higher money market volatility increases the speed of adjustment. 10

$i_{i, t}^{B}=\alpha_{i}+\sum_{j=0}^{l} \delta_{j} i_{i, t-j}^{M} B A D L_{i, t-j}+\sum_{j=0}^{l} \delta_{j} i_{i, t-j}^{M} H H_{i, t-j}+\sum_{j=0}^{l} \delta_{j} i_{i, t-j}^{M} S I Z E_{i, t-j}+\sum_{j=1}^{l} \phi_{j} i_{i, t-j}^{B}+\epsilon_{i, t}$

where BADL denotes bad loands, SIZE is the bank's size (in terms of total loans, SIZE) and HH refers to the share of loans to households (as a proxy for the type of customer). Weth (2002) estimates bivariate (market rate and retail rate) panel error correction models for different classes of banks.
} 
(2000-2003). While the pass-through is incomplete in the long-run for all banks, some heterogeneity is uncovered for individual banks.

Chmielewski (2004) goes a step beyond studying pass-through at the bank level and estimates the model used by Weth (2002) for two groups of Polish banks as a function of whether they are good or bad in terms of: i.) the share of classified loans; ii.) capital adequacy ratio; and iii.) profitability captured by returns on assets (ROA). Perhaps, not surprisingly, more profitable banks adjust household deposit rates for longer maturities and for corporate loan rates faster than less profitable banks. Also, banks with more bad loans are quicker in adjusting their lending rates and slower in doing so for deposit rate. Finally, better capitalised banks turn out to react less quickly to market conditions than less capitalised banks.

To summarise, higher concentration of the banking sector, higher profitability and capitalisation of banks typically make banks less receptive in adjusting their retail rates to the market/policy rates, and hence dampen the interest rate pass-through. However, this general finding is in conflict with the result that the ownership structure, especially the involvement of foreigners in the banking sector may enhance the interest rate pass-through given that more foreign participation leads to higher concentration, and foreign-owned banks tend to be more profitable and better capitalised. 
Table 1. Long-Run Interest Rate Pass-Through Estimates for the CEECs

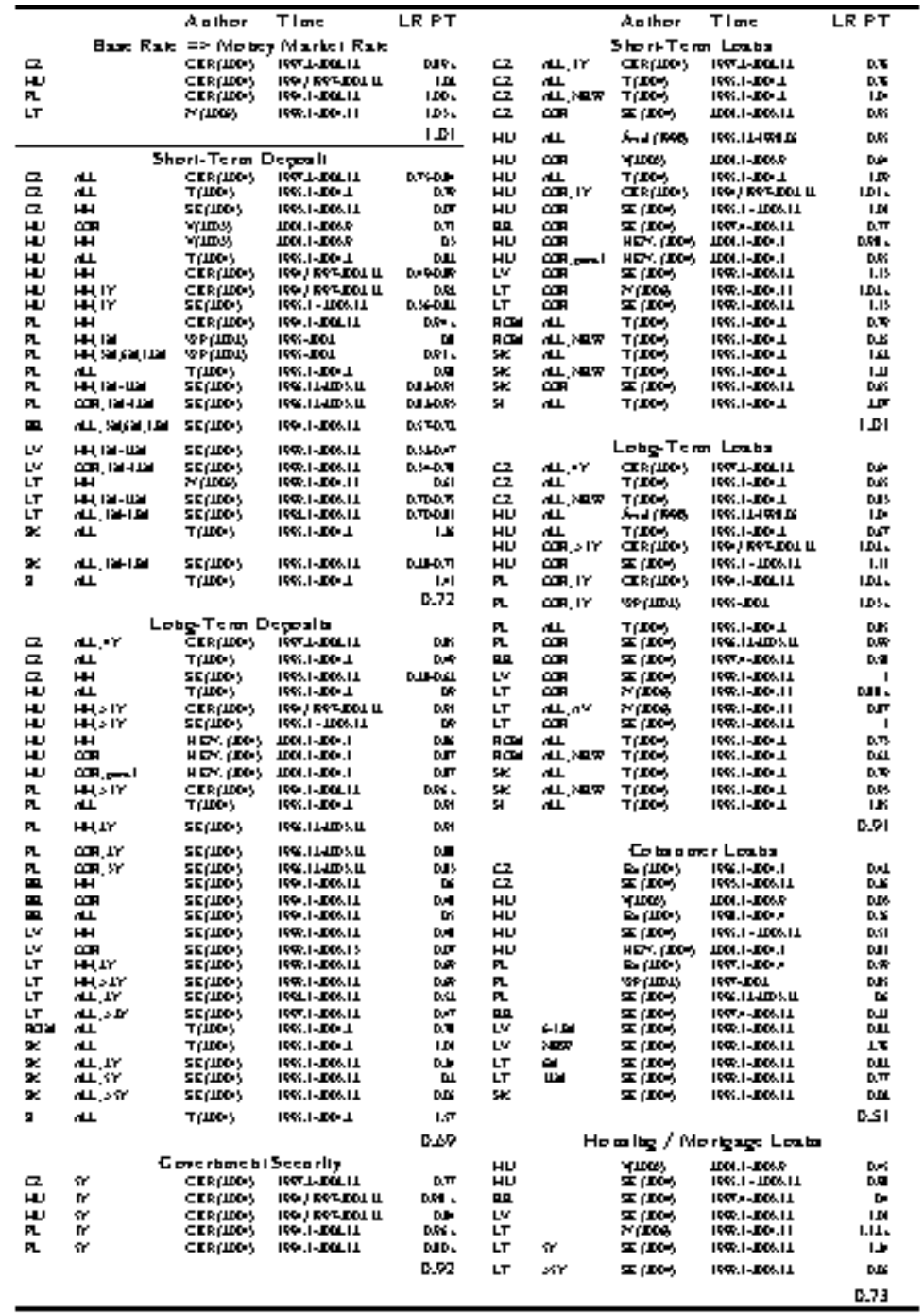

Notes: CZ, EE, HU, LV, LT, PL, ROM, SK and SI refer to the Czech Republic, Estonia, Hungary, Latvia, Lithuania, Poland, Romania, Slovakia and Slovenia. HH and COR stand for data series for households and for the corporate sector, while ALL is the aggregated series. NEW indicates interest rate series for new loans/deposits, and the figures after ALL, HH and COR may indicate the precise maturity. CER(2004), HKN (2004), N(2005), SK(2004), $\mathrm{T}(2004), \mathrm{V}(2003)$ and $\mathrm{WP}(2002)$ are Crespo-Cuaresma et al. (2004), Horváth et al. (2004), Nickisch (2005), Sander and Kleimeier (2004), Tieman (2004), Várhegyi (2003) and Wróbel and Pawlowska (2002). 


\subsection{Second Stage: The Monetary Channel}

As we have seen, the first stage of the monetary transmission concerns interest rate interactions. In what may be thought of as a second stage, the issue concerns how nominal interest rates impinge on the real sector. Price stickiness and rational expectations ensure that an innovation in short-term nominal interest rates will lead to moves in both short-term and long-term real interest rates. Given that real interest rate movements reflect changes in the cost of capital, corporate investment spending will be affected. Since they also have a substantial investment component, spending on housing and durable goods will also be sensitive to real interest rates. Of course, changes in interest rates entail two conflicting effects. A rise in interest rate increases the income of holders of interest bearing assets (income effect), which can be offset by higher interest rates favouring savings instead of consumption (substitution effect). Changes in investment, housing and durable good spending, i.e. global demand will eventually cause changes in output.

There are few recent empirical studies investigating this issue. One of them is Chatelain et al. (2001) who estimate the sensitivity of manufacturing firms' investment demand to changes in the user cost of capital (and in sales and cash-flow). The empirical evidence based on large micro panels indicates that investment demand in France, Germany, Italy and Spain is sensitive to the user cost of capital. This gives credit to the money channel to be at work in these countries. Similar results are reported in Kátay and Wolf (2004) for the case of Hungary. Kiss and Vadas (2005) investigate the Hungarian mortgage market and show that changes in mortgage interest rates have only a limited influence on disposable income (income effect) mainly because of institutional factors (the government subsidy scheme and the dominitation of fixed noncallable mortgages).

\section{Credit Channel}

We now turn to the credit channel which is clearly linked to the first stage of the interest rate channel, i.e. the interest rate pass-through. According to Bernanke and Blinder (1988), the traditional interest rate channel performs poorly as changes in the long-term real interest rate, as a measure of the cost of capital, appear only weakly related to changes in global demand and thereby fail to explain the amplification effect of short-term interest rates on output. Given this, they extend the transmission mechanism by introducing the credit channel, which, they argue, is an enhancement channel that amplifies the interest rate channel. The credit channel can be decomposed into two distinct channels: 1) the bank lending channel and 2) the broad lending channel (also termed balance sheet channel or financial accelerator), which are dealt with subsequently in what follows. ${ }^{11}$.

\footnotetext{
${ }^{11} \mathrm{~A}$ detailed overview of the theoretical and empirical literature related to the bank lending channel can be found in Kierzenkowski (2004).
} 


\subsection{Bank Lending Channel}

The bank lending channel can be formally modelled by introducing credit into the product markets in the traditional IS-LM setup (Bernanke and Blinder, 1988), where the IS curve is replaced by the credit-commodity (CC) curve, to produce the CC-LM model. Central to the bank lending channel is the imperfect substitutability between credits and other financial assets in the banks' balance sheet on the one hand, and that between bank credits and other forms of financing on firms' balance sheet, on the other, which makes it possible for monetary policy to affect economic activity in two stages.

Imperfect substitution in banks' assets ensures that a tightening (loosening) of monetary policy brings about a contraction (expansion) in banks' credit supply (the first stage). When facing a decrease in liquidity ${ }^{12}$, banks decrease their credit supply instead of selling bonds they possess because they have a desired level of liquidity to face, for instance, unexpected deposit withdrawals. Alternatively, banks could also issue bonds or collect deposits from households or from the corporate sector rather than decrease credit. However, the ability of some banks to borrow from financial markets may be limited by financial market imperfections, such as adverse selection and moral hazard (imperfect substitutability between credits/bonds on the asset side and bonds/deposits on the liability side).

For monetary policy to be transmitted to the real economy, it is necessary that some firms are not capable of substituting bank credit to other forms of external funding on the capital markets (imperfect substitutability on the liability side of firms ${ }^{13}$ ). In such a case, once credit supply decreased (increased) investment spending will be cut back because of the lack of external financial resources (second stage).

Underlying the analysis of Bernanke and Blinder are the hypotheses that: a.) the income elasticities of credit demand and money demand are the same; and b.) the interest elasticity of credit demand equals that of credit supply. Kierzenkowski (2005a, 2005b) has recently shown that relaxing, in particular, hypothesis b.) implies that the bank lending channel need not lead automatically to an amplification in this framework and can, importantly, also cause attenuation.

\footnotetext{
${ }^{12}$ Bernanke and Blinder assume that the central bank controls the base money and a tightening (loosening) of the monetary policy decreases (increases) the liquidity of the banking sector. Alternatively, it is also possible to model monetary policy, which controls the interest rate. A simple way is to assume the stability of money demand function, through which a change in the interest rate affect monetary aggregates. A more elaborate way is to introduce some kind of monetary policy reaction function, which links the policy rate to other variables.

${ }^{13}$ Central to this analysis is the special role banks play in the presence of asymmetric information, which is widely acknowledged since the seminar articles of Akerlof (1970) and Fama (1985). In addition to reducing transaction costs (cost of searching, verification and monitoring costs) and transforming maturity, banks are in a good position to reduce problems related to asymmetric information (adverse selection and moral hazard), i.e. transforming risk. For a recent general overview on market imperfections, see DeGennaro (2005).
} 


\subsection{Bank Lending Channel ${ }^{14}$}

Imperfect substitution in banks' assets and in firms' liabilities, the cornerstone of the Bernanke-Blinder model, is not necessarily the case. In accordance with Kashyap, Stein and Wilcox (1993), while small banks cannot borrow on financial markets, larger banks definitely can. Similarly, larger firms have access to capital markets and can escape bank credit supply contraction. This leads us to a broader concept, namely to the broad lending channel. The imperfect substitution no longer exists between bank credits and other financing but between external and internal financing ${ }^{15}$ where the cost of external financing is higher with the external financing premium, which in turn, primarily depends on net wealth ${ }^{16}$ serving as collateral for loans and credits. The higher the net wealth of the borrower, the lower the external risk premium is mainly because: a.) higher (expected future) revenues enable one to finance investment internally; and b.) more valuable collaterals increase safety of the lender, thus decreasing both moral hazard and adverse selection. Consequently, any change in net wealth generated directly or indirectly by monetary policy will be reflected in the risk premium and thus in the capacity to borrow. Monetary policy can influence net wealth, via the interest rate, asset price and exchange rate channels described earlier:

1.) Income effect (or cash-flow channel): an increase (decrease) in short term interest rates increases (decreases) the cost of servicing short-term and floating-rate debt, which reduces (raises) cash-flow and thus net wealth

2.) Debt channel: unexpected rise in inflation makes the real costs of servicing the debt lower, the terms of which are determined in nominal terms.

3.) Asset price channel 1: an increase (decrease) in short term interest rates lowers (increases) the price of equity, bonds and housing, which thus directly influences net wealth.

4.) Asset price channel 2: Wealth and liquidity effect of households: monetary policy can impact on household' borrowing capacity as described in the asset price channel ${ }^{17}$

5.) Exchange rate channel: if assets or credits/loans are denominated in foreign currency, nominal exchange rate developments can increase (decrease) their value in domestic currency, which also exerts an influence on borrowing capacity.

\footnotetext{
${ }^{14}$ This channel is also termed financial accelerator, balance sheet channel or the borrower net worth channel.

${ }^{15}$ This contrasts with the Modiglian and Miller theorem on the neutrality of internal and external funding. Note that in the broad lending channel, banks play no special role any more as compared to the bank lending channel.

${ }^{16}$ Net worth or net assets is obtained as total assets minus total liabilities.

${ }^{17} \mathrm{It}$ is noteworthy that both the bank lending channel and the broad lending channel applies not only to the investment of the non-financial corporate sector but also to household spending. On the one hand, a fall in credit supply related to consumption or housing decreases credit to households, which are particularly bank dependent. On the other hand, a decrease in the price of assets (bonds and equities) and housing hold by households and a fall in income reduces the value of households' collaterals for loans.
} 
6.)Second-round effects: If spending of households or firms falls as a consequence of monetary policy action, other firms revenue also falls, leading to a decrease in net wealth as a function of rigidities on the cost side.

Therefore, decreasing (increasing) net wealth by lowering both equity and housing prices and cash-flows (income effect) results in a decreased (improved) capacity of obtaining loans because of the aforementioned imperfections of financial markets (adverse selection and moral hazard), which provoke a decrease (increase) in investment and consumption spendings.

It is worth mentioning that the broad lending channel conveys not only the effects of monetary policy because not only changes in monetary conditions but also alterations of other exogenous factors may lead to changes in the balance sheet of both household.

\subsection{Trade Credit and the Bank Lending Channel}

Trade credit, which is usually created if a firm delays payment to its supplier, is thought to be more expensive than bank credit. However, this holds true only during "normal" times. Because the terms of trade credit are fairly stable over time, it may become cheaper relative to bank credit in the wake of a monetary policy tightening. In fact, trade credit may become the only external source of financing for firms with no credit rating and thus access to capital markets during credit rationing. As a results, if firms also have access to trade credit, instead of only bank and market financing, firms hit by external financing constraint after a monetary tightening can potentially avoid the squeeze by increasing trade credit (see e.g. Mateut, 2004).

\subsection{The Bank Capital Channel ${ }^{18}$}

A number of recent papers put strong emphasis on the prominent role bank equity capital plays in the monetary transmission mechanism - also called the bank capital channel - through which monetary policy influences credit supply. The standard credit channel literature has been criticised because it assumes that the central bank affects loan supply by altering the required reserves. Chmielewski (2005) stresses that reserve requirements may be inappropriate as, for instance, using the interest rate as the main policy instrument, inflation targeting central banks may not be able to control required reserves. Yet loan supply can be strongly affected via changes in bank capital requirements. This channel has been formalised, for instance, by Van den Heuvel (2002). For the bank capital channel to be operational, the following assumptions need to apply:

a.) it is costly for banks to raise equity.

b.) banks assume an interest rate risk with the maturity of their credit being higher than that of their deposits.

c.) capital regulations influence banks' credit supply.

\footnotetext{
${ }^{18}$ Although the literature typically views the bank capital channel as a separate channel from the credit channel, because its implications are very close to the credit channel, we put it in the same basket for the sake of convenience.
} 
The mechanism works as follows. A rise in interest rates, triggered by monetary policy action, increases the cost of financing (deposits), while leaving the remuneration of banks' assets unchanged due to the maturity mismatch. This induces a fall in bank capital. In the event that the bank is close to the minimum capital requirement prescribed by law, it is obliged to decrease the supply of loans as raising equity is costly.

According to van den Heuvel (2002), banks with low capital react slowly but then in an amplified fashion to monetary policy shocks. Even banks with high capital can adjust their loan portfolio if they expect trouble in meeting capital requirement in the future or, as emphasised by Chmielewski (2005), they intend to maintain the same level of riskiness of their loan portfolio.

In a banking system where banks possess a considerable amount of corporate equity like in Germany, any change to the price of corporate equity will have an direct impact on banks' profit, capital and consequently on their credit supply (Markovic, 2004).

Markovic (2004) distinguishes three sub-channels of the bank capital channel:

a. the default risk channel is related to the eventuality that the bank defaults on its equity, which, in turn, depends on the default risk of firms.

b. the adjustment cost channel reflects asymmetric information between the bank and its shareholders and the fact that the elimination of it is costly.

c. the capital loss channel

Markovic (2004) argues that the capital cost channel is likely to gain importance in the occurrence of large shocks to the bank capital, such as writing-off of non-performing loans or changes in the regulatory framework.

\subsection{Trojan Horses Affecting the Credit Channel}

There are a number of potential sources which could counteract the transmission mechanism of the bank lending channel in its first and second stages and the internal-external financing constraint crucial for the broad lending channel.

\subsubsection{Factors Interfering with the First Stage of the Bank Lending Channel}

a.) Multi-bank holding networks are conducive for the creation of internal capital markets, from which affiliated banks can benefit even though external resources of financing have dried up. This is especially important for small banks as, contrary to the basic assumption of the Bernanke and Blinder model, they can insulate their loan supply from monetary policy shocks (Ashkraft, 2005). This implies that a smaller number of banks are subject to imperfect substitutability on the asset side. In extreme cases where all banks belong to banking networks, such as is the case in Germany or in Finland, the bank lending channel is completely disabled (Ehrmann and Worms, 2001). Gambacorta (2005) also sheds light on network effects for Italian banks. In the event that banks have foreign owners, they belong to a larger network, and the same argument applies as before. 
b.) An overall well-capitalised banking system may be less conducive for the bank capital channel.

c.) A high degree of concentration of the banking sector implies the absence of small banks. As large banks have easier access to alternative external financing, they can buffer their credit supply from monetary policy shocks (Adams and Amel, 2005).

An important point has to be made here. There is a crucial interaction between the credit channel and the interest rate pass-through. It appears that more concentrated markets are less vulnerable to the credit channel. At the same time, banks on these markets do not tend to react proportionately to interest rate changes. So, they cushion the effect of monetary policy not only for quantities but also for prices, and this weakens the overall impact of monetary policy on the real economy.

d.) The maturity structure of loans and the trade-off between fixed or variable interest rates can very much determine the reaction of loan supply to monetary policy actions. The shorter the maturity structure, the more immediate the pass-through from monetary policy to loan supply is supposed to be (Ehrmann et al. 2001).

e.) Relationship lending, i.e. the phenomenon of the Hausbank, may lead to loan commitments, which could help disconnect to some extent loan supply from monetary policy (Ehrmann et al. 2001).

f.) The government's involvement in the banking sector either as owner or via public guarantees can partially offset the effects of monetary policy on loan supply (Ehrmann et al. 2001).

g.) If loans to the private sector are denominated in foreign currency, then domestic interest movements have only a limited effect on the supply of and demand for loans since their price is given by the foreign interest rate plus the exchange rate premium ${ }^{19}$. A contracting monetary policy manifesting in higher interest rates would have an opposite effect than desired as it would cause an appreciation of the exchange rate, which, in turn, leads to a shrunk of the FX denominated loan in domestic currency terms. The higher the share FX denominated loans in total lending, the lower the direct impact of domestic monetary policy on domestic lending and borrowing activity.

\subsubsection{Factors Interfering with the Second Stage of the Bank Lending Channel}

In addition to trade credit and other sorts of inter-company loans, there exists a number of other factors which may potentially break down the second stage of the bank lending channel:

a.) A potential attenuation of both the bank lending and the broad lending channel can occur if firms are able to insulate themselves from short-term shocks in bank or external borrowing via altering capacity utilisation, if financial constraints are anticipated in advance (Wang, 2001).

\footnotetext{
${ }^{19}$ Plus default risk, but this is also contained in the domestic interest rate
} 
b.) Government involvement may also mean soft budget constraint for firms (Kornai, Maskin and Roland, 2003). This issue may be especially important for transition economies, where the hardening of the budget constraint may vary in function of how advanced the process of privatisation of both the nonfinancial corporate and the banking sectors, the introduction of bankruptcy laws, accounting standards and Western corporate governance are. In particular, soft budget may be due to open subsidies or implicit subsidies (tolerance of tax arrears, tax relief and tax concessions) from the government or easy access to new credits from state-owned banks. A soft budget constraint is still present at least in some sectors of less advanced transition countries such as Bulgaria, Croatia and Romania, let alone the CIS countries (see Croitoru and Schaffer (2002) for Romania). However, one may also argue that a soft budget constraint mostly concern larger firms, which would be otherwise less subject to the credit channel.

c.) If small firms' contribution to output is low, or even better, if only a small fraction of (small) firms relies on bank lending, the macroeconomic impact of the bank lending channel will be negligible ${ }^{20}$.

d.) If the distribution of small firms differs across sectors, the impact of monetary policy acting via the credit channel may be heterogeneous across sectors. In particular, it is observed that the share of small firms in output is considerably larger in the non-tradable than in the tradable sector (Tornell and Westernmann, 2002). Hence, the credit channel may be more important for the non-tradable sector ${ }^{21}$.

\subsection{Empirical Evidence for Industrialised Countries}

A large number of papers has investigated the relevance of the credit channel for the US and, more, recently also for Europe. The main preoccupation of this literature has been to distinguish between the traditional interest channel and the credit channel, in particular the bank lending channel.

\subsubsection{Macroeconomic Studies}

Focusing on Spread Data One prediction of the Bernanke and Blinder model is a non-zero spread between interest rates on credit and bonds. In particular, if there exists a bank lending channel, a restrictive monetary policy will lead to an increase in this spread, while monetary expansion causes the spread to decrease $^{22}$. This implication is widely exploited in empirical investigations. For

\footnotetext{
${ }^{20}$ The capitalisation and the liquidity position of the firms are also important for the functionining of the credit channel. Altough large firms may be also badly capitalised and less liquid, small firms usually are less capitalised and less liquid as compared to large firms.

${ }^{21}$ It is interesting to note that the vast majority of empirical studies concentrate on the open sector, i.e. manufacturing. Hence, they may miss the point.

${ }^{22}$ It should be noted that the credit - treasury bill interest spread seems a good indicator in tracking down amplification and attenuation regimes such as set out in Kierzenkowski (2005a,b).
} 
instance, Bernanke and Gertler (1995) and Kashyap, Stein and Wilcox (1994) document the amplification of the spread, constructed using short-term rates, by changes in the stance of monetary policy using data for the 1970s and 1980s. However, as noted in Bernanke and Gertler (1995), it is difficult, in practice, to separate the bank lending and the broad lending channels on the basis of the spread given that the broad lending channel would also predict an amplification of the spread, which, in this context, would reflect the difference between the costs of external to internal financing. In contrast, Miron, Romer and Weil (1994) cannot confirm this amplification for secular US data going back to 1896. Kierzenkowski (2004) argues that the absence of amplification is due to the fact that banks aim to smooth the effects of changes in the policy rate on the lending rates. This point leads us back to the issue of interest rate pass-through.

VAR-based Studies Another way of studying the importance of the credit channel is to use impulse response functions obtained from VAR models. Bernanke and Blinder (1992) use a VAR-based approach to analyse the reaction of bank loans, deposits and bonds to a monetary policy tightening. for the US.They demonstrate that bank deposits decline immediately in the aftermath of a monetary policy shock, whereas loans start to decrease only with a delay of 6 to 9 months. Two years after the monetary shock, bonds appear to recover completely, while deposits and loans stabilise at a lower level.

The reason why bank lending reacts with such a lag to changes in the stance of monetary policy is that banks can commit themselves to maintain a given credit line for a given period for their clients (loan commitments), which is left unchanged until expiry. Morgan (1998) demonstrates by means of impulse response functions that "committed" loans are not much influenced by monetary policy actions.

Gertler and Gilchrist (1993) make a step further by decomposing loans into commercial \& industrial (C\&I) loans, housing credit and short-term credit. $>$ From their results it seems that housing and short-term credit contrast and C\&I loans are unaffected in the wake of a monetary tightening.

Money or Credit Aggregates as Leading Indicator of Economic Activity? Another line of research, initiated by King (1986), aimed at separating the interest rate and credit channels in order to determine if monetary or credit aggregate is a better indicator of future output. The unanimous verdict of King (1986), Romer and Romer (1990) and Ramey (1993) is that monetary aggregates better predict future economic activity than credit aggregates, which is a strong piece of evidence against the bank lending channel.

Identification Issues There are two major caveats regarding the use of aggregate macroeconomic series worth mentioning at this point. First, it is difficult to distinguish between the effects of the traditional interest rate channel and the credit channel because money and credit aggregates are strongly correlated, given the construction of bank balance sheets. One solution to circumvent this 
problem using data disaggregated at the sectoral level. Escriva and Haldale (1994) and Dale and Haldale (1995) argue that this correlation breaks down at the sectoral level as banks can reallocate credit across sectors. Using data for British and Spanish households and the non-financial corporate sector, they shed light on the fact that after a hike in the monetary policy rate, loans to households decline first, followed by a drop in output (retail sales for households and industrial production for firms), and, at a later stage, by a decline in loans to the corporate sector. By contrast, a fall in money aggregates happens before the contraction of industrial production. The implication of these findings is that the credit channel is at work for households but not for firms for which the interest rate channel is crucial in the transmission of the effects of monetary policy. Kakes (1998) extends this analysis to Dutch data by introducing short- and long-term credits. It transpires that only long-term loans to households record a decrease after a monetary tightening. The credit channel does not appear, however, to be decisive because household consumption does not alter ${ }^{23}$.

Ramey (1993) proposes an alternative method disentangling the money and credit channels. Her method consists in first estimating a comprehensive VAR including both credit and monetary aggregates. Subsequently, the interest rate channel is switched off by restricting the coefficient on a monetary policy shock in the equation for monetary aggregates to zero. The application of this method to US data indicates the lack of any response of output to monetary policy shocks when the interest rate channel is cancelled.

The second major identification issue relates to the question of whether changes in the loan series occur as a result of a variation of the loan supply or because monetary policy affects output through the interest channel, which, in turn, is reflected in an alteration of credit demand. Driscoll (2004) considers the US as an ensemble of small open economies with a fixed exchange rate regime. The implication is that the interest channel is deactivated as the FED only responds to country-level shocks as opposed to state-specific shocks, so statespecific money demand shocks results in state-specific shock in loan supply if there is bank lending channel. He shows that the bank lending channel breaks down at its second stage as loan supply is affected by money demand (the first stage of the bank lending channel) but loan supply has no significant effect on output (the second stage of the bank lending channel). That is, firms are not bank dependent.

The "Mix" Variable The second identification issue can also be addressed by the use of the "mix" variable. The so-called "mix" variable is designed as an attempt to overcome the identification problem encountered when using aggregate macroeconomic series. Using the "mix" variable capturing changes in bank lending relative to total external financing (bank lending + commercial papers), Kashyap, Stein and Wilcox (1993) demonstrated that the "mix" variable decreased during periods of US monetary tightening, implying the decline

\footnotetext{
${ }^{23}$ Results also show that banks orchestrate a shift in loans from households to firms, which can be viewed as a flight to quality.
} 
in bank lending relative to other external resources and thus lending support to the bank lending channel. However, we cannot take this result at face value. As the amount of commercial papers is quasi zero for small firms, a drop in the "mix" would be in line with both the bank lending and the broad lending channel. Oliner and Rudebusch (1996) split US manufacturing firms into small and large firms and broadened the definition of non-bank external lending by adding loans from finance and insurance companies (a significant amount both for small and large firms). Their result indicates that the "mix" is unaffected for the two groups of firms and that all types of financing shift from small to large firms. This indeed supports the broad lending channel view instead. Kashyap, Stein and Wilcox (1996) responded by disaggregating their original mix variable along the lines of small and large firms, and found a significant - although somewhat less so than for aggregated data - decrease in the mix variable for large firms.

Combining the VAR methodology with the "mix" variable, Ludvigson (1998) presents econometric evidence for the existence of a bank lending channel for US automobile credit. Although an unanticipated monetary policy shock significantly changes the mix variable, and a change in the mix variable causes a variation in automobile consumption, he concludes that its quantitative effect on overall car sales is negligible.

\subsubsection{Studies Using Large Bank and Firm Level Panel Datasets}

The First Stage - Bank's Balance Sheet Micro-based bank and firm level panel data help to give more insight into the bank lending channel. Credit supply and credit demand can be separated from each other when focusing on balance sheet characteristics of banks or firms. Features of individual banks determine their capacity to supply credit, but these features are not connected to credit demand. Along the same lines, systematic differences in firms' characteristics may explain their diverging ability to absorb credit, without this being related to credit supply. This accounts for the recent surge of papers, which focus on the use of large bank and firm-level panels. One of the first and most cited papers is that of Kashyap and Stein (1995). They split banks into subgroups dependent on their size, measured in terms of total assets. They conjecture that the bank lending channel implies that small banks have limited access to market finance, and, for this reason, both loans and bonds will contract in their portfolios after a monetary policy shock. However, it turns out that only small banks' loans and not bonds decrease. They explain this by the fact that small banks accord loans over-proportionately to small firms, whose credit demand is procyclical. Hence, negative monetary policy shocks may change the business climate negatively through channels other than the credit channel, which yields a lower demand for credit from small businesses. Kashyap and Stein (2000) introduce, additionally, the liquidity position of banks by estimating the following equation for groups of banks of different size: ${ }^{24}$

\footnotetext{
${ }^{24}$ Kashyap and Stein (2000) also presented estimation results for a two-stage setup. However, they argue that their two-step method is likely to be over-parameterised.
} 
$\Delta L_{i t}=\sum_{j=1}^{4} \alpha \Delta L_{j i t-j}+\sum_{j=1}^{4} \beta_{j} M_{i t-j}+\sum_{j=1}^{4} \beta_{j} Y_{t-j}+C_{i t-1}\left(\phi+\sum_{j=1}^{4} \eta_{j} M_{i t-j}+\sum_{j=1}^{4} \kappa_{j} Y_{i t-j}\right)$

where $\Delta L_{i t}$ is the growth rate in loan supply for bank $i$ for period $t, M$ measures monetary policy, $Y$ is real output and $C$ denotes bank characteristics (e.g. the liquidity of banks $)^{25}$. The interaction between monetary policy and banks' characteristics are captured by $\sum_{j=1}^{4} \eta_{j}$. They find that small and less liquid banks are most responsive to monetary policy actions, which, they argue, is in line with the bank lending channel.

In a similar setup, Baum, Caglayan and Ozkan (2004) shed some light on the role of uncertainty of financial markets on bank lending behaviour. Using a variety of alternative measures for uncertainty, they show that increased uncertainty leads to higher credit supply, and this is independent of the bank size. At the same time, increased uncertainty with a low liquidity position results in a decline in loan supply albeit to a lesser extent than for banks with high liquidity, implying greater risk-taking by low-liquidity banks. An important finding is that the group of small banks, as defined in Kashyap and Stein (2000), is a heterogeneous group with respect to reactions to monetary policy actions, and this clearly downplays the importance of the bank lending channel in the US economy.

An increasing number of papers have provided firm empirical backing for the bank capital channel. Peek and Rosengren (1995), Thakor (1996), and Hancock and Wilcox (1998) demonstrated the importance of the introduction of new riskbased capital requirements, i.e. he Basle agreement on capital requirements in 1989 and 1992, during the 1990-92 credit crunch in the US economy. Using micro-level panel of banks, Kishan and Opiela (2000), for the US demonstrate that small banks with low-capital are most affected by contractionary monetary policy in their lending behaviour, be it commercial \& industrial, housing or household loans. Markovic (2004b) reaches similar conclusion for the UK.

As far as the euro area is concerned, Favero, Gavazzi and Flabbi (1999) provided some evidence against the bank lending channel in 1992, on the basis of large bank-level datasets for the four largest euro area countries, namely France, Germany, Italy and Spain. By estimating equation (8) for a cross-section of banks, it turns out that changes in reserves do not have any significant effect on loan growth in 1992 via the interaction with size and the liquidity position.

$$
L_{i}=\alpha+\sum_{j=1}^{10} \beta_{j} \cdot \text { DECILE }_{j} \cdot \Delta \text { reserves }_{i}+\sum_{j=1}^{10} \chi_{j} \cdot \text { DECILE }_{j} \cdot C_{j} \cdot \Delta \text { reserves }_{i}
$$

\footnotetext{
${ }^{25}$ Equation (7) can also contain dummies capturing time effects, quarter effect and differences across US states.
} 
where DECILE refers to the size of banks (by decile of the distribution on total assets), reserves denote changes in bank reserves and captures effects of monetary policy, while $\mathrm{C}$ the liquidity position of the banks.

The ECB has recently coordinated a huge research effort in order to obtain a general and comparable picture on the functioning of the credit channel in euro area countries. Ehrmann, Gambacorta, Martínez-Pagés, Sevestre and Worms (2001) study the first stage of the bank lending channel for the four largest euro area economies (France, Germany, Italy and Spain) using the Kashyap and Stein $(2000)$ specification by including inflation $\left(\Delta P_{t-j}\right)$ as an additional control variable:

$$
\begin{aligned}
\Delta L_{i t} & =\sum_{j=1}^{4} \alpha \Delta L_{j i t-j}+\sum_{j=1}^{4} \beta_{j} M_{i t-j}+\sum_{j=1}^{4} \beta_{j} Y_{t-j}+\sum_{j=1}^{4} \lambda_{j} \Delta P_{t-j} \\
& +C_{i t-1}\left(\phi+\sum_{j=1}^{4} \eta_{j} M_{i t-j}+\sum_{j=1}^{4} \kappa_{j} Y_{i t-j}+\sum_{j=1}^{4} \pi_{j} \Delta P_{t-j}\right)
\end{aligned}
$$

Where $C$ is bank characteristic such as liquidity, size and capitalisation. They demonstrate that only the liquidity position of the individual banks matters for loan growth in response to a monetary policy tightening/easing, whereas the size and capitalisation of banks appear to be of no relevance ${ }^{26}$. They also summarise the key findings of related research for smaller euro area economies. The liquidity position seems to be a major factor in transmitting the impact of monetary policy on credit supply, with the exception of Finland and Portugal. However, size also matters in Greece and the Netherlands and the bank capital channel is found to be operational in the Netherlands and Portugal.

Ehrmann et al. (2001) speculate regarding the unimportant role for capitalisation. Either the fact of using a simple and not risk-adjusted measure of capitalisation may be not an appropriate proxy or the high level of bank capitalisation does not leave too much room for the operation of the bank capital channel. Nevertheless, recent research casts some doubt on an overwhelming "liquidity channel". Altunbas, Fazylov and Molyneux (2002), using BankScope data and Pizarro-Barceló (2004), employing data obtained from Spanish sources support the existence of a bank capital channel in the euro area and in Spain, respectively. Pizarro-Barceló (2004) finds size to be an important factor for the credit channel. Gambacorta and Mistrulli (2003) redefines capitalisation as the excess capital and uncover that banks with excess capital react less to monetary policy shocks in Italy

The Second Stage - Firm's Balance Sheet The second stage of the credit channel - the firms balance sheet - has obtained less attention than the first

\footnotetext{
${ }^{26}$ They stress that the use of bank-level data obtained from BankScope is biased towards large banks as small banks are underrepresented. Therefore, they suggest the use of data collected at the national levels offering a broader coverage of the respective banking systems.
} 
stage as it is usually assumed that a considerable proportion of firms are bankdependent. Hence, once it is established that monetary policy is capable of impacting on credit supply, it is taken for granted that this effect will feed into the non-financial corporate sector.

Notwithstanding this observation, there are papers aimed at formally testing the validity of the second stage of the credit channel. For instance, Yalcin, Bougheas and Mizen (2004) redefine the "mix" variable as a measure of indebtedness of firms ${ }^{27}$ and investigate, for a panel of 16000 UK firms, how, after a change in monetary policy, the "mix" variable changes for firms ${ }^{28}$. In particular, they find that the debt ratio tend to be more sensitive to changes in monetary policy for small, risky, highly indebted, and young firms as opposed to large, secure, low-geared and well-established firms.

Also using large micro panels, Chatelain et al. (2001) find that manufacturing firms' investments are strongly dependent on sales and cash-flow. However, only Italian, and not German, French and Spanish firms respond differently to changes in sales and cash-flow in their investment demand as a function of their size.

\subsubsection{Studies Based on Credit Card Data}

Gross and Souleles (2000) propose differentiating between loan supply and demand using individual-level credit card data.. Data on credit limits and credit balances provides an excellent opportunity for analysing separately credit supply and credit demand. Although Gross and Souleles (2000) only look at how changes in credit limits affect debt accumulation and how sensitive credit balances to changes in account-specific interest rates are, it remains a promising avenue for future research to investigate the impact of monetary policy shocks on the supply of and demand for this type of consumer credit.

\subsubsection{Empirical Evidence on Trade Credit}

A number of empirical studies has recently shown the importance of trade credit in external financing, especially during times of monetary tightening. Trade credit amounts to up to a quarter of firms' liabilities in the US, Germany, France and Italy (Mateut, Bougheas and Mizen, 2002) and is considerably higher in the UK (Kohler, Britton and Yates, 2000). Mateut (2004) lists a number of papers underpinning the importance of trade credit.

Nilsen (2002) finds for a sample of US firms that small firms have more recourse on trade credit after a hardening of the monetary stance. Although

\footnotetext{
${ }^{27}$ They use three alternative definitions: a.) total short-term debt to total liabilities, b.) total debt to total liabilities and c.) short-term debt to total debt.

${ }^{28}$ The "mix" variable is regressed on monetary policy conditions (MPC), a dummy capturing tight and loose monetary policy for 1990-92 and 1993-1999 (MPP), respectively, and the separate and joint interaction of MPC and MPP with firm characteristics (small vs. large; risky vs. secure; young vs. old; highly vs. lowly indebted; high profitable vs. low profitable) and a number of control variables including total real assets (for size), credit rating, age, the solvency ratio and the gearing ratio.
} 
this is in line with the bank lending channel, it also implies that a decline in bank borrowing is compensated by a rise in trade credit. In addition, Nilsen (2002) also shows that large firms without bond rating increase trade credit. Hence, more firms may feel the pain of financial constraints than thought in the previous literature.Mateut, Boughas and Mizen (2003) report similar results for manufacturing firms in the UK.

\subsubsection{Summary}

A number of conclusions can be drawn on the basis of the above discussion, summarised in Table 2. The macro evidence seems to be fairly weak regarding the bank lending channel. However, loans to households may be more responsive to monetary policy shocks than corporate loans. Even so, it remains controversial the extent to which those changes matter for household consumption. The use of micro bank and firm level data suggests that bank lending activity may be affected by monetary policy. However, there is no consensus on which characteristics of banks (size, liquidity, capitalisation) matter most. The second stage of the bank lending channel appears to be more debated as some authors point out the existence of a broad lending channel instead of a bank lending channel. In addition, trade credit seems to be an important source of external financing for firms with no credit rating. 
Table 2. Summary of the Credit Channel in Developed Countries

\begin{tabular}{|c|c|c|c|c|c|c|}
\hline \multirow[t]{2}{*}{ Authors } & \multirow[t]{2}{*}{ Country } & \multicolumn{3}{|c|}{ Bank lendig channel(LC) } & \multirow{2}{*}{$\begin{array}{c}\text { Broad } \\
\text { LC }\end{array}$} & \multirow{2}{*}{$\begin{array}{l}\text { Trade } \\
\text { credit }\end{array}$} \\
\hline & & Overall & $1 \mathrm{st}$ & 2nd & & \\
\hline Bernanke-Gertler(1995) & US, spread & YES & & & & \\
\hline Kashyap et al. (1994) & US, spread & YES & & & & \\
\hline Miron et al (1994) & US, spread & $\mathrm{NO}$ & & & & \\
\hline Bernanke-Blinder (1992) & US, VAR & YES & & & & \\
\hline Morgan (1998) & US, VAR & NO & & & & \\
\hline Gertler-Bernanke (1993) & US, VAR & $\mathrm{NO} / \mathrm{YES}$ & & & & \\
\hline King (1986) & US & NO & & & & \\
\hline Romer-Romer (1990) & US & NO & & & & \\
\hline Ramey (1993) & US & NO & & & & \\
\hline Escriva-Haldale (1994) & Spain & $\mathrm{HH}$ & & & & \\
\hline Dale-Haldale (1995) & UK & $\mathrm{HH}$ & & & & \\
\hline Kakes (1998) & Netherlands & $\mathrm{HH} ?$ & & & & \\
\hline Kashyap et al. ('93,'96) & US & & & YES & & \\
\hline Oline-Rudebusch (1996) & US & & & NO & YES & \\
\hline Ludvigson (1998) & $\begin{array}{c}\text { US } \\
\text { automobile }\end{array}$ & & & small & & \\
\hline Kashyap-Stein ('95,'00) & US & & YES & & & \\
\hline Baum et al. (2004) & US & & YES & & & \\
\hline Favero et al. (1999) & Europe & & $\mathrm{NO}$ & & & \\
\hline Ehrmann et al. (2001) & Europe & & YES & & & \\
\hline Altunbas et al (2002) & Europe & & BK & & & \\
\hline Pizarro-Barceló (2004 ) & Spain & & BK & & & \\
\hline $\begin{array}{l}\text { Gambacorta and } \\
\text { Mistrulli (2003) }\end{array}$ & Italy & & $\mathrm{BK}$ & & & \\
\hline Yalcin et al. (2004) & UK & & & YES & YES & \\
\hline Chatelain et al. (2001) & Europe & & & YES & YES & \\
\hline Kohler et al (2000) & UK & & & & & YES \\
\hline Nilsen (2002) & US & & & & & YES \\
\hline Mateut et al (2002) & UK & & & & & YES \\
\hline Mateut (2005) & $\begin{array}{l}\text { US, UK } \\
\text { DE, AT }\end{array}$ & & & & & YES \\
\hline
\end{tabular}

Notes: BK denotes the existence of the bank capital channel. HH=loans to households,

? = questionable or weak evidence

\subsection{Empirical Evidence for the CEECs}

\subsubsection{Evidence from VAR-based Studies}

The body of empirical literature focusing on Central and Eastern Europe is quite a specialised literature, in the sense that most studies concentrate on the first stage of the bank lending channel and only a few make use of the VARbased approach. Hence, a number of possibilities still await for exploitation. 
Let us first consider the small amount of evidence that generated has from VAR models. Wróbel (2001) shows for Poland that a shock to short-term interest rates causes real credits to drop in the short run and to be stabilising at the lower level afterwards. Creel and Levasseur (2005) find that after the initial decrease, credit recovers for Poland. For the Czech Republic and Hungary, the results indicate a short-term rise, rather than a fall in the credit series after a monetary policy shock. Finally, Héricourt (2005) studies the impact of a credit shock on output and prices. The general outcome is that a credit shock temporarily increases both output and prices (for Poland, Slovakia and Slovenia). For the Czech Republic, output first falls and then recovers. For Estonia, the results for prices depend on whether GDP or industrial production is used. However, special care should be taken with these results because in some cases, the impulse-response functions (IRF) look unusual, i.e. exhibiting a cyclical fluctuation around zero, which is difficult to explain. The second cautionary note, applying to all three studies is that the vast majority of IRFs are not very significantly different from zero when taking account of the confidence intervals.

\subsubsection{Evidence from Micro Bank-Level Data}

Turning to the micro-data based evidence, this strand of the literature uses a variant of equation (9) employed in Ehrmann et al. (2001), which, in turn, is an improvement of Kashyap and Stein (2000). Note that equation (9) is usually estimated separately for different bank characteristics $(C)$. That is, a separate regression is run, for instance, for size, liquidity, capitalisation and ownership structure. Horváth, Krekó and Naszódi, (2005) extend this list with the average cost of funds. Note, however, that a number of authors also include include simultaneously all bank-specific characteristics (e.g. Havrylchyk and Jurzyk, 2005; Köhler, Hommel and Grote, 2005; Schmitz, 2004) or only two at the same time (Horváth, Krekó and Naszódi, 2005).

Overall, the empirical results strongly support the view that banks react differently to monetary policy changes depending on the above listed characteristics. However, the bank-level characteristics are not equally important. For instance, Juks (2004) finds that the supply of household and corporate loans turn out to be most affected for banks with a low level of liquidity, while bank size and capitalisation does not matter. Köhler, Hommel and Grote (2005) and Matousek and Sarantis (2006) come to a similar conclusion merging data on aggregate loans for the three Baltic countries although Matousek and Sarantis (2006) also find size as an important factor. Bank capitalisation may not matter for two reasons. First, capitalisation measured at the bank-level may not be an appropriate measure. Instead, the capitalisation of the whole bank holding should be considered. Second, as also noted by Ehrmann et al. (2001), bank capitalisation is high enough not to be affected by changes in monetary conditions. A final finding is that none of the three characteristics (size, liquidity and capitalisation) are correlated with corporate loan supply in a robust manner.

In a similar vein, Schmitz (2004) shows for a set of CEECs that size and the liquidity position seems to matter and that the reaction of foreign-owned banks 
is more pronounced to a change in domestic and foreign monetary conditions than their domestic counterparts. However, pooling all countries may mask considerable cross-country heterogeneities as country-specific studies suggest. An excellent example is Matousek and Sarantis (2006) who cover all CEE-5 plus the three Baltic countries to show substantial country differences. In addition to the heterogeneity prevailing across countries, sometimes the results are rather variable even for the very same country. Poland is a case in point. Havrylchyk and Jurzyk (2005) find that better liquidity position enables banks to insulate loans from monetary policy actions. Weak evidence is also found for the size of the banks. However, the estimated coefficient indicates that smaller banks are in a better position to shield themselves from monetary policy. Finally, bank capitalisation turns out to play no role in the lending behaviour of banks. This stands in strong contrast with Wróbel and Pawlowska (2002) who find that size and capitalisation explain in a standard manner (larger and more capitalised banks react less) bank lending behaviour in the face of a monetary policy move, while more liquid banks are more responsive to an increase in the policy rate than less liquid banks. This counterintuitive finding can be explained, according to the authors, by the overliquidity of the Polish banking sector. The most robust variable in the regressions run by Chmielewski (2005) and by Matousek and Sarantis (2006) is capitalisation, which indicates that better capitalised banks are shielded from the effects of monetary policy. Foreign involvement generally turns out to result in more responsiveness to monetary policy. The results for liquidity are in conformity with the findings in Wróbel and Pawlowska (2002). Finally, it deserves mentioning that the effect of bad loans may have opposite signs across different specifications, and, importantly, FX-denominated loans, especially those to households, are very much insensitive to monetary policy actions.

For the Czech Republic, while Matousek and Sarintis (2006) find that size, capitalisation and liquidity are important from 1994 to 2003, Pruteanu (2004) comes to the conlusion that better capitalised and more liquid banks appear to be less responsive to monetary policy from 1996 to 1998 but not from 1999 to 2001. In contrast, the result that larger banks and banks with more bad loans in their portfolio care less about monetary policy can lead back to the existence of a soft budget constraint mainly because of the unaccomplished privatisation of the banking sector. In addition, it seems that size is especially important for foreign banks for which the coefficient switches sign between the two sub-periods. From 1996 to 1998, larger foreign banks were more affected by monetary policy actions, while from 1999 to 2001, smaller foreign banks exhibited more responsiveness. Liquidity matters for foreign banks in the first sub-period, whilst it becomes important for Czech banks and foreign branches in the second subperiod.

For Hungary, Horváth, Krekó and Naszódi (2005) show that using more disaggregated loan series makes it is easier to pin down the bank lending channel and that all bank characteristics have a play to role although their results also reveal that some of the bank characteristics are not particularly robust. This is in contrast with Matousek and Sarintis (2006), who can identify size as the 
only variable explaning diverging bank lending activity as a result of monetary policy changes. Furthermore, the results reported in Horváth, Krekó and Naszódi (2005) indicate that FX denominated corporate loans are very much inresponsive to monetary policy actions.

Finally, according to Golodniuk (2005), Ukrainian banks react differently to changes only as a function of capitalisation but not as a function of size and liquidity. 
Table 3 Results of the Empirical Literature on CEE

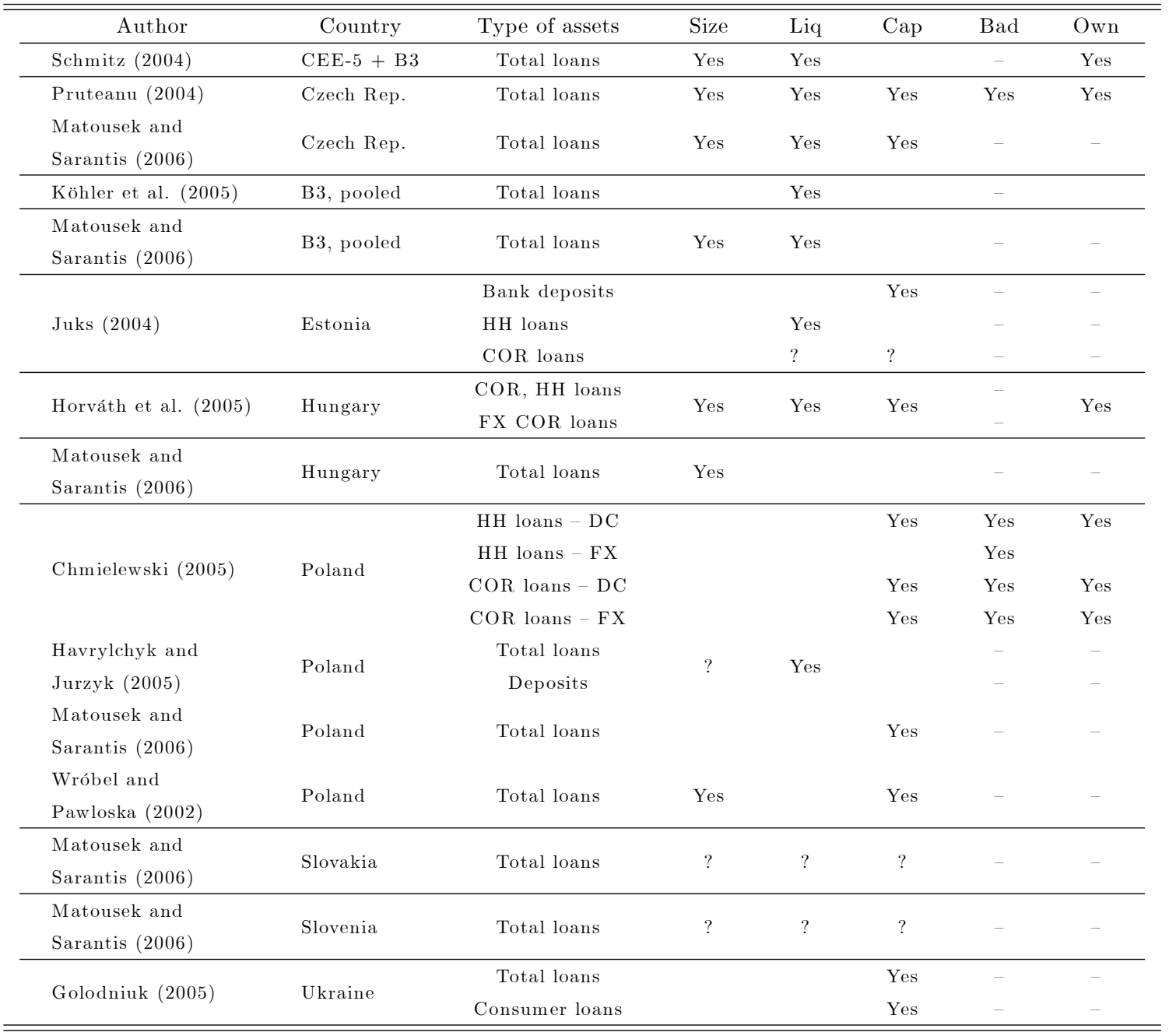

Note: ? indicates weak evidence in favor of the given variable. HH and COR stand

for households and the nonfinancial corporate sector. DC stands for loans denominated

in domestic currency, FX for those in foreign currency. CEE-5 stands for the Czech Republic,

Hungary, Poland, Slovakia and Slovenia; B3 stands for the three Baltic countries.

- indicates that the given variable is not included in the study

Liq, Cap, Bad and Own are liquidity, capitalization bad loans and ownership

\subsection{Some Criticism}

A number of critical remarks can be addressed vis-à-vis the literature aimed at studying the credit channel in Central and Eastern Europe. The literature is still very scarce and deals only with selected aspects of the credit channel. No attempt has so far been made to investigate systematically how interest rates 
affect credit aggregates and how changes in credit aggregates influence output and prices. This is in particular true for micro- based panel studies, which have yet to analyse the second stage of the bank lending channel. As we know, even though bank lending behaviour is influenced by monetary policy steps, for the bank lending channel to be operational, it needs to be verified whether firms are solely relying on bank loans.

Chmielewski (2005) provides a good example in looking at loan series split into domestic and foreign currency denomination and into corporate and household loans. Perhaps a little more disaggregation looking at diverse segments of the corporate and household market (short-term, long-term, consumer, housing and automobile credit) would provide a better understanding of how, if at all, the credit channel works in Central and Eastern Europe. A remaining future challenge is to obtain estimates from bank- and firm-level datasets regarding the adjustment taking place in output and prices in the aftermath of a change in monetary policy.

But perhaps the most important shortcoming of the literature, relating to the credit channel in general, is to assume that credit markets are in equilibrium and that the credit series used for estimation purposes reflects this equilibrium. However, disequilibrium at the credit market may have important implications for monetary policy. If there is excess demand for credit, banks tend to ration, and for this reason, may amplify (attenuate) the effect of a monetary policy tightening (loosening). In contrast, if the supply of credit exceeds the demand for credit, perhaps because banks hold too much liquidity, banks will not pass through changes in the policy rate on their retail rates in the event of a monetary policy tightening ${ }^{29}$, because this would reduce the demand for credit, already insufficient to clear the market. Nonetheless, an interest rate cut would be very quickly incorporated into loan rates (Hurlin and Kierzenkowski, 2002, 2003). Hurlin and Kierzekowski (2003) identify excess supply of credit until mid-1999 and a regime of excess demand for credit in Poland and argue that the existence of these two regimes may explain why Polish monetary policy became much more efficient after 1999.

\section{Exchange Rate Channel}

Beside interest rates and asset prices, both nominal and real exchange rates play a prominent role in the monetary transmission mechanism. Monetary policy is able to bring about changes in the level of the exchange rate and thus to provoke changes in (a) prices, (b) trade volumes and (c) investment. The first stage of the transmission mechanism is how short-term interest rates impact on exchange rates. The second stage is then the pass-through from exchange rates to import and domestic prices, followed by an adjustment in real variables such as imports, exports and investment.

\footnotetext{
${ }^{29}$ This is the connection how the state of the credit market influences the interest rate pass-through.
} 


\subsection{Monetary Policy Actions and the Exchange Rate}

Central to all open economy macro models is a variant of the real interest rate parity (RIP) condition, which links the expected change in the real exchange rate to a real interest differential ${ }^{30}$. Although the extant evidence on this relationship is rather mixed this, as Baxter (1994) initially noted, it is more a reflection of the application of inappropriate econometric methods (in particular mixing I(1) and $\mathrm{I}(0)$ variables) than any inherent deficiency in the relationship itself (see also Hoffman and MacDonald, 2005). MacDonald and Nagayasu (1999) have demonstrated strong support for the RIP condition in a panel setting and Chinn and Meredith (2005) have demonstrated support for long horizon interest rate maturities.

In addition to changes in the short-term interest rate, monetary authorities may also influence short-run exchange rate movements by directly intervening on the foreign exchange markets. Although it is widely acknowledged that unsterilised interventions affect the exchange rate by altering relative money supplies, the empirical evidence is fairly mixed regarding the effectiveness of sterilized interventions, which may work through the portfolio, the signaling and the microstructure (or co-ordination) channels. In their literature survey, Sarno and Taylor (2001) conclude, however, that what emerges from studies focusing on the 1990s is that interventions tend to impact on the exchange rates, "especially if the intervention is publicly announced and concerted and provided it is consistent with the underlying stance of monetary and fiscal policy".

\subsection{Exchange Rate and Prices}

Generally, nominal exchange rate movements provoked by monetary policy action have the potential ${ }^{31}$ to be translated into domestic inflation on the grounds of a modification of imported final goods prices, and because an alteration in the price of imported intermediate goods puts, via the price of domestically manufactured tradable and non-tradable goods, downward or upward pressure on domestic inflation $(\mathrm{FX}=>$ import prices $=>$ consumer prices and $\mathrm{FX}=>$ import prices $=>$ producer prices $=>$ consumer prices $)$.

How the exchange rate affects domestic prices via imported prices in the end depends crucially on the pricing behaviour of importing firms. If prices are set in the importer's prices (producer currency pricing; $\mathrm{PCP}$ ), any change in the exchange rate will be automatically transmitted onto prices of the destination country. This implies complete exchange rate pass-through, which is sometimes also referred to as Grassman's Law, and the validity of the law of one price since

\footnotetext{
${ }^{30}$ This is central to the Mundell-Fleming-Dornbusch model and also to the New Open Economy Macroeconomics (see Obstfeld and Rogoff, 1996); a risk adjusted variant of real interest rate parity is also central to the portfolio balance class of model - see, for example, Mussa (1986).

${ }^{31}$ The word potential has to be underlined here, as a great deal of factors aside from monetary policy has the ability to cause the exchange rate to change. As a result, the pass-through of exchange rate to prices is only partly due to monetary policy action.
} 
the real exchange rate remains stable ${ }^{32}$.

Alternatively, if the price of imported goods is fixed in the local currency (local or consumer currency pricing; LCP), exchange rate movements are not reflected in domestic prices and the pass-through is zero. As a consequence, the real exchange rate may drift away from the level given by the law of one price and is correlated with the nominal exchange rate $^{33}$. Importing firms practicing LCP will alter their mark-up in response to changes in the exchange rate, while those engaging in PCP usually adjust their output and labour in response to changes in local prices.

\subsubsection{Differing Pass-Through for Imported, Producer and Consumer Prices}

A typical finding of the empirical literature for imported goods prices is that the pass-through lies between 0 and 1 , which disqualifies both LCP and PCP (Campa and Goldberg, 2002) ${ }^{34}$. According to the consensus of the literature reported in Goldberg and Knetter (1997), the pass-through from exchange rate to import prices is of $60 \%$ for the US. More recent studies find even lower long-run pass-through to import prices (Campa and Goldberg (2002): 29.2\% and Mihailov (2005): 24.4\%). Pass-through estimates are typically higher for other developed countries. For instance, Campa and Goldberg (2002) report a pass-through of around $40 \%$ and $80 \%$ for Germany and Japan, respectively, while Mihailov (2005) finds complete pass-through to import prices for these two economies.

The incomplete pass-through to import prices may be due to third degree price discrimination eventually preventing a complete pass-through even for homogenous imported goods. For price discrimination to apply, it is necessary that i.) firms are able to separate different markets from each other, ii.) firms are capable of preventing the resale of the products and iii.) they have market power (Goldberg and Knetter, 1997). Additional factors explaining market segmentation are: (a) transportation costs, (b) custom duties, (c) non-tariff barriers, (d) differences in characteristics of even relatively homogenous products, (e) home or brand loyalty, (f) presence of multinationals, and (g) intra-firm trade (Darvas, 2001).

However, even if we assume perfect pass-through for imported goods, the large body of literature dealing with the exchange rate pass-through usually pins down the following hierarchy across prices: the pass-through is highest for imported goods, is lower for producer goods and is lowest for consumer prices. Although this is not at first sight surprising, when account is taken for purely

\footnotetext{
${ }^{32}$ Another implication is that a change in the relative price of imported and domestic goods will shift consumption from one type of goods to the other type of goods (expenditure switching).

${ }^{33}$ This is indeed a well documented fact for industrialised countries (see MacDonald, 2005).

${ }^{34}$ Choudhry et al. (2005) find that the theoretical model that best fits the data is the one that incorporate sticky prices and wages, distribution costs and a combination of LCP and PCP.
} 
domestically produced goods and services (without any imported intermediate input), we may think of this issue in two ways:

1. One strand of the literature emphasises the role of distribution costs for final imported goods. As imported goods reach consumers through wholesaling and retailing networks (including transportation, marketing and advertisement), their prices have a substantial local input, which serves as a buffer to attenuate exchange rate changes. Burstein, Eichenbaum and Rebelo (2002, 2004), for example, show that large devaluations of the home currency are not reflected in inflation of corresponding size because of the distribution sector, and because consumers switch from imported goods to local brands of lower quality and, hence, of lower price (flight from quality). Analogously, large appreciations may not necessarily yield lower inflation if there is a flight to quality.

2. Other researchers emphasise the role of intermediate imported goods by assuming that imported goods are intermediate goods to which PCP applies (that is, there is full pass-through). The price of the final goods, which is a combination of imported intermediate goods and local goods, is set in the local currency (Engel, 2002) ${ }^{35}$. The pass-through would be higher than zero but sluggish in the event that prices in local currency are adjusted periodically (due to sticky prices) when exchange rate movements could be also incorporated.

\subsubsection{Slow-Down of the Pass-Through to Prices Over Time?}

Another important finding in the literature is that the exchange rate passthrough is higher for developing countries and that it declines over time both for industrialised and for developing countries ${ }^{36}$. Two explanations are advanced for this observation in the literature. The first one relates to the role of macroeconomic variables, especially inflation. The second option considers the shift in imports from goods with higher pass-through towards goods with lower passthrough elasticities.

The Role of the Macroeconomic Environment Taylor (2000) conjectured that the slow-down in the pass-through (and the difference between developing and developed countries) is due to changes in the macroeconomic environment, in particular in the level and variability of inflation rates. This proposition has been extensively tested in a two-stage approach similar to that used for the investigation of the determinants of the interest rate pass-through. First, country-specific exchange rate pass-through coefficients are estimated. Second, the estimated coefficients are regressed on a number of candidate explanatory variables. Devereux and Yetman (2003) and Choudhry and Hakura (2001) show for a sample of 122 and 71 countries, respectively that high inflation is conducive to perfect pass-through and is often associated with complete pass-through ${ }^{37}$.

\footnotetext{
${ }^{35}$ In this sense, there is expenditure switching for the producer and not for the consumer.

${ }^{36}$ Campa and Goldberg (2002) argue that the decline in the exchange rate passthrough can be observed only for half of the OECD countries.

${ }^{37}$ This is in accord with the literature on PPP. If PPP holds for the traded goods sector, i.e. the real exchange rate is stable at a given horizon, the pass-through could
} 
Ca'Zorzi, Hahn and Sanchez (2005) come to similar conclusions using a smaller set of developing and developed countries. This is because menu costs are outweighed by costs related to high inflation. Consequently, firms adjust prices in every period eliminating price stickiness and thus improving pass-through. Devereux and Yetman (2003) also demonstrate that the level of inflation does not explain pass-through once the sample is split into low and high-inflation countries. While the above mentioned studies are relying on a two-stage approach in which country-specific pass-through coefficients are estimated first and then regressed on potential explanatory variables, Bailliu and Fujii (2004) use a panel setting in which changes in inflation rates are controlled for by means of dummy variables. In contrast to the earlier literature, it turns out that the pass-through declined for import, producer and consumer prices for a set of 11 OECD countries during the 1990s. Gagnon and Ihrig (2001), and especially Soto and Selaive (2003), claim that inflation variability is more important than the level of the inflation. In addition, Soto and Selaive (2003) also find openness and country size to be an important factors in determining the pass-through. The higher the openness and the smaller a country ${ }^{38}$, they argue, the higher the pass-through.

The Composition of Trade and Imports Even though Campa and Goldberg (2002) confirm the importance of inflation, and also that of exchange rate volatility $^{39}$, they emphasise that the macroeconomic factors are dominated in the long run by what they call the 'composition effect'. As pass-through is nearly complete for energy and raw materials and is considerably lower than unity for food and manufactured products, a shift in the composition of imports from raw materials towards manufactured goods, the argument goes, induces a decline in the exchange rate pass-through for imported goods. The econometric tests support this idea for a sample of OECD countries. This is also the kind of reasoning that could be applied to explain why the pass-through is higher for developing countries (importing more high pass-through goods) than in developed countries (importing more low-pass-through goods)

Evidence Based on Individual Imported Goods Frankel, Parsley and Wei (2005) study the pass-through to prices of individual goods ${ }^{40}$ for a large set of countries. In general, it turns out that pass-through is not complete for import prices at the dock. Also, the pass-through to import prices in the US is found to be considerably lower than for other developed economies. Given

be viewed as highly efficient. But empirical observations confirm that PPP seems to hold for very high-inflation countries, but this is apparently not the case of lowinflation economies. In addition to this, Peel, Sarno and Taylor (2002) put forward that the pass-through is non-linear, that is nominal exchange rates impact on prices only if they are large enough.

${ }^{38}$ They measure openness in three alternative ways: 1.) imports to GDP, 2.) import duties as a share of imports and 3.) tariff rates on intermediate and capital goods.

${ }^{39}$ Note that Soto and Selaive (2003) cannot find evidence, for a larger sample, for exchange rate volatility as a driving force behind exchange rate pass-through.

${ }^{40}$ Marlboro cigarettes, Coca-cola, Cognac, Gilbey's gin, Time magazine, Kodak colour film, Cointreau liqueur and Martini\&Rossi Vermouth. 
the high disaggregation of the data, the composition effect cannot be at the root of this phenomenon, which mitigates the Campa and Goldberg argument. However, it is also unearthed that the pass-through to import prices increased over time, while it decreased for retail and the CPI level for developing countries (but not for developed ones). The cross sectional dimension of the date reveals that the most important factors influencing the size of the pass-through are a.) distance (transport costs), b.) GDP per capita, c.) the level of inflation, and to a lesser extent d.) the size of the economy.

The Role of Expectations Finally, at the heart of the pass-through process are expectations of the extent of the pass-through and the transitory or permanent nature of the change in the exchange rate. While changes perceived as transitory will not affect prices, changes which are regarded as permanent will impact on prices. The role of the exchange rate regime is not, in general, dealt with in this literature, although the pass-through is thought to be higher for countries where the exchange rate serves as a nominal anchor to inflationary expectations. In this case any change in the exchange rate will be rapidly incorporated into expectations and thus into prices (both tradable and non-tradable). In contrast, if the exchange rate is not used as an intermediary target, expectations are not that strongly associated with the exchange rate, resulting in a lower pass-through. A floating exchange rate regime will little influence non-tradable prices.

\subsection{The Impact of the Exchange Rate on Trade and In- vestment}

As regards trade flows, an appreciation (depreciation) of the exchange rate is thought to penalise (promote) exports and increase imports leading to deteriorating (improving) trade balance. However, this holds true only if the MarshallLerner condition is verified and the sum of the price elasticities of export and import demand is higher than unity. The functioning of the Marshall-Lerner condition is also based on full pass-through to import prices (in local currency) and zero pass-through to export prices (in foreign currency). Hence, the failure of complete pass-through implies that the Marshall-Lerner condition need not apply.

Burstein, Neves and Rebelo (2004) document the fact that the import content of investment is significantly higher than the import content of consumption. As a result, the pass-through to investment prices is potentially higher than that to the price of consumer goods. However, pass-through is also incomplete because of the non-tradable component of investment. Contrary to consumer goods, the bulk of the non-tradable component is due to construction services while the share of distribution services is negligible.

Campa and Goldberg (1995) postulate that the impact of the exchange rate on sectoral investment depends on the export share and the import content of production of the sector. More specifically, exchange rate depreciation (ap- 
preciation) expands (decreases) investment if the export share is high. A high import content of sectoral production works in the opposite direction. Furthermore, high mark-up sectors do not tend to respond to exchange rate movements in investment demand, whereas low mark-up sectors respond stronger to changes in the exchange rate.

We can draw a connection here between the exchange rate channel and the credit channel. The effect of the credit channel (see below) on the economic activity of firms constrained by external finance is exacerbated if these firms are in low mark-up sectors. The second relation linking the exchange rate channel and the credit channel is how the foreign currency denominated assets and liabilities in firms' balance sheet and thus their net wealth is influenced by exchange rate movements. If changes in the exchange rate impact on significantly on firms' balance sheet, it will influence their capacity to borrow externally (broad lending channel). A collapse in investment due to an exchange rate-induced fall in firms' net wealth may outweigh competitiveness gains provided the Marshall-Lerner condition is verified (Carranza, Galdón-Sánchez and Gómez-Biscarri, 2004).

It is worth mentioning that not only the level but also the variability of the exchange rate is an important factor for trade and investment. Although the the relationship between exchange rate volatility and aggregate or bilateral export flows seems to be ambiguous for developed countries, differentiating between sectors suggests a negative relationship between exchange rate volatility and export flows. Hence, the higher the exchange rate volatility, the more trade is penalised, and consequently investment is affected. Nonetheless, the impact of volatility differs both in magnitude and direction across sectors. For developing countries, the literature unanimously supports the hypothesis that exchange rate volatility has a negative effect on exports flows (for an overview, see, for example, McKenzie, 1999).

\subsection{Estimation Issues for Exchange Rate Pass-Through}

A common practice in the literature is to estimate the exchange rate passthrough either relying on VAR models or using a single equation approach incorporating differenced variables or employing single equations in which the deviation from the long-run equilibrium exchange rate is modelled. We shall touch upon each approach successively.

The VAR methodology typically makes use of a recursive VAR derived on the basis of the distribution chain model devised by McCarthy (1999) (as in equations 10 to 15 below) which starts with oil price inflation $\left(\Delta p_{t}^{\text {oil }}\right)$, goes through output gap $\left(\tilde{y}_{t}\right)$, exchange rate movements $\left(\Delta e_{t}\right)$, import price inflation $\left(\Delta p_{t}^{\text {import }}\right)$, producer price inflation $\left(\Delta p_{t}^{P P I}\right)$ and ends up with consumer price inflation $\left(\triangle p_{t}^{C P I}\right)$ :

$$
\begin{gathered}
\Delta p_{t}^{o i l}=E_{t-1}\left(\Delta p_{t}^{o i l}\right)+\epsilon_{t}^{s} \\
\tilde{y}_{t}=E_{t-1}\left(\tilde{y}_{t}\right)+\beta_{11} \epsilon_{t}^{s}+\epsilon_{t}^{d} \\
\Delta e_{t}=E_{t-1}\left(\Delta e_{t}\right)+\beta_{21} \epsilon_{t}^{s}+\beta_{22} \epsilon_{t}^{d}+\epsilon_{t}^{e}
\end{gathered}
$$




$$
\begin{gathered}
\Delta p_{t}^{\text {import }}=E_{t-1}\left(\Delta p_{t}^{\text {import }}\right)+\beta_{31} \epsilon_{t}^{s}+\beta_{32} \epsilon_{t}^{d}+\beta_{33} \epsilon_{t}^{e}+\epsilon_{t}^{\text {import }} \\
\Delta p_{t}^{P P I}=E_{t-1}\left(\Delta p_{t}^{P P I}\right)+\beta_{41} \epsilon_{t}^{s}+\beta_{42} \epsilon_{t}^{d}+\beta_{43} \epsilon_{t}^{e}+\beta_{44} \epsilon_{t}^{\text {import }}+\epsilon_{t}^{P P I} \\
\Delta p_{t}^{C P I}=E_{t-1}\left(\Delta p_{t}^{C P I}\right)+\beta_{51} \epsilon_{t}^{s}+\beta_{52} \epsilon_{t}^{d}+\beta_{53} \epsilon_{t}^{e}+\beta_{54} \epsilon_{t}^{i m p o r t}+\beta_{55} \epsilon_{t}^{P P I}+\epsilon_{t}^{C P I}
\end{gathered}
$$

The conditional expectations in equations (10) to (15) can then be approximated by linear projections of the lagged variables included in the system.

For transition economies, oil price inflation is usually replaced by changes in the price of commodities and the import price inflation is not considered because of data problems (Gueorguiev, 2003, Billmeier and Bonato, 2002, Bitâns, 2003). These authors then assume implicitly complete pass-through to import prices. In contrast, Ca'Zorzi, Hahn and Sanchez (2005) consider import and consumer prices and include short-term interest rates in addition. Gueorguiev (2003) extends the model with changes in total labour costs, following commodity price inflation in the second equation of the system. Korhonen and Wachtel (2005) use a simpler VAR model, which contains oil price inflation, foreign CPI inflation, changes in the exchange rate and domestic CPI inflation in this order.

A second strand of the literature relies on a variant of the specification suggested by Campa and Goldberg (2002):

$$
p_{t}=\alpha+\beta e_{t}+\chi p_{t}^{*}+\delta Z_{t}+\epsilon_{t}
$$

where $p_{t}^{*}$ stands for foreign prices and $Z_{t}$ is a vector of control variables. Because variables in equation (16) are usually $\mathrm{I}(1)$, most authors estimate an ARDL representation:

$$
\Delta p_{t}=\alpha+\sum_{j=1}^{k} \beta_{j} \Delta p_{t-j}+\sum_{j=0}^{l} \varphi_{j} \Delta e_{t-j}+\sum_{i=1}^{n} \sum_{j=0}^{m} \delta_{i j} z_{i t-j}+\epsilon_{t}
$$

with $\mathrm{k}, \mathrm{l}$ and $\mathrm{m}$ being the maximum number of lags, $\mathrm{n}$ the number of control variables. In this setting, short-term pass-through is given by $\varphi_{o}$ while the longrun pass-through is obtained as $\sum_{j=0}^{l} \varphi_{j} /\left(1-\sum_{j=1}^{k} \beta_{j}\right)$. Note that some authors use a simpified version of (17). Campa and Golderg (2002) and Mihailov (2005) do not include lagged values of the dependent variable ${ }^{41}$. Bailliu and Fujii (2004) take foreign unit labour costs and output gap on board. Choudhry and Hakura (2001) include only foreign prices but no other control variables while Rodzko (2004) ignores both foreign prices and other control variables. Devereux and Yetman (2003) use an even more rudimentary specification with only one lagged exchange rate changes and a simultanous foreign price terms on the right-hand side $\left(\Delta p_{t}=\varphi \Delta e_{t-1}+\delta \Delta p_{t}^{*}+\epsilon_{t}\right)$. The only papers with a focus on transition economies, which include control variables (output gap and real GDP) other than foreign prices are Mihaljek and Klau (2001) and Dabusinskas (2003).

\footnotetext{
${ }^{41}$ In their version of the equation, the log-run elasticity is given simply as: $\sum_{j=0}^{l} \varphi_{j}$
} 
Evidently, exchange rate pass-through is intimately related to equilibrium exchange rates and to real misalignments. Both the VAR approach and the above-noted single-equation approach largely ignore this issue, which may mean there is an omitted variable bias which could have serious implications for the estimated pass-through. For industrialised countries, it means that large nonequilibrium deviations from PPP should be accounted for when analysing exchange rate pass-through (Frankel, Parsley and Wei, 2005). The issue is possibly even more important for transition countries because their equilibrium exchange rates exhibit large changes, in particular a strong tend appreciation during the phase of economic transformation ${ }^{42}$. Hence, the trending movement of the equilibrium exchange rate and the deviation of the real exchange rate from this trend should be clearly considered for the study of the pass-through. Darvas (2001) stands out from the rest of the literature in that he models equilibrium exchange rate and the degree of exchange rate pass-trough jointly. In particular, he first estimates the equilibrium exchange rate using the single-equation Behavioural Equilibrium Exchange Rate (BEER) approach. Next, prices and the nominal exchange rate are estimated using the following system:

$$
\begin{gathered}
\Delta p_{t}=\alpha+\beta \Delta e_{t}+\chi \Delta p_{t}^{*}+\delta\left(q_{t-1}-q_{t-1}^{E Q}\right)+\epsilon_{t} \\
\Delta e_{t}=\gamma+\eta\left(q_{t-1}-q_{t-1}^{E Q}\right)+\epsilon_{t}
\end{gathered}
$$

where $\left(q_{t-1}-q_{t-1}^{E Q}\right)$ measures the misalignment of the real exchange rate. In this setting, $\beta$ represents the instantaneous long-run pass-through. Moreover, Darvas (2001) allows for time-varying parameters in his specification given that the pass-through may (and does according to his results) change over time.

\subsubsection{Exchange Rate Pass-Through in Transition Economies}

Short-term Interest Rates and the Exchange Rate An increasing number of papers have used the VAR methodology to study the impact of monetary policy innovations on the most important macroeconomic variables. These papers, surveyed in more detail below, also address the impact of shocks in shortterm interest rates on the nominal exchange rate and produce mixed results since positive interest rate shocks can lead to an appreciation or depreciation of the exchange rate. The latter phenomenon is usually referred to as the exchange rate puzzle., which under special circumstances can be attributed to the unsuccessful defence of a given exchange rate level.

Relying on a different methodological framework, Rezessy (2004) shows that for Hungary changes in the key policy rate led to systematic changes in the exchange rate and he reports the absence of an exchange rate puzzle since a rise in the policy rate causes the exchange rate to appreciate.

Central Bank Interventions in the Foreign Exchange Market It is now becoming increasingly accepted that foreign exchange interventions may

\footnotetext{
${ }^{42}$ For an overview of this issue, see e.g. Égert, Halpern and MacDonald (2004).
} 
be more effective in emerging market economies as compared to well-established industrialized countries for the following reasons (Canales-Kriljenko, 2003):

a.) central bank interventions are not always fully sterilized;

b.) the size of interventions is large relative to market turnover in narrow forex markets;

c.) the market organization and the regulatory framework may be more conducive to interventions;

d.) moral suasion may play a bigger role;

e.) because of the larger informational advantage of the central banks vis-àvis market participants.

For the case of transition economies only a few papers study the effectiveness of FX interventions using daily data ${ }^{43}$. It is meant under effectiveness that central bank interventions in the FX market are capable of slowing down trends (exchange rate smoothing) or even reversing the exchange rate trend (leaning against the wind). Disyatat and Galati (2005) could not find any significant impact of daily FX interventions on the exchange rate of the Czech koruna using daily data from 2001 to 2002. Instead, interventions tend to increase FX volatility.

However, Holub (2004) applies an event study approach to monthly data and shows that interventions tend to be effective and on a number of occasions, consistent with inflation targeting. Also relying on the event study approach - but applied to daily data, and completed with GARCH estimations - Égert and Komarek (2005) provide some additional supportive evidence in favour of the fact that FX interventions slowed down the appreciation of the koruna from 1999 to 2002, especially when FX interventions were supported by interest rate policy in a consistent manner. ${ }^{44}$ Égert and Lang (2005) also reveal that although the Croatian National Bank was not particularly successful in influencing the exchange rate during the late 1990s, official FX interventions were fairly effective in turning the trend on the FX markets from 2000 to 2004.

Exchange Rate Pass-Through to Inflation Table 4 summarises the average short-term and long-term exchange rate pass-through estimates ${ }^{45}$. Notwithstanding the substantial shortcomings on the estimation side ${ }^{46}$, the average ex-

\footnotetext{
${ }^{43}$ BIS(2005) provides a collection of foreign exchange intervention practices in the Czech Republic, Hungary and Poland and for a large number of emerging market economies.

${ }^{44}$ The conflicting results obtained by Disyatat and Galati (2005) on the one hand, and Holub (2004) and Égert and Komarek (2005) on the other hand might be due to the omission of macroeconomic news from the event study approaches. However, weak instruments may also cause the failure of Disyatat and Galati (2005) to find that FX interventions are not successful. Their estimation results obtained from 2001 to 2002 may be considerably weakened by the fact that only three observations for FX intervention are available for 2001.

${ }^{45}$ The individual studies dealing with the exchange rate pass-through in transition economies and their specific pass-through estimates are summarised in the annex.

${ }^{46}$ Another cautionary note is needed as some authors use sample periods going well before the economic transition started in 1990. Campa and Goldberg (2002), Choudhri and Hakura (2001) and Soto and Selaive (2003) employ data going back to the 1970s,
} 
change rate pass-through, reported in the row "average" of Table 4 reveals the incomplete nature of the pass-through from the exchange rate to prices, not only in the short-run but also at a longer horizon. At the same time, Table 4 also shows the term structure of the pass-through, which turns out to be highest for import prices with an average pass-through of $62 \%$. A $1 \%$ change in the exchange rate results in an average $0.52 \%$ change in producer prices. Finally, and as expected, the overall impact is the lowest on the consumer price index. However, Table 2 and a closer look at the individual studies render this picture much more varied for the following reasons:

1. cross-country heterogeneity of the pass-through especially for the CPI

2. the pass-through is different for different sub-groups of the CPI, PPI and import prices

3. exchange rate pass-through has declined lately for almost all countries

4. the pass-through seems strongest against the anchor or benchmark currency

We shall tackle these issues one by one in what follows.

A first obvious observation is the large heterogeneity across countries regarding pass-through to the CPI. CPI inflation is less affected by the exchange rate in the Czech Republic and is the highest in Slovenia (53\%) and Bulgaria (68\%). The pass-through is also below the sample average for Romania (for the dollar).

In addition, two tentative observations can be made. Pass-through to the CPI tends to be higher for countries at a lower stage of development (Korhonen and Wachtel, 2005). Also, we can observe larger pass-through for countries with accommodative monetary policy at some stage (Slovenia and Romania). If a country operates an explicit or implicit crawling peg exchange rate regime, the pre-announced devaluation of the currency provides a nominal anchor for expectations. As changes in the exchange rate may signal changes in prices, changes in the exchange rate will generate corresponding changes in prices not only for tradables but also for non-tradables, via the expectation channel. This would imply a high and quite homogenous pass-through for the whole CPI. The move towards more exchange rate flexibility, coupled with an inflation targeting framework may break the link between the exchange rate and prices by disconnecting primarily non-tradables from the exchange rate (Coricelli, Jacbec and Masten, 2003; Darvas, 2001 and Kara et al, 2005).

However, studies focusing on one country sometimes strongly disagree regarding the size of the pass-through. One prominent example is Estonia: while Dabušinskas (2003) finds a zero pass-through to the $\mathrm{CPI}^{47}$, Bitans (2004) reports an average pass-through of $53 \%$.

Second, Dobrynskaya and Levando (2005) identify for the Russian case higher pass-through to food and good prices (around 50\% and 30\% in the long-run), and virtually no pass-through to services. The finding for food is broadly in line

while the sample period starts in 1988 for Hungary in Ca'Zorzi, Hahn and Sanchez (2005).

${ }^{47}$ Given that the nominal exchange rate is fixed vis-à-vis the euro in the currency board arrangement, the pass-through measures how changes in the nominal effective exchange rate are translated into inflation. 
with Dabusinskas (2003) for Estonia. However, somewhat oddly, pass-through is not present for goods in the Estonian CPI.

Mihaljek and Klau (2001) claims that using a measure of CPI cleaned from non-market prices, such as administered and regulated prices increases the longrun pass-through. Comparing their estimates for the Czech Republic, Hungary and Poland with the rest of the sample verifies this assumption. Along these lines, it turns out that the pass-through is biased downwards by roughly $10 \%$ for Latvia when the price measure includes non-market prices (Bitans, 2004).

The pass-through appears to be larger against the anchor or reference currency. This point is clearly demonstrated for Romania (Gueorguiev, 2003 and Korhonen and Wachtel, 2005), where pass-through is about twice as large against the dollar than vis-à-vis the euro. Inversely, changes in the dollar exchange rate matter little for prices in the Czech Republic and Hungary, for instance.

The exchange rate pass-through is found to be higher higher for the PPI as compared to the CPI for all countries except Croatia and Russia. Even for the Czech Republic, with the lowest pass-through to the CPI, roughly $40 \%$ of exchange rate changes are passed on to producer prices. For the remaining countries, pass-through to PPI is usually above $50 \%$. It is also more convenient to take the market-based component of the PPI. While no pass-through could be found on the basis of the overall PPI for Estonia, PPI for manufacturing (net of energy, mining prices for instance) reflects a large amount of changes in the effective exchange rate. Overall, producer prices of manufactured goods, in particular, machinery and equipment, are more receptive with regard to changes in the exchange rate than other items.

The pass-through to the price of imported goods is nearly complete in Estonia, Hungary and Poland and it is complete in Slovakia, while it below the pass-through to the PPI for Latvia and Lithuania and Slovenia. Although a similar degree of heterogeneity can be found for sub-groups of imported goods, pass-through is highest in machinery equipments, followed by other manufactured and chemical goods.

A criticism of the above work lies in its failure to address possible asymmetries in the pass-through. The pass-through could be different depending on whether the exchange rate depreciations, appreciates or not, whether changes in the exchange rate exceed a certain threshold (are large enough) or how much the exchange rate deviates from its equilibrium level. The exploration of these issues awaits future research.

\subsubsection{Exchange Rate Pass-Through and the Labour Market}

It is interesting to note the role labour market adjustments may play in the exchange rate pass-through. Jakab and Kovács (2003) perform model (NIGEM)based simulations in order to analyse the relative roles of factors affecting exchange rate pass-through. What emerges from their simulations is that expectations and goods markets explain most of the pass-through in the short- and medium-run. In contrast, adjustments in labour markets driven by changes in 
the exchange rate start having some effect on domestic prices only with a delay of three years and more. This is because the labour market first reacts in terms of quantities (employment/unemployment), and only over time in terms of prices (wages). In the event of a simulated nominal appreciation, it turns out that the negative output gap caused by a real appreciation of the domestic currency first increases unemployment. Rising unemployment subsequently puts downward pressure on wages, which is finally felt in domestic prices. The total amount by which changes in the exchange rate feeds into prices via the labour market depends on how much the response of wages to an increase in unemployment is, i.e. how flexible the labour market is.

\subsubsection{Determinants of Exchange Rate Pass-Through}

Although several authors have linked the size of the pass-through to the level of inflation (Darvas, 2001) and to the type of the exchange rate regime (Coricelli et al., 2003), the only study which performed a cross-sectional analysis is Bitans (2004), who shows for a sample of transition economies that the size of the exchange rate pass-through is strongly linked to

1.) the rate of inflation,

2.) exchange rate persistence,

3.) import structure (measured as the share of machinery and electronic equipment in total imports of goods, and to some extent, to

4.) openness.

Overall, although the pass-through may have increased up to mid- or late1990s (Campa and Goldberg, 2002), it seems to be falling since then as convincingly evidenced by Bitans (2004) who argues this finding is closely related to the decline in inflation rates.

An interesting finding is that the pass-through for manufactured goods tends to be higher than for raw materials both for import and for producer prices (Rodzko, 2004). This could invalidate the composition effect put forth by Campa and Goldberg (2002). 
Table 4 Summary of the Exchange Rate Pass-Through

\begin{tabular}{|c|c|c|c|c|c|c|}
\hline & \multicolumn{2}{|c|}{ Import prices } & \multicolumn{2}{|c|}{ PPI } & \multicolumn{2}{|c|}{ CPI } \\
\hline & short-run & long-run & short-run & long-run & short-run & long-run \\
\hline \multicolumn{7}{|c|}{ Average of the sample } \\
\hline Average & 0.44 & 0.70 & 0.16 & 0.52 & 0.31 & 0.33 \\
\hline \multirow{2}{*}{\multicolumn{7}{|c|}{$\begin{array}{c}\text { Country-specific averages } \\
C E E-5\end{array}$}} \\
\hline & & & & & & \\
\hline Czech Rep. & 0.34 & 0.65 & - & 0.41 & 0.10 & 0.23 \\
\hline Hungary & 0.58 & 0.87 & - & 0.57 & 0.38 & 0.30 \\
\hline Poland & 0.57 & 0.84 & - & 0.60 & - & 0.31 \\
\hline Slovakia & 0.41 & 1.01 & - & 0.73 & - & 0.35 \\
\hline Slovenia & 0.26 & 0.40 & - & 0.78 & 0.20 & 0.53 \\
\hline \multicolumn{7}{|c|}{ Baltic Three } \\
\hline Estonia & 0.59 & 0.83 & - & 0.47 & 0.00 & 0.35 \\
\hline Latvia & 0.43 & 0.45 & - & 0.66 & - & 0.39 \\
\hline Lithuania & 0.22 & 0.32 & - & 0.55 & 0.07 & 0.32 \\
\hline \multicolumn{7}{|c|}{ SEE } \\
\hline Bulgaria & - & - & - & 0.94 & - & 0.68 \\
\hline Croatia & - & - & - & 0.17 & - & 0.22 \\
\hline Romania & & & & & & \\
\hline (EFF/EUR) & - & - & 0.22 & 0.48 & 0.06 & 0.21 \\
\hline (USD) & - & - & 0.23 & 0.53 & 0.28 & 0.42 \\
\hline \multicolumn{7}{|c|}{ CIS } \\
\hline Russia & - & - & 0.11 & 0.23 & 0.42 & 0.40 \\
\hline Ukraine & - & - & - & - & - & 0.44 \\
\hline
\end{tabular}

Note: The averages are based on nonnegative pass-through estimates. Negative pass-through estimates were set to zero. The average of country specific averages does not equal the figure given in the row "Average," as the sample specific average is obtained as the average of all available pass-through estimates. EFF, EUR and USD indicate the pass-through from the effective exchange rate and from the euro and dollar exchange rates, respectively.

\subsubsection{Exchange Rate Volatility and Trade Flows}

The influence of exchange rate volatility on exports has been studied in Égert and Morales-Zumaquero (2005) for a number of Central and Eastern European countries. On the basis of standard export equations, augmented with FDI, the panel estimations indicate that a rise in forex volatility, measured either directly or via changes in the exchange rate regime hinders exports, and that this negative impact is transmitted with some delay rather than being instantaneous. It turns our that sectors, such as chemicals and different types of manufacturing adding up to $80 \%$ of total exports suffer most from increased exchange rate volatility. Nevertheless, country-specific time series estimations reveal a great deal of heterogeneity across countries. For instance, there is little or weak evidence in favour of a negative relation between forex volatility and exports Slovenia, Russia and Romania, while for Croatia, the Czech Republic, Hungary 
and Poland, the estimation results provide reasonably robust evidence on the detrimental effect of forex volatility on exports.

\section{Asset Price Channel}

Monetary policy is also capable of influencing asset prices, such as equity and housing. From a monetarist viewpoint, in the event that an expansionary monetary policy results in increased money supply, the actual level of liquidity held by the public will exceed their desired level. This, in turn, leads market participants to seek to decrease liquidity at their disposal by buying equity, bonds and housing which results in a rise in the respective prices. An increase in bond prices is automatically translated into a decrease in the interest rate, already under pressure through the interest rate channel. Falling interest rates will then increase the attractiveness of equities fuelling equity purchases and causing equity prices to rise further. However, asset price reactions to monetary policy action can be asymmetric in nature. For instance, Ehrmann and Fratzscher (2004) show for the US that the reaction of stock prices to a change in the interest rate is amplified if the change in the interest rate is unexpected $^{48}$, if the change goes in the other direction than in the previous period (decrease following an increase or vica versa) and in the presence of high stock market volatility.

\subsection{The Non-Financial Corporate Sector}

Higher equity prices eventually exert an influence on investment spending by altering the relationship between the cost of capital and the stock market valuation of that capital. This mechanism is described by Tobin's $q$ theory, where $q$ is defined as the market value of firms over the replacement cost of capital. Similarly, an increase in equity prices also affects households' spending via the wealth effect.. The basic idea in the $q$ story is that as $q$ rises above unity firms find their market value is high relative to the replacement cost of capital and therefore new investments are cheaper relative to the market value of firms. As a consequence, issuing fewer new shares at high prices enables firms to buy more new equipment at lower prices and this results in higher investment spending.

The $q$ theory is also applicable to the housing market. For example, a higherthan-unity $q$ implies market value above replacement cost, and this promotes construction production. Conversely, if $q$ is below 1 , firms would not seek to buy new equipment because it is more advantageous to acquire other firms with market value less than their replacement cost of capital. Likewise, it is more favourable to buy old houses instead of constructing new ones. As a result, investment, household spending and construction activity decrease.

\footnotetext{
${ }^{48}$ The strong form of the efficient market hypothesis holds that asset prices incorporate all available information (even that publicly not available). Hence, only the unexpected component of the change can have an influence on asset prices.
} 
The empirical literature on Tobin's $q$ focuses on whether investment is correlated more with stock markets than with fundamentals (such as sales, cash-flow, profits or net present value of profits). While some authors find that investment follows closely fundamentals (Blanchard, Rhee and Summers, 1993), and that it is arguably difficult to relate Tobin's q to the evolution of investment because of problems encountered when measuring the replacement cost of capital, there appears to be a broad consensus in the literature that stock prices and market valuation matter, to some extent, for investment decisions (Alexandre, 2002).

If market valuation plays a role in investment decisions, large fluctuations in asset prices unrelated to fundamentals, which lead to over- or undervaluation of asset prices, can cause over- or under-investment ${ }^{49}$ This raises the question of whether monetary policy should respond to asset price bubbles. The question is all the more relevant since asset price booms and busts are observed to occur on a regular basis (Filardo, 2004). According to Bernanke and Gertler (2000), monetary policy should react to asset prices only if they influence expected future inflation. It is also argued that reacting to asset prices may induce increased inflation volatility. However, Alexandre (2002) demonstrates that reacting to non-fundamental shocks to asset prices leads not only to more stability in inflation and asset prices, but also to more stable investment and thus, ultimately, to more stable output. Filardo (2004) argues that monetary policy should step in only in the event that an asset price bubble has macroeconomic implications ("macroeconomic" asset price bubble). Although it may prove tricky to identify and to react to such bubbles, Cecchetti et al. (2000) consider uncertainty not to exceed that prevailing for other parts of the monetary transmission mechanism.

In addition, bubbles in different asset markets may be related to one another, which makes it even more difficult to deal with them properly. It is a stylised fact that the collapse of stock market bubbles is typically followed by a surge in property prices, largely as a consequence of a monetary loosening to ease the effects the burst on the equity market. Hence, "bubbles beget bubbles via a policy channel" (Filardi, 2004).

\subsection{Households}

The wealth effect channel of equity and property prices is closely related to Modigliani's lifecycle theory (Modigliani (1971) in which households' consumption spending is believed to be driven by disposable lifetime wealth. Because equity and property is part of this wealth, a rise (fall) in equity and housing prices triggered by monetary policy action results in increasing (diminishing) lifetime wealth and thus leads to an increase (decrease) in consumption spending.

An alternative view to the wealth effect is the so-called liquidity effect. In line with Mishkin (2001), spending on durable goods and housing is by a large

\footnotetext{
${ }^{49}$ The fundamental component of asset prices reflects fundamentals such as the net present value of profits or dividends and hence does not cause fundamentals. In contrast, the non-fundamental part of asset prices leads to distortions in investment decisions, and, thus it causes fundamentals (Filardo, 2004).
} 
extent influenced by consumers' perception regarding the likelihood of running into financial difficulties. The higher the ratio of liquid financial assets to debt, the lower the probability of financial distress will be. Thus, an increase in equity prices decreases the danger of future problems related to debt and therefore encourages households to consume more goods and housing.

\subsection{Spillover from or to Other Channels in the Transmis- sion Mechanism}

The asset price channel interferes with other channels of the monetary transmission mechanism, and hence may amplify the overall transmission, mainly through the broad lending channel. A rise (fall) in the price of an asset (such as a stock, bond and housing) triggered by monetary policy action strengthens (weakens) the balance sheet of firms and households. This, in turn, increases (lowers) their capacity to borrow from external sources via the external financing premium.

If the credit channel is operational, then an increase (decrease) in interest rates can lead to a drop (rise) in the stock price of firms which are subject to financial constraint because such firms are unable to supply their preferred amount of goods and services, so their expected future profits fall. This effect, in turn, has a feedback on the credit channel since a change in stock prices changes the external financing premium of the firm and of firms and households (plus wealth effect) that hold the shares of the firm.

A change in the monetary policy stance can also lead to firms' share prices becoming more heterogeneous. The market valuation of those firms will change more, which produce interest-sensitive goods or services as a change in interest rates modifies the demand for their goods and services (interest rate channel, Ehrmann and Fratzscher, 2004). In a second stage, such firms are more exposed to the credit channel.

\section{Systematic versus Shocking Effects of Mone- tary Policy}

The literature reviewed thus far relates to the systematic effects of monetary policy actions on inflation and the real economy. However, VAR studies provide a (black-box) framework in which the impact of monetary policy shocks on prices, output and macroeconomic variables can be quantified. This section summarises the main issues of this literature, namely the prize puzzle and then presents the empirical findings for the CEECs.

\subsection{Price Puzzle I.}

A huge amount of effort has been devoted to uncovering the impact of an unexpected monetary policy shock on output and inflation. This literature has produced the so-called "price puzzle" according to which a monetary policy 
contraction causes a rise in the inflation rate rather than a drop. While some authors qualified only the response of prices non-sensual and went on interpreting the reaction of the other variables to the shock, the vast majority of researchers have argued that the price puzzle invalidates all the other responses as well. In this spirit, several suggestions have been proposed to deal with this problem $^{50}$.

A first group of papers, including that of Sims (1992), claimed that the forward looking component of the monetary policy shock might have been misidentified, and the inclusion of commodity prices in the system makes the puzzle disappear. The underlying idea of this line of thinking is that policy makers in central banks also look at variables, disregarded by academic studies, which help in forecasting inflation. Yet VAR models extended in this manner usually include only up to 8 or 10 variables, which represents only a small proportion of the information set available to policymakers. The combination of factor analysis with VAR models, giving rise to factor-augmented VARs (FAVAR), provides a remedy to this problem. In such a setting, a small number of factors (principal components) summarises the information extracted from a large number (perhaps over 100) of time series (Bernanke, Boivin and Eliasz, 2005).

However, Giordani (2004) and Hanson (2004) argue that variables good at predicting inflation (such as accurate inflation forecasts) are not helpful in solving the price puzzle. Giordani (2004) emphasises the need to use the output gap as a remedy for the puzzle. Indeed, commodity prices may help to mitigate the puzzle only because they are correlated with the US business cycle. Hanson (2004) shows that the price puzzle is due to the fact that the estimated VAR models cover periods during which there is a change in the monetary policy rule. Once the period is carefully hand-picked to remove overlaps between different monetary policy rules, the price puzzle disappears.

Another strand of the literature, initiated by Barth and Ramey (2000) take the position that the price puzzle is not generated by methodological problems. Instead, prices tend to rise in the wake of a monetary policy tightening because an increase in interest rates gives rise to higher production costs reflected in higher inflation rate. They find that the so-called cost-channel was more important during the 1960s and 1970s and then declined during the 1980s and the 1990 s in the US economy ${ }^{51}$. For small open economies, the price puzzle is likely to arise if the nominal exchange rate is not included in the VAR (Kim and Roubini, 2000).

\footnotetext{
${ }^{50} \mathrm{~A}$ more fundamental criticism of the VAR literature formulated by Bernanke, Gertler and Watson(1997) and McCallum (1999) is that VAR models capture only the unanticipated changes in monetary policy rather that the systematic relationships, which connects monetary policy instruments and the economy. Accounting for longrun relations is all the more import as the unexpected component of monetary policy represents only a small fraction of changes in monetary policy (McCallum, 1999).

${ }^{51}$ As they put, unexpected monetary policy shocks can be best viewed as a combination of cost (supply) shocks and demand shocks.
} 


\subsection{Price Puzzle II.}

Another type of price puzzle seems to emerge for emerging market economies. In these countries, a monetary restriction causes a rise in inflation if public debt is high. According to this view, a monetary policy tightening reflected in higher real interest rates increases the probability that the government will default as a consequence of higher interest payments. Hence, the risk premium rises, and this pushes foreign capital to leave the country, which, in turn, causes the exchange rate to depreciate. If exchange rate pass-through to domestic prices is high enough, such a depreciation leads to rising inflation (Blanchard, 2004 and Favero and Giavazzi, 2004) $)^{5253}$.

\subsection{Exchange Rate Puzzle}

Mojon and Peersman (2001) detect an exchange rate depreciation in the aftermath of a monetary policy innovation for Italy and Spain, which had trouble in defending their exchange rate in 1993. This so-called exchange rate puzzle can be traced back to the fact that monetary policy reacted with an increase in the short-term interest rates, mostly in vein. This also helps in explaining the price puzzle because nominal exchange rate depreciation feeds into domestic inflation (exchange rate pass-through). Nonetheless, if monetary policy shocks are in fact a response to changes in the exchange rate, then the issue at hand is the misidentification of monetary policy shocks leading to a basic dismissal of the results.

\subsection{Empirical Findings for Industrialised Countries}

Recently, considerable effort has been undertaken to scrutinise heterogeneities in the monetary transmission mechanism to a monetary policy innovation between the US economy and the euro area are during the 1990s. This research, summarised in Angeloni et al. (2003), indicates that the price puzzle may be absent in the euro area, while a small increase in prices can be observed in the US immediately after monetary tightening. This is presumably due to the fact that the cost channel tends to be small in the US during the 1990s but is even less important for the euro area (Rabanal, 2003). In the longer run, prices tend to fall, gradually but permanently in the euro area as well as in the US. A second finding is that output reacts in a similar way in both economic entities. It first drops but then recovers gradually (humped shaped reaction). Nevertheless, the real difference between the euro area and the US is that output responses are determined more by household consumption rather than by investment in the

\footnotetext{
${ }^{52}$ Recall that Burstein et al. (2002, 2004) show that the inflationary effect of a large devaluation will be limited because of the distribution related component of goods sold to the consumers and because of the switch from imported goods to domestic substitutes.

${ }^{53}$ The price puzzle was developed in the context of Brazil. It also applies to the case of other large emerging markets such as Turkey (Aktas et al., 2005).
} 
US, while the opposite appears to be the case in the euro area. This heterogeneity, also termed the "output composition puzzle" results, Angeloni et al. (2003) argue, from differences in households' reaction. At the same time, firms respond in a more homogenous manner to monetary policy shocks in the Us and the euro area.

VAR studies unveil the asymmetric effects of a monetary policy shock both over the business cycle and across sectors. It appears that euro area countries are more responsive to monetary policy shocks in recessions than in good times (Peersman and Smets, 2001, 2002). Monetary policy shocks also turn out to impact sectors in an asymmetric way. Peersman and Smets (2002) point out that sectors producing durable goods, with more capital intensity and being more open tend to react more to monetary policy shocks. This is indeed evidence for the interest rate channel. Dedola and Lippi (2000) partly confirm this finding.

But they also uncover that manufacturing sectors including a larger number of small or more leveraged firms (lower smaller borrowing capacity) react stronger to monetary policy shocks than other sectors.

\subsection{Empirical Findings for CEECs}

Heterogeneity in results is an accompanying phenomenon of the ever growing number of VAR studies with a focus on the CEECs. According to Table 5, which reports the main conclusions of the individual papers, different and apparently inconsistent results can be found for a given country. In this sense, the price puzzle, a permanent decline or a temporary fall in the inflation rate after a monetary policy contraction can be obtained for the same country. Also, output may increase, decline permanently or exhibit a humped shape following a monetary policy shock. However, it turns out that studies covering the entire transition period ${ }^{54}$ starting in the early 1990s, and relying on recursive VAR models (EFN, 2004; Creel and Levasseur, 2005; Héricourt, 2005) tend to obtain price puzzle. In contrast, papers allowing for changes in the parameter estimates either through splitting the whole sample into sub-samples (Arnostova and Hurník, 2004; Vonnák, 2005) or by relying on genuine time-varying coefficient estimates (Darvas, 2005) or by employing a more sophisticated and hence more precise identification scheme of monetary policy innovation (Vonnák, 2005; Jarocińki, 2005). The price puzzle in the Czech Republic may be due to the emergence of the exchange rate puzzle during the 1997 period (Arnostova and Hurník, 2004). Jarociński (2005) compares the mean of the impulse-reponse functions of $4 \mathrm{CEE}$ economies (Czech Republic, Hungary, Poland, Slovenia) to that of five euro area countries (Finland, France, Germany, Italy and Spain) and finds that the reaction of prices and output to monetary policy shocks is stronger in the CEECs than in the euro area.

In sum, as put forth by Elbourne and de Haan (2003) for industrialised

\footnotetext{
${ }^{54}$ Quite surprising is the fact that EFN (2004) estimates a VAR for Hungary for a period starting in 1985. Obviously, it is difficult to obtain meaningful results when a period covers the end of central planning, the early and later stages of the transition process.
} 
countries, the main sources of cross-study heterogeneity in results are a.) the different time period, b.) the use of different schemes to identify monetary policy shocks and c.) the use of a different set of variables ${ }^{55}$.

\footnotetext{
${ }^{55}$ Héricourt (2005) also argues that it does matter whether one employs industrial production or GDP figures for output.
} 
Table 5 Summary of VAR Results

\begin{tabular}{|c|c|}
\hline Author & Results \\
\hline Arnostova and & $\mathrm{CZ}$, full period: foreign exchange and price puzzle, output: U-shaped \\
\hline Hurník (2004) & 1998, price and output: U-shaped, no foreign exchange puzzle \\
\hline Bitans et al. (2003) & LV, prices: slow decrease and then slow recovery \\
\hline Creel and & Inflation: price puzzle for all countries \\
\hline Levasseur (2005) & Output increases for 1999 to 2004 , no reaction for $\mathrm{HU}$ \\
\hline Darvas (2005) & $\begin{array}{l}\text { Price puzzle in } \mathrm{CZ}(1998,2004), \mathrm{HU}(1994,1998) \text {, drop in prices in } \mathrm{PL} \\
\text { Output: drops most in } \mathrm{PL} \text {, least in } \mathrm{HU} \text {, but recovers more quickly in } \mathrm{PL} \\
\text { than in } \mathrm{HU} \text {; Response profiles change over time }\end{array}$ \\
\hline $\operatorname{EFN}(2004)$ & $\begin{array}{l}\text { Mostly not significant (EE, SI, LT) } \\
\text { Inflation: CZ price puzzle, HU, LV U-shaped, SK permanent decrease (Q), } \\
\text { U-shaped (M), PL no significant change }(\mathrm{Q}, \mathrm{M}) \\
\text { Output: CZ, HU U-shaped; PL strong drop then recovery }(\mathrm{M}), \\
\text { SK permanent increase }\end{array}$ \\
\hline $\begin{array}{l}\text { Elbourne and } \\
\text { de Haan (2006) }\end{array}$ & $\begin{array}{l}\text { CEE-10; inflation: largest and quickest drop in SK and RO; PL, } \\
\text { CZ protracted, others small;HU: price puzzle } \\
\text { Output: large and quick drop; CZ mostly quick; SK and EE slow }\end{array}$ \\
\hline Ganev et al. (2002) & $\begin{array}{l}\text { Inflation: } \mathrm{SI}, \mathrm{CZ} \text { permanent rise, } \mathrm{LV}, \mathrm{SK} \text { temporary fall, } \mathrm{HU} \text { permanent fall } \\
\text { Output: decrease is fastest in } \mathrm{HU} \text {, more permanent in } \mathrm{CZ} \text {, decreases and } \\
\text { adjustment in SK and SI, increases in the remaining countries; } \\
\mathrm{BG}, \mathrm{RO} \text { : large fluctuations }\end{array}$ \\
\hline Héricourt (2005) & $\begin{array}{l}\text { Inflation: } \mathrm{CZ} \text {, price and fforeign exchange puzzle; HU, SI price puzzle } \\
\text { Output: CZ, GDP and IIP different } \\
\text { EE, PL, SK: no significant change }\end{array}$ \\
\hline Jarociński (2005) & CEE-4: decline in output and prices \\
\hline Kuijs (2001 & $\begin{array}{l}\text { M2 shock: SK, increase in inflation (unit labor cost increase), } \\
\text { little impact on output. }\end{array}$ \\
\hline Maliszewski (1999) & $\begin{array}{l}\text { Inflation: PL declines and recovers partially } \\
\text { Output: PL declines and recovers partially (more strongly than inflation) }\end{array}$ \\
\hline Maliszewski (2002) & $\begin{array}{l}\text { Inflation: } \mathrm{CZ}, \mathrm{PL} \text { slow decline and stabilization at lower level } \\
\text { Output: CZ, PL hump-shaped, but not full recovery }\end{array}$ \\
\hline Vonnák (2005) & $\begin{array}{l}\text { HU: } 1992 \text { to } 2003 \text { price puzzle } \\
\text { HU: } 1995 \text { to } 2003 \text { quick decline in output, slow decline in prices, } \\
\text { currency appreciation }\end{array}$ \\
\hline Wróbel (2001) & $\begin{array}{l}\text { Prices: PL increase followed by decrease and slight recovery, but still negative } \\
\text { Output: PL increase followed by decrease and full recovery } \\
\text { Credit: PL large decrease followed by slow recovery }\end{array}$ \\
\hline
\end{tabular}

Note:CZ, EE, HU, LV, LT, PL, RO, SK, SI denote the Czech Republic, Estonia, Hungary, Latvia,

Lithuania, Poland, Romania, Slovakia and Slovenia. The CEE-10 includes these countries and

Bulgaria. The CEE-4 covers CZ, HU, PL and SI. Q and M refer to quarterly and monthly frequencies. 


\section{Concluding Remarks}

We now look at determinants of the different channels, set out in earlier parts of the paper, which may give us some clues on the past and possibly future development of the different channels. Starting with the very first step of the transmission mechanism, we have seen that the pass-through improved substantially from the beginning of the transition until today both in terms of the speed of adjustment towards long-term pass through and the size of the long-run passthrough. This is mostly because of the development of the financial and banking sectors in the countries.

Speculating for the future from the macroeconomic side, money market volatility is bound to fall to euro area levels after euro adoption and financial depth is likely to be rising in the years to come. At the same time, inflation rates are closing the gap to the inflation rate of the euro area and long-run GDP growth may also slow down as real convergence progresses. The first two factors work towards an increase in the pass-through while the next two variables could decrease it. As to the structure of the banking sector, countries such as Poland, Slovenia and Latvia have less foreign investors in the banking sector, partly due to fewer advances in banking sector reforms. Poland and Slovenia are the countries with the highest burden of non-performing loans and Slovenia has the lowest capital adequacy ratio, but still comparable to the euro area. All this is admittedly detrimental to the pass-through. So, by making efforts on the front of banking reforms, these countries would be able to enhance interest rate pass-through. However, market concentration has been recently on the rise in most of the countries. Very high concentration rates can be observed in Estonia and Lithuania, while concentration is lowest in Hungary and Poland. Generally, market concentrations higher than in the euro area and yet on the rise makes us believe that interest rate pass-through may slow down and become less complete in the future in these countries.

We summarise the issue of exchange rate pass-through. Although trade and import exposure rose sharply in all countries except for Slovenia, the exchange rate pass-through has decreased over time and is expected to be stabilising at a lower level. The main reason for this is the steady fall in inflation rates to very low levels, perhaps with the exception of Romania and Russia, and the abandonment of accommodative monetary policies. The composition effect, measured as an increase in the share of manufactured goods in total imports, is fairly substantial in all countries, with the exception of Slovenia. However, its role is not clear-cut given that the pass-through for these groups of goods is found to be higher on occasions than for more homogeneous goods. Even so, and because of an expected decline in inflation and exchange rate volatilities, which are relatively high at present, the exchange rate channel will loose, if it has not lost already, its prominent role in the monetary transmission mechanism. However, changes in the exchange rate may have a strong impact on the balance sheet of firms and households, if there is a currency mismatch between revenues

and expenditures. Currency mismatch may be an issue because of the recent surge in foreign currency denominated household loans and, to a lesser extent, 
loans to the corporate sector. After euro adoption, the effect of the pass.through will be coming directly from trade with countries outside the euro area, and indirectly via the direct impact of the major currencies' fluctuations against the euro (euro/yen, euro/GBP and euro/USD) on the main euro area trading partners such as Germany, France and Italy.

The asset price channel is still of limited importance and is probably going to remain a low profile transmission channel. Stock and bond markets matter little to investment and consumption decisions through the wealth and income effects, given that these markets are dominated massively by foreign investors rather than by domestic ones. As a consequence, price movements on these markets have limited impact on the domestic economy via these two effects. Even though the effect of monetary policy via the property market appears to be not very important for the time being, this channel may grow more powerful in the future with the dynamic development of borrowing related to housing.

The limited role of the capital market does not only manifest for the asset prices channel but has also important implications for the credit channel. Obviously, new funds raised on both stock and bond markets is virtually close to zero in the CEECs, as only a very limited number of companies get listed on the stock market and as bond markets are used for financing public debt. This is unlikely to change in the near future. As a consequence, one may think that the financing of the non-financial corporate sector transmits through the banking sector.However, it is doubtful that the credit channel has a significant role to play in the CEECs either. First, the high concentration of the banking sectors, the heavy involvement of foreigners, the high degree of liquidity and more than sufficient levels of bank capitalisation render banks less responsive to domestic monetary policy impulses. Second, notwithstanding the absence of well functioning capital markets, firms may escape from domestic credit markets either by borrowing in foreign currency or by relying on trade credit and other kinds of inter-firm loans relating to transnational network created by FDI.

The good news for the effectiveness of monetary policy is, however, that firms capable of escaping domestic monetary policy conditions are strongly influenced by monetary policy in the euro area either because foreign currency loans are denominated in euros, or because their parent institutions are themselves subjected to the credit channel in the euro area. However, the good news would be really good if monetary conditions for the average of the euro area would be appropriate and not too loose for the transition economies as well.

When looking at the recipient sectors and the distribution of small and large firms across sectors, it appears that the manufacturing sector is less subject to the credit channel as compared to the rest of the economy, in particular to the services sectors. First, FDI flowed more than proportionately into the manufacturing sector. Second, small firms are mostly concentrated in non-tradables. To put the argument the other way around, the credit channel is likely to be operational for the market-based non-tradable sector and may have a strong impact on this part of the economy. Even though services account for about $70 \%$ of GDP in most countries, the country-specific impact is heterogeneous depending on how large the contribution of small firms to GDP is and how large public 
involvement in non-tradable sectors is (see Annex C).

In addition, households have no choice but to rely on bank borrowing. We will inevitably see the emergence and a subsequent strengthening of the credit channel for households with a build-up of the stock of household loans. However, monetary policy will affect this segment of the economy only partially and relatively slowly given that the interest rate pass-through is the lowest and most sluggish for consumer loans. As we have argued, the interest rate pass-through may slow down in the course of the coming years. This may indeed further cushion the impact of monetary policy through the credit channel.

Finally, while the credit channel is likely to be at work, or to gain importance in the non-tradable sector and for households, the interest rate channel may have a larger impact on the manufacturing sector. The final impact of monetary policy on output and prices of the manufacturing sector depends crucially on how parts of manufacturing react to changes in the interest rate. Although the share of manufacturing is pretty stable around $20 \%$ for all countries under study, its composition differs to a large extent. For instance, food production occupies an important role in Poland, Bulgaria, Croatia and Romania, while the Czech Republic, Hungary and Slovakia excel in producing electrical, optical and transport equipment. To the extent that these sectors differ in terms of markup (high or low mark-up sectors), they may have different reactions in different channels, as we set out this issue earlier. Hence, a heterogeneous response of these sectors to monetary policy innovations may generate substantial crosscountry heterogeneity to monetary policy impulses.

\section{References}

Adams, R.M. and D.F. Amel (2005): The Effects of the Local Banking Market Structure on the Bank Lending Channel of Monetary Policy, The Federal Reserve Board, Finance an Economics Discussion Series No. 16.

Akerlof, G. (1970): The Market of 'Lemons': Qualitative Uncertainty and the Market Mechanism, Quarterly Journal of Economics, 84(3), 488-500.

Aktaş, Z., Kaya, N. and Ü. Özlale (2005): The Price Puzzle in Emerging Markets: Evidence from the Turkish Ecomy Using Model Based Risk Premium Derived from Domestic Fundamentals, Central Bank of the Republic of Turkey Working Paper No. 2.

Alexandre, F. (2002): Monetary Policy, Investment and Non-Fundamental Shocks, Birkbeck College, mimeo.

Altunbas, Y., Fazylov, O. and P. Molyneux (2002): Evidence on the Bank Lending Channel in Europe, Journal of Banking and Finance, 26(11), 2093-2110.

Angeloni, I., Kashyap, A.K., Mojon, B. and D. Terlizzese (2003): The Output Composition Puzzle: A Difference in the Monetary Transmission Mechanism in the Euro Area and U.S., Journal of Money, Credit and Banking, 35(6), 1265-1306.

Arnoštova. K. and J. Hurník (2004): The Monetary Transmission Mechanism in the Czech Republic: Evidence from the VAR Analysis, Paper presented 
at the $3^{\text {rd }}$ Macroeconomic Policy Research Workshop, 29-30 October, National Bank of Hungary

Árvai, Zs. (1998): The Interest Rate Transmission Mechanism between Market and Commercial Bank Rates, National Bank of Hungary Working Paper No. 10.

Ashkraft, A.B. (2001): New Evidence on the Lending Channel, Federal Reserve Bank of New York Staff Reports No. 136.

Bailliu, J. and E. Fujii (2004): Exchange Rate Pass-Through and the Inflation Environment in Industrialized Countries: An Empirical Investigation, Bank of Canada Working Paper No. 21.

Bank for International Settlements (2005): Foreign Exchange Market Intervention in Emerging Markets: Motives, Techniques and Implications, BIS Papers No. 24.

Barth, M. J. and V.A. Ramey (2000): The Cost Channel of Monetary Policy, NBER Working Paper No. 7675.

Baum, C.F., Caglayan, M. and N. Ozkan (2004): Re-examining the Transmission of Monetary Policy: What More Do a Million Observations Have to Say, mimeo.

Baxter, M. (1994), "Real Exchange Rates and Real Interest Rate Differentials: Have we Missed the Business Cycle Relationship?" Journal of Monetary Economics, 33, 5-37

Bernanke, B. S. and A. Blinder (1988): Credit, Money and Aggregated Demand, American Economic Review Proceeding Papers, 78(2), 435-439.

Bernanke, B.S. and A. Blinder (1992): The Federal Funds Rate and the Channel of Monetary Transmission, American Economic Review, 82(4), 901921.

Bernanke, B.S. and M.L. Gertler (2000): Monetary Policy and Asset Price Volatility, NBER Working Paper No. 7559.

Bernanke, B.S., Boivin, J. and P. Eliasz (2005): Measuring the Effects of Monetary Policy: A Factor-Augmented Vector Autoregressive (FAVAR) Approach, Quarterly Journal of Economics, 120(1), 387-422.

Bernanke, B.S., Gertler, M. and M. Watson (1997): Systematic Monetary Policy and the Effects of Oil Price Shocks, C.V. Starr Center für Applied Economics, New York University, Working Paper No. 25.

Bernanke, Ben S. and Gertler, Mark (1995): Inside the black box: The credit channel of monetary policy, Journal of Economic Perspectives, Vol. 9. No. 4., pp. 27-48.

Bernstein, S. and R. Fuentes (2003): Is there lending rate stickiness in the Chilean banking industry? Central Bank of Chile Working Papers No. 218.

Billmeier, A. and L. Bonato (2002): Exchange Rate Pass-Through and Monetary Policy in Croatia, IMF Working Paper No. 109.

Bitâns, M. (2004): Pass-Through of Exchange Rates to Domestic Prices in East European Countries and the Role of Economic Environment, Bank of Latvia Working Paper No. 4.

Bitâns, M., Stikuts, D. and I. Tillers (2003): Transmission of Monetary Shocks in Latvia, Bank of Latvia Working Paper No. 1. 
Blanchard, O. (2004): Fiscal Dominance and Inflation Targeting: Lessons from Brazil, NBER Working Paper No. 10389.

Blanchard, O.J., Rhee, C. and L. Summers (1993): The Stock Market, Profit and Investment, Quarterly Journal of Economics, 108, 115-136.

Buch, C. (2001): Money Demand in Hungary and Poland, Applied Economics, 33(8), 989-999.

Budina, N., Maliszewski, W., deMenil, G. and G. Turlea (2002): Money, Inflation and Output in Romania, 1992-2000, DELTA Working Paper No. 15.

Burstein, A., Eichenbaum, M. and S. Rebelo (2002): Why Are Rates of Inflation So Low After Large Devaluation? NBER Working Paper No. 8748.

Burstein, A., Eichenbaum, M. and S. Rebelo (2004): Large Devaluations and the Real Exchange Rate, CEPR Discussion Paper No. 4810.

Burstein, A., Neves, J.C. and S. Rebelo (2004): Investment Prices and Exchange Rates: Some Basic Facts, NBER Working Paper No. 10238.

Ca'Zorzi, M., Hahn, E. and M. Sanchez (2005): Exchange Rate Pass-Through in Emerging Markets, ECB, mimeo.

Campa, J.M. and L.S. Goldberg (1995): Investment, Pass-Through and Exchange Rates: A Cross-Country Comparison, NBER Working Paper No. 5139.

Campa, J.M. and L.S. Goldberg (2002): Exchange Rate Pass-Through into Import Prices: A Macro or Micro Phenomenon? NBER Working Paper No. 8934.

Canales-Kriljenko, J. I. (2003): Foreign Exchange Intervention in Developing and Transition Economies: Results of a Survey, IMF Working Paper No. 95.

Carranza, L., Galdón-Sánchez, J.E. and J. Gómez-Biscarri (2004): Exchange Rate and Inflation Dynamics in Dollarized Economies, University of Navarra, mimeo.

Cecchetti, S.G., Genberg, H., Lipsky, J. and S. Waghwani (2000): Asset Prices and Central Bank Policy, Geneva Reports on the World Economy, 2, International Centre for Monetary and Banking Studies and CEPR.

Chatelain, J.B., Generale, A., Hernando, I., von Kalckreuth, U. and P. Vermeulen (2001): Firm Investment and Monetary Transmission in the Euro Area, ECB Working Paper No. 112.

Chinn, M.D. and G. Meredith (2005): Testing Uncovered Interest Parity at Short and Long Horizons During the Post-Bretton Woods Area, NBER Working Paper No. 11077

Chmielewski, T. (2003): Interest Rate Pass-Through in the Polish Banking Sector and Bank-Specific Financial Disturbances, paper presented at the ECB Workshop on Asset Prices and Monetary Policy, 11-12 December

Chmielewski, T. (2005): Bank Risks, Risk Preferences and Lending, National Bank of Poland, mimeo.

Choudhri, E.U. and D.S. Hakura (2001): Exchange Rate Pass-Through to Domestic Prices: Does the Inflationary Environment Matter? IMF Working Paper No. 194.

Choudhry, T. (1998): Another Visit to the Cagan Model of Money Demand: The Latest Russian Experience, Journal of International Money and Finance, $17,355-376$. 
Choudry. E.U., Faruqee, H. and D.S. Hakura (2005): Explaining the Exchange Rate Pass-Through in Different Prices, Journal of International Economics, 65, 349-374.

Chowdhury, A. and J. Fidrmuc (2004): Money Demand and Disinflation: The Experience of Selected CEECs, Oesterreichische Nationalbank, mimeo.

Christiano, Lawrence J., Eichenbaum, Martin and Evans, Charles (1996): Identification and the effects of monetary policy shocks, in: Financial Factors in Economic Stabilization and Growth, M. Blejer, Z. Eckstein, Z. Hercowitz, and L. Leiderman (eds), Cambridge University Press, pp. 36-74.

Coricelli, F., Jazbec, B. and I. Masten (2003): Exchange Rate Pass-Through in Acceding Countries: The Role of Exchange Rate Regimes, CEPR Discussion Paper No. 3894 and Journal of Banking and Finance (forthcoming).

Creel, J. and S. Levasseur (2005): Monetary Policy Transmission in the CEECs: How Important are the Differences with the Euro Area, OFCE Working Paper no. 2.

Crespo-Cuaresma, J., Égert, B. and T. Reininger (2004): Interest Rate PassThrough in NEW EU Member State: The Case of the Czech Republic, Hungary and Poland, William Davidson Institute Working Paper No. 671.

Croitoru, L. and M. E. Schaffer (2002): Measurement and Assessment of Soft Budget Constraints in Romania, National Bank of Romania, Occasional Paper No. 2.

Dabušinskas, A. (2003): Exchange Rate Pass-Through to Estonian Prices, Bank of Estonia Working Paper No. 10.

Dabušinskas, A. (2005): Money and Prices in Estonia, Bank of Estonia Working Paper No. 7.

Dale, S. and A. Haldane (1995): Interest Rats and the Channels of Monetary Transmission: Some Sectorial Estimates, European Economic Review, 39(9), 1611-1626.

Darvas, Zs. (2001): Exchange Rate Pass-Through and Real Exchange Rate in EU Candidate Countries, Deutsche Bundesbank Discussion Paper No. 10.

Darvas, Zs. (2005) Monetary Transmission in the New Members of the EU: Evidence from Time-Varying Coefficient Structural VARs, Corvinus University Budapest, mimeo.

DeBondt, G. (2002): Retail Bank Interest Rate Pass-Through: New Evidence at the Euro Area Level, ECB Working Paper No. 136.

Dedola, L. and F. Lippi (2000): The Monetary Transmission Mechanism: Evidence from the Industries of Five OECD Countries, CEPR Discussion Paper No. 2508.

DeGennaro, R.P. (2005): Market Imperfections, Federal Reserve Bank of Atlanta Working Paper No. 12.

Devereux, B. and J. Yetman (2003): Price-Setting and Exchange Rate PassThrough: Theory and Evidence, in: Proceedings of the conference Price Adjustments and Monetary Policy held at the Bank of Canada in November 2002, $347-71$.

Disyatat and Galati (2005): The effectiveness of foreign exchange intervention in emerging market counties: Evidence from the Czech koruna, BIS 
Working Papers No. 172.

Dobrynskaya, V. and D. Levando (2005): Exchange Rate Pass-Through Effect and Monetary Policy in Russia, paper presented at the BOFIT/CEFIR Workshop on Russian Macroeconomic and Financial Issues, Moscow, 8-9 April.

Driscoll, J.C. (2004): Does Bank Lending Affect Output? Evidence from the US States, Journal of Monetary Economics, 51, 451-471.

Égert, B. and L. Komarek (2005): Foreign Exchange Interventions and Interest Rate Policy in the Czech Republic: Hand in Glove? Czech National Bank Working Paper No 7. and Economic Systems, 30(2), 121-140.

Égert, B. and M. Lang (2005): Foreign Exchange Interventions in Croatia: Should We Give a Damn? Oesterreichische Nationalbank, mimeo.

Égert, B. and A. Morales-Zumaquero (2005): Foreign exchange regimes, foreign exchange volatility and trade performance in the CEECs, Osterreichische Nationalbank, Focus on European Economic Integration, 2005, No. 1., 76-97.

Égert, B., Crespo-Cuaresma, J. and T. Reininger (2006): Interest Rate PassThrough in Central and Eastern Europe: Reborn from Ashes to Pass Away? Oesterreichische Nationalbank, Focus on Europen Economic Integration No. 1.

Égert, B., Halpern, L. and R. MacDonald (2006): Equilibrium Exchange Rates in Transition Economies: Taking Stock of the Issues, Journal of Economic Surveys, 20(2), 257-324.

Ehrmann, M. and A. Worms (2001): Interbank Lending and Monetary Policy Transmission: Evidence for Germany, ECB Working Paper No. 73.

Ehrmann, M. and M. Fratzscher (2004): Taking Stock: Monetary Policy Transmission t Equity Markets, Journal of Money, Credit and Banking, 36(4), 719-737.

Ehrmann, M., Gambacorta, L., Pagés, J.M., Sevestre, P. and A. Worms (2001): Financial Systems and the Role of Banks in Monetary Policy Transmission in the Euro Area, ECB Working Paper No. 105.

Elbourne A. and J. de Haan (2005): Financial Structure and Monetary Policy Transmission in Transition Economies, Journal of Comparative Economics (forthcoming).

Engel, Ch. (2002): The Responsiveness of Consumer Prices to Exchange Rates and the Implications for Exchange Rate Policy: A Survey of a Few Recent New Open-Economy Macro Models, NBER Working Paper No. 8725.

Escriva, J.L. and A Haldane (1994): The Interest Rate Transmission Mechanism: Sectoral Estimates for Spain, Bank of Spain Working Paper No. 9414.

European Forecasting Network (2004): Monetary Transmission in Acceding Countries, Annex., 97-142.

Fama, E.F. (1985): What's Different about Banks? Journal of Monetary Economics, 15(1), 29-39.

Favero, C. and F. Giavazzi (2004): Inflation Targeting and Debt: Lessons from Brazil, NBER Working Paper 10390.

Favero, C.A., Giavazzi, F. and L. Flabbi (1999): The Transmission Mechanism of Monetary Policy in Europe: Evidence from Banks' Balance Sheet, NBER Working Paper No. 7231. 
Filardo, A. (2004): Monetary Policy and Asset Price Bubbles: Calibrating the Monetary PolicyTRade-Off, BIS Working Paper No. 155.

Frankel, J.A., Parsley, D.C. and S-J. Wei (2005): Slow Pass-Through Around the World: A New Import for Developing Countries, NBER Working Paper No. 11199 .

Gagnon, J.E. and J. Ihrig (2001): Monetary Policy and Exchange Rate Pass-Through, Board of Governors of the Federal Reserve System, International Finance Discussion Papers No. 704.

Gambacorta, L. (2004): How Do Banks Set Interest Rates? NBER Working Paper No. 10295.

Gambacorta, L. (2005): Inside the Bank Lending Channel, European Economic Review, forthcoming.

Gambacorta, L. and P.E. Mistrulli (2003): Bank Capital and Lending Behaviour: Empirical Evidence for Italy. Banca d'Italia Working Paper No. 486.

Ganev, G., Molnár, K., Rybiński, K. and P. Woźniak (2002): Transmisson Mechanism of Monetary Policy in Central and Eastern Europe, CASE Reports No. 52.

Gertler, M. and S. Gilchrist (1993): The Role of Credit Market Imperfections in the Monetary Transmission Mechanism: Arguments and Evidence, Scandinavian Journal of Economics, 95(1), 43-64.

Giordani, P. (2004): An Alternative Explanation of the Price Puzzle, Journal of Monetary Policy, 51(6), 1271-1296.

Goldberg, P. K. and M.M. Knetter (1997): Goods Prices and Exchange Rates: What have We Learned? Journal of Economic Literature, 35(3), 12431272 .

Golodniuk, I. (2005): Evidence on the Bank Lending Channel in Ukraine, paper presented at the Second Meeting of the UACES Study Group on Monetary Policy in Selected CIS Countries, Helsinki, 10-11 February, 2005.

Gross, D. B. and N.S. Souleles (2000): Consumer Responses to Changes in Credit Supply: Evidence from Credit Card Data, Wharton Financial Institutions Center Working Paper No. 4.

Gueorguiev, N. (2003): Exchange Rate Pass-Through in Romania, IMF Working Paper No. 130.

Hancock, D. and J.A. Wilcox (1998): The 'Credit Crunch' and the Availability of Credit to Small Businesses, Journal of Banking and Finance, 22, 983-1014.

Hannan, T.H and A.N. Berger (1991): Rigidity of Prices: Evidence from the Banking Industry, American Economic Review, 81(4), 938-945.

Hanson, M.S. (2004): The "Price Puzzle" Reconsidered, Journal of Monetary Economics, 51(7), 1385-1413.

Havrylchyk, O. and E. Jurzyk (2005): Does the Bank Lending Channel Work in a Transition Economy? A Case of Poland, European University Viadrina, mimeo.

Héricourt, J. (2005): Monetary Policy Transmission in the CEECs: Revisited Results Using Alternative Econometrics, University of Paris 1, mimeo.

Holub, T. (2004): Foreign Exchange Interventions Under Inflation Targeting: The Czech Experience, Czech National Bank Internal Research and Policy Note 
No. 1.

Horváth, Cs., Krekó J. and A. Naszódi (2004): Interest Rate Pass-Through: The Case of Hungay, National Bank of Hungary Working Paper No. 8.

Horváth, Cs., Krekó J. and A. Naszódi (2005): Is There a Bank Lending Channel in Hungary? National Bank of Hungary, mimeo.

Hurlin, C. and R. Kierzenkowski (2002): A Theoretical and Empirical Assessment of the Bank Lending Channel and Loan Market Disequilibrium in Poland, National Bank of Poland Materiały i Studia No. 22.

Hurlin, C. and R. Kierzenkowski (2003): Credit Markt Disequilibrium in Poland: Can We Find What We Expect? Non-Stationarity and the "Min" Condition, William Davidson Working Paper no. 581.

Jakab, M.Z. and M.A. Kovács (2003): Explaining the Exchange Rate PassThrough in Hungary: Simulations with the NIGEM model, National Bank of Hungary Working Paper No. 5.

Jarociński, M. (2005): Responses to Monetary Policy Shocks in the East and the West of Europe. A Comparison, University of Pompeu Fabra, mimeo.

Juks, R. (2004): The Importance of the Bank Lending Channel in Estonia: Evidence from Microeconomic Data, Bank of Estonia Working Paper No. 6.

Kakes, J. (1998): Monetary Transmission and Bank Lending in the Netherlands, University of Groningen, Research Report C30.

Kalra, S. (1998): Inflation and Money Demand in Albania, IMF Working Paper No. 101.

Kara, H., Küçük Tuğer, H., Özlale, Ü., Tuğer, B., Yavuz, D. and E.M. Yücel (2005): Exchange Rate Pass-Through in Turkey: Has It Changed and to What Extent? Central Bank of the Republic of Turkey Working Paper No. 4.

Kashyap, A.K. and J.C. Stein (1995): The Impact of Monetary Policy on Balance Sheets, Carnegie-Rochester Conference Series on Public Policy, 42, 15195.

Kashyap, A.K. and J.C. Stein (2000): What Do a Million Observations on Banks Say About the Transmission of Monetary Policy? American Economic Review, 90(3), 407-428.

Kashyap, A.K., Stein, J.C. and D.W. Wilcox (1993): Monetary Policy and Credit Conditions: Evidence from the Composition of External Finance, American Economic Review, 83(1), 78-98.

Kashyap, A.K., Stein, J.C. and D.W. Wilcox (1996): Monetary Policy and Credit Conditions: Evidence from the Composition of External Finance: Reply, American Economic Review, 86(1), 310-314.

Kierzenkowski, R. (2004): Le canal étroit du crédit et la transmission de la politique monétaire: Analyse théorique et application au cas de la Pologne, $\mathrm{PhD}$ dissertation, University of Paris - Dauphine.

Kierzenkowski, R. (2005a): The Multi-Regime Bank Lending Channel and the Effectiveness of the Polish Monetary Transmission During Transition, Journal of Comparative Economics, 33(1), 1-24.

Kierzenkowski, R. (2005b): Another View of the Bank Lending Channel Theory: The Bernanke and Blinder (1988) Model Revisited, Banque de France, mimeo. 
Kim, S. and N. Roubini (2000): Exchange Rate Anomalies n the Industrial Countries: A Solution with a Structural VAR Approach, Journal of Monetary Economics, 45(3), 561-586.

King, S. (1986): Monetary Transmission - Through Bank Loans or Bank Liabilities? Journal of Money, Credit and Banking, 18(3), 290-303.

Kishan, R.P. and T.P. Opieal (2000): Bank Size, Bank Capital and the Bank Lending Channel, Journal of Money, Credit and Banking, 32(1), 121-141.

Knell, M. and H. Stix (2003): How Robust Are Money Demand Estimations? A Meta-Analytical Approach, Oesterreichische Nationalbank Working Paper No. 81.

Kohler, M., Britton, E. and A. Yales (2000): Trade Credit and the Monetary Transmission Mechanism, Bank of England Working Paper No. 115.

Kokoszczyński, R. (1996): Monetary Policy in Hungary: Strategies, Instruments and Transmission Mechanism, in: in: Oesterreichische Nationalbank: Monetary Policy in Transition: Strategies, Instruments and Transmission Mechanisms, 162-166.

Korhonen, I. and P. Wachtel (2005): A Note on Exchange Rate PassThrough in CIS Countries, BOFIT Discussion Papers No. 2.

Kornai, J., E. Maskin and G. Roland (2003): Understanding the Soft Budget Constraint, Journal of Economic Literature, 41, 1095-1136

Kot, A. (2004): Does Banking Sector Competitiveness Affect Interest Rate Pass-Through? Paper presented at the $3^{\text {rd }}$ Macroeconomic Policy Research Workshop, 29-30 October, National Bank of Hungary

Köhler, M., J. Hommel and M. Grote (2005): The Role of Banks in the Transmission of Monetary Policy in the Baltics, Zentrum für Europäische Wirtschaftsforschung Discussion Paper No. 6.

Kuijs, L. (2002): Monetary Policy Transmission Mechanism and Inflation in the Slovak Republic, IMF Working Paper No. 80.

Ludvigson, S. (1998): The Channel of Monetary Transmission to Demand: Evidence from the Market for Automobile Credit, Journal of Money, Credit and Banking, 30(3), 365-383.

MacDonald, Ronald and Nagayasu, Jun (1999): The long-run relationship between real exchange rates and real interest rate differentials: A panel study, IMF Working Paper No. 37., March.

Maliszewski, W. (1999): VAR-ing Monetary Policy in Poland, CASE Studies\&Analyses No. 188.

Maliszewski, W. (2002): Monetary Policy in Transition: Structural Econometric Modelling and Policy Simulations, CASE Studies\&Analyses No. 246.

Maliszewski, W. (2003): Monetary Policy in Transition: Structural Econometric Modelling and Policy Simulations, CASE, mimeo

Markovic, B. (2004): Bank Capital Channels in the Monetary Transmission Mechanism, Bank of England, mimeo.

Mateut, S. (2004): Trade Credit and Monetary Policy Transmission, Journal of Economic Surveys, 19(4), 654-670.

Mateut, S., Bougheas, S. and P. Mizen (2003): Trade Credit, Bank Lending and Monetary Policy Transmission, European University Institute Working 
Paper No. 2.

Matousek, R. and N. Sarantis (2006): The Bank Lending Channel and Monetary Transmission in Central and Eastern Europe, 61st International Atlantic Economic Conference Berlin, 15-19 March 2006

McCallum, B.T. (1999): Analysis of the Monetary Transmission Mechanism: Methodological Issues, NBER Working Paper 7395.

McCarthy, J. (1999): Pass-Through of Exchange Rates and Import Prices to Domestic Inflation in Some Industrialised Economies, BIS Working Paper No. 79.

McKenzie M.D. (1999) The Impact of Exchange Rate Volatility on International Trade Flows, Journal of Economic Surveys, 13, 71-106.

Mihailov, A. (2005): Exchange Rate Pass-Through on Prices in US, German and Japanese Macrodata, University of Essex, mimeo.

Mihaljek, D. and M. Klau (2001): A Note on the Pass-Through from Exchange Rate and Foreign Price Changes to Inflation in Selected Emerging Market Economies, BIS Paper No. 8.

Miron, J., Romer, C. and D. Weil (1994): Historical Perspectives on the Monetary Transmission Mechanism, in G. Mankiw (ed.) Monetary Policy, University of Chicago Press, 263-306.

Mishkin, F S. (2001): The Transmission Mechanism and the Role of Asset Prices in Monetary Policy, NBER Working Paper No. 8617.

Modigliani (1971): Monetary Policy and Consumption,

Mojon, B. and G. Peersman (2001): A VAR Description of the Effects of Monetary Policy in the Individual Countries of the Euro Area, ECB Working Paper No. 92.

Morgan, D. (1998): The Credit Effects of Monetary Policy: Evidence Using Loan Commitments, Journal of Money, Credit and Banking, 30(1), 102-118.

Mussa (1986): Nominal Exchange Rate Regimes and the Behavior of Real Exchange Rates: Evidence and Implications. Carnegie-Rochester Conference Series on Public Policy 25, 117-214.

Neményi, J. (1996): Monetary Policy in Hungary: Strategies, Instruments and Transmission Mechanism, in: Oesterreichische Nationalbank: Monetary Policy in Transition: Strategies, Instruments and Transmission Mechanisms, 131-161.

Nickisch, S. (2005): The Interest Rate Pass-Through in Lithuania, Free University of Berlin, mimeo.

Nilsen, J.H. (2002): Trade Credit and the Bank Lending Channel, Journal of Money, Credit and Banking, 34(1), 226-53.

Oliner, S.D. and G.D. Rudebusch (1996): Monetary Policy and Credit Conditions: Evidence from the Composition of External Finance: Comment, American Economic Review, 86(1), 300-309.

Oomes, N. and F. Ohnsorge (2005): Money Demand and Inflation in Dollarised Economies: The Case of Russia, Journal of Comparative Economics (forthcoming)

Opiela, T.P. (1999): The Responsiveness of Loan Rates to Monetary Policy in Poland: The Effects of Bank Structure, National Bank of Poland Materials 
and Studies No 12.

Payne, J.E. (2003): Post Stabilisation Estimates of Money Demand in Croatia: Error Correction Model Using the Bounds Testing Approach, Applied Economics, 35(16), 1723-1727.

Peek, J. and E. Rosengren (1995): The Capital Crunch: Neither a Borrower nor a Lender be, Journal of Money, Credit and Banking, 27(3), 625-638.

Peel, D., Sarno, L. and M.P. Taylor (2001): Nonlinear Mean Reversion in Real Exchange Rates: Towards a Solution to the Purchasing Power Parity Puzzles, International Economic Review, 42(4), 1015-1042.

Peersman, G. and F. Smets (2001): Are the Effects of Monetary Policy in the Euro Area Greater in Recessions than in Booms? ECB Working Paper No. 52.

Peersman, G. and F. Smets (2002): The Industry Effects of Monetary Policy in the Euro Area, ECB Working Paper No. 165.

Pelipas, I. (2005): Money Demand and Inflation in Belarus: Evidence from Cointegrated VAR, paper presented at the Second Meeting of the UACES Study Group on Monetary Policy in Selected CIS Countries, Helsinki, 10-11 February, 2005.

Pizarro-Barceló, R. (2004): A Bank Lending Channel of Monetary Policy in Spain: Evidence from Bank Balance Sheet, University of Valencia, mimeo.

Pruteanu, A. (2004): The Role of Banks in the Czech Monetary Policy Transmission Mechanism, CNB Working Paper No. 3.

Rabanal, P. (2003): The Cost Channel of Monetary Policy: Further Evidence for the United States and the Euro Area, IMF Working Paper No 149.

Ramey, V. (1993): How Important is the Credit Channel in the Transmission of Monetary Policy? Carnegie-Rochester Conference Series on Public Policy, 39, $1-45$.

Rezessy, A. (2005): Estimating the Immediate Impact of Monetary Policy Shocks on the Exchange Rate and Other Asset Prices in Hungary, National Bank of Hungary, mimeo.

Rodzko, R. (2004): Exchange Rate Pass-Through in the New EU Member States: Evidence from Micro Data, Bank of Lithuania, mimeo.

Romer, C. and D. Romer (1989): Does monetary policy matter? A new test in the spirit of Friedman and Schwartz, NBER Macroeconomic Annual, Vol. 4, pp. 121-170.

Romer, C. and D. Romer (1990): New Evidence on the Monetary Transmission Mechanism, Brookings Papers on Economic Activity, 1, 149-198.

Sander, H. and S. Kleimeier (2002): Asymmetric Adjustment of Commercial Bank Interest Rates in the Euro Area: An Empirical Investigation into Interest Rate Pass-Through, Kredit und Kapital, 35(2), 161-192.

Sander, H. and S. Kleimeier (2004a): Convergence in Euro-Zone Retail Banking? What Interest Rate Pass-Through Tells Us about Monetary Policy Transmission, Competition and Integration, Journal of International Money and Finance, 23(3), 461-492.

Sander, H. and S. Kleimeier (2004b): Interest Rate Pass-Through in an Enlarged Europe: The Role of Banking Market Structure for Monetary Pol- 
icy Transmission in Transition Economies, University of Maastricht, METEOR Research Memoranda No. 045.

Sarno, L. and M. P. Taylor (2001): Official Intervention in the Foreign Exchange Market:: Is It Effective, and, If So, How Does it Work? CEPR Discussion Paper No. 2690.

Schmitz, B. (2004): What Role Do Banks Play in Monetary Policy Transmission in EU Accession Countries? Paper presented at the $3^{\text {rd }}$ Macroeconomic Policy Research Workshop, 29-30 October, National Bank of Hungary

Sims, C.A. (1992): Interpreting the Macroeconomic Time Series Facts: The Effects of Monetary Policy, European Economic Review, 36(5), 975-1000.

Slavova, S. (2003): Money Demand During Hyperinflation and Stabilisation: Bulgaria, 1991-2000, Applied Economics, 35(11), 1303-1316.

Sløk, T. (2002): Money Demand in Mongolia: A Panel Data Analysis, IMF Staff Papers, 49(1), 128-135.

Soto, C. and J. Selaive (2003): Openness and Imperfect Pass-Through: Implications for the Monetary Policy, Central Bank of Chile Working Papers No. 216.

Taylor, J. (2000): Low Inflation, Pass-Through and the Pricing Power of Firms, European Economic Review, 44, 1389-1408. ???

Thakor, A.V. (1996): Capital Requirements, Monetary Policy and Aggregate Bank Lending: Theory and Empirical Evidence, Journal of Finance, 51(1), 279324.

Tieman, A. (2004): Interest Rate Pass-Through in Romania and Other Central European Economies, IMF Working Paper No 211.

Tillers, I. (2004): Money Demand in Latvia, Bank of Latvia Working Paper No. 3.

Tobin, James (1969): A General Equilibrium Approach to Monetary Theory, Journal of Money, Credit and Banking. Vol. 1 No. 1, pp.15-29.

Tornell, A. and F. Westermann (2002): The Credit Channel in Middle Income Countries, NBER Working Paper No. 9355.

Van den Heuvel, S. J. (2002): The Bank Capital Channel of Monetary Policy, University of Pennsylvania, mimeo.

Várhegyi, É (2003): Bankverseny Magyarországon (Competition in the Hungarian banking sector), Közgazdasági Szemle, 50, 1027-1048.)

Világi, B. and J. Vincze (1998): The Interest Rate Transmission Mechanism in Hungary, 1991-1995, in: L. Halpern and Ch. Wyplosz (eds): Hungary: Towards a Market Economy, Cambridge, Cambridge University Press, 54-84.

Vonnák, B. (2005): Estimating the Effect of Hungarian Monetary Policy within a Structural VAR Framework, National Bank of Hungary Working Paper No. 1.

Wang, H. (2001): Production Smoothing When Bank Loan Supply Shifts: The Role of Variable Capacity Utilization, Journal of Money Credit and Banking, 33(3), 749-766.

Weth, M.A. (2002): The Pass-Through from Market Interest Rates to Bank Lending Rates in Germany, Deutsche Bundesbank Discussion Paper No. 11. 
Wróbel, E. (2001): The Monetary Transmission Mechanism and the Structural Modelling of Inflation at the National Bank of Poland, BIS Papers No. 8., 232-242.

Wróbel, E. and M. Pawlowska (2002): Monetary Transmission in Poland: Some Evidence on Interest Rate and Credit Channels, National Bank of Poland, Materiały i Studia No. 24.

Yalçin, C., Bougheas, S. and P. Mizen (2004): The Impact of Firm-Specific Characteristics on the Response to Monetary Policy Actions, Central Bank of the Republic of Turkey Working Paper No. 7. 


\section{Annex A \\ Exchange Rate Pass-Through}

Table A1. Characteristics of Individual Studies

\begin{tabular}{|c|c|c|c|}
\hline Anthox & Combrie & Method & Feriod \\
\hline \multicolumn{4}{|c|}{ VAF Stadies } \\
\hline 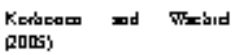 & $\begin{array}{l}\text { CEECS. CE. RONA } \\
\text { HR }\end{array}$ & 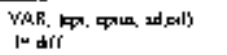 & $|m 0|-2004 \mid 1$. \\
\hline$G$ Zem a & 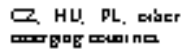 & 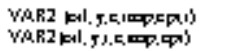 & 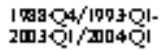 \\
\hline Blmar ad Bay o (2⿴囗十) & HR & 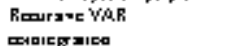 & $104 \mid-2001 \cdot 1$ \\
\hline Gurrogue= (MID) & Ro & Rmirs=e Ya.R & Im706-2m3al \\
\hline$B_{11202}[204$ & CEECI 3 & $C P I, P P($ mand $=$ YaR & $103 \cdot 1-2003 \cdot 0$ \\
\hline \multicolumn{4}{|c|}{ singl-Equatin } \\
\hline $\begin{array}{l}\text { Detryakep ad Lromdo } \\
\text { D03y }\end{array}$ & Ruma & 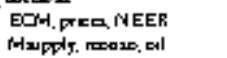 & $105 \cdot 1-200 \cdot 12$ \\
\hline Seav mad Cxter (2003) & HU, DL & $\begin{array}{l}\text { Rull co difícrerea, } \\
\text { IUV, NEER }\end{array}$ & $|\pi 9 Q|-\pi \mathbb{R} \mid \cdot Q^{4}$ \\
\hline Capa mod Goldtorg (20) & 므 HU DL & Impon 지요 & ITSQI-IDgPQ4 \\
\hline 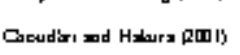 & $\begin{array}{l}\text { PECDas } \\
\text { il muairia }\end{array}$ & 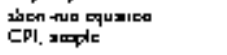 & $100.2 m 0$ \\
\hline & HU RONA & & \\
\hline $\begin{array}{l}\text { Derreux ad Yamer } \\
\text { Rad\}) }\end{array}$ & $\begin{array}{l}\text { ID muana } \\
\text { PC. HU. PL } \\
\text { RQVisi }\end{array}$ & & \\
\hline Nidadas) & LT & $\begin{array}{l}\text { Rra difif } \\
\text { CPI, pPI, ar: }\end{array}$ & ImLQI-304Q| \\
\hline Dutrerke ad Kl|w pWls & $\begin{array}{l}13 \text { muaria } \\
\text { CEET3 }\end{array}$ & "نام & $100-2 m 0$ \\
\hline 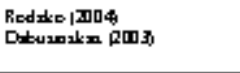 & $\begin{array}{l}\text { CEEC } \\
\mathrm{EE}\end{array}$ & 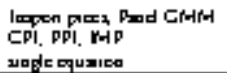 & $100 Q 1-2003 Q 4$ \\
\hline \multicolumn{4}{|c|}{ Adju tment to Equing inm } \\
\hline Den an 20015 & 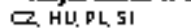 & $G_{R A}+Y a R$ & $1 m 20 \mid-20 m Q 3$ \\
\hline
\end{tabular}


Table A2. Exchange Rate Pass-Through Estimates for Import Prices (Import Unit Value Indices)

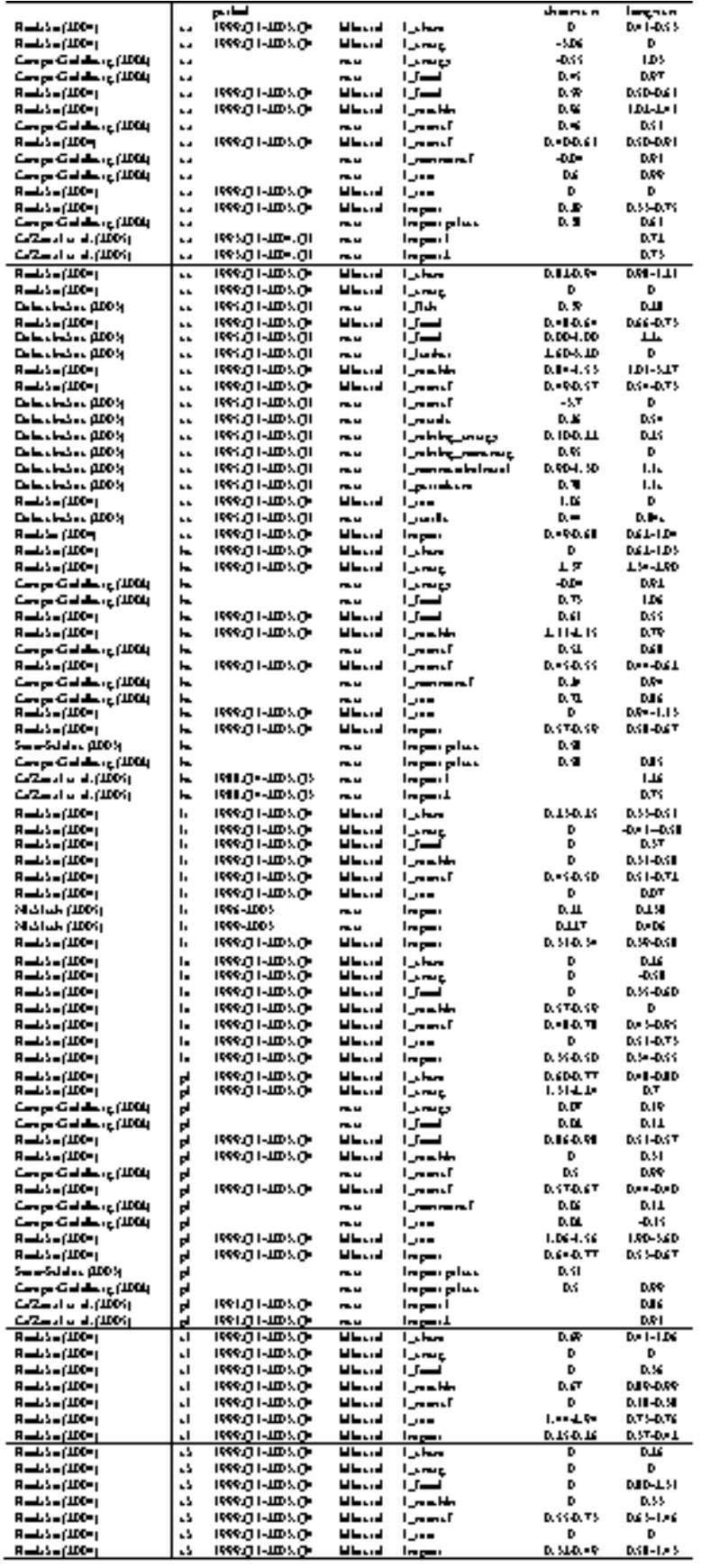


Table A2. Exchange Rate Pass-Through Estimates for the PPI

\begin{tabular}{|c|c|c|c|c|c|c|}
\hline & & Priad & & & atori-mb & loog-nua \\
\hline $81202 \sqrt[2004]{ }$ & $\mathrm{Eg}$ & $1003 \cdot 1.197 \cdot 06$ & वा & $\nabla F$ & & 125 \\
\hline$B_{1}=22004$ & $\mathrm{~kg}$ & ID97-07-30306 & वा & DV & & 063 \\
\hline$B_{1}=202004$ & $=$ & $1003 \cdot 1.107 \cdot 12$ & वा & Fe & & Qu \\
\hline$B_{1}=22004$ & ㅁ & | $908 \cdot 01-30306$ & प्य & Fe & & 022 \\
\hline$B_{1}=2 \sqrt[2004]{2}$ & ш & $1003 \cdot 1.197 \cdot 12$ & ד्य & ov & & 103 \\
\hline$B_{1}=22004$ & ш & 1979.01-300306 & שם & DV & & Q \\
\hline Dtuyarkn (301) & ш & $\mid$ & ד्य & DV & 0 & 0 \\
\hline Dtzuyazkn (MDO3) & ш & $1005 \cdot Q 1-2003 \cdot Q 1$ & वा & VV_demc| & 041 & IS7e \\
\hline Dtuyalkn (301) & ш & $1005 \cdot Q 1-2003 \cdot Q \mid$ & वा & pajod & 007 & $137 \mathrm{e}$ \\
\hline Dtuyazkn (3013) & ш & $1005 \cdot 01.2003 \cdot Q \mid$ & ד्ד & 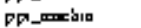 & 26 & $33 \mathrm{e}$ \\
\hline Dtuyarkn (3013) & ш & | & 吅 & DV_manoul & 014020 & $046-0<0$ \\
\hline Dtuyazkn (3013) & ш & $|805 \cdot Q 1.2003 \cdot Q|$ & वा & DV_monul & OS7 & IIe \\
\hline Dtevualkn |M03) & ш & $1005 \cdot Q 1-2003 \cdot Q 1$ & वाप & DV_arule & וקו & 413 \\
\hline Bllmrir and Bcose (2002) & ar & $1004 / .2 \mathrm{O}|\cdot|$ & वा & $\mathrm{DC}$ & 0 & 0 \\
\hline$B_{1}=22004$ & ar & 1908.01-30306 & ד & DV & & 034 \\
\hline$B_{1}=2,2004$ & du & $1803 \cdot 1.201 \cdot 03$ & प्त & DF & & 075 \\
\hline$B_{1}=2004$ & bu & 2001.0430306 & 吅 & Fe & & 030 \\
\hline Nidizd DO0S) & $\mathrm{t}$ & $1006-2003$ & वा & FV & 0003 & 0303 \\
\hline Nidazd p005) & It & I & ד्य & DV & Sסום & 0222 \\
\hline$B_{1}=202004$ & I. & $1903 \cdot 1.167 \cdot 12$ & वा & We & & III \\
\hline$B_{1}=2 \quad 2004$ & I" & 1098.01-30306 & ד्य & DV & & Q S \\
\hline$B_{1}=22004$ & I. & $1904.1 .197 \cdot 12$ & वा & DV & & 0 \\
\hline$B_{1}=2,2004$ & I. & | $1009 \cdot 01-30306$ & ד & pe & & 033 \\
\hline$B_{1} \equiv 2 \sqrt{2004}$ & mak & $1004.1 .1 \mathrm{ma} \cdot 12$ & वाप & DV & & 0 \\
\hline$B_{1}=22004$ & me & 1090.01-200306 & वा & 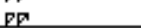 & & 0 \\
\hline$B_{1}=22004$ & $\infty$ & $1003 \cdot 1.100 .12$ & वा & $\nabla V$ & & 064 \\
\hline$B_{1}=20004$ & $\infty$ & $2000 \cdot 01$-30306 & aा & $\mathrm{pr}$ & & Q SS \\
\hline Guxx/guis (2003) & $\mathrm{rod}$ & |907-01-3030| & uad & DV & 032 & $0 \mathrm{Gl}$ \\
\hline Guxrguir [2003) & $\mathrm{red}$ & | & banka & $\mathrm{FT}$ & S3 & 07 \\
\hline Gurerguir [2003) & $\operatorname{rem}$ & | & are & FV & كاם & םSS \\
\hline Gurerguir (2003) & $\mathrm{red}$ & 2000・ו1I-3003010 & uad & DV & 014 & 044 \\
\hline Guxrguir [2003) & $\mathrm{rem}$ & 2000.11-303010 & bana & DV & 022 & 041 \\
\hline Gucrguir [2003) & $\operatorname{rog}$ & 2000-II-300301 & are & DV & 013 & 024 \\
\hline$B_{1}=202004$ & $\mathrm{red}$ & $1803 \cdot 1.197 \cdot 12$ & वा & $\mathrm{Fr}$ & & 074 \\
\hline 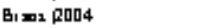 & $\operatorname{red}$ & IDD9.01-30306 & वा & DV & & 026 \\
\hline Detr-Lremedo & ru & & वा & DV & 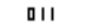 & 023 \\
\hline Detr-Lremedo & ru & & ד्य & PV_கரm & 0I & 023 \\
\hline Dete-Lromedo & ru & & ד्य & DV_- & 004 & 012 \\
\hline Dete-Lremedo & ru & & वा & DV_שerg & 003 & 017 \\
\hline Dete-Lremedo & ru & & प्य & Dajeded & 026 & OS \\
\hline Dete-Lremedo & ru & & वा & DV_fuel & 003 & 022 \\
\hline Detr-Lremedo & ru & & वा & 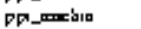 & 012 & 024 \\
\hline Detr-Lremedo & ru & & वा & 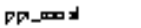 & 0 & 0 \\
\hline Dete-Lromedo & ru & & वा & DV_-000_farteu 2 & 022 & 077 \\
\hline Dete-Lremedo & ru & & वा & DF_arule & 013 & 032 \\
\hline Detr-Lromedo & ru & & वा & PV_trei & 006 & 041 \\
\hline$B_{1}=2 \sqrt[2004]{ }$ & ע & $1003 \cdot 1-197 \cdot 12$ & वाप & DV & & 100 \\
\hline$B_{1}=2,2004$ & у & | & वा & $\mathrm{pa}$ & & 047 \\
\hline$B_{1}=20004$ & $\mathbf{l k}$ & $1003 \cdot 1.102 \cdot 00$ & वा & $\mathrm{FV}$ & & 口 \\
\hline$B_{1}=20004$ & 点 & $1809 \cdot 10-30306$ & (ם & $\mathrm{PF}$ & & $0 S$ \\
\hline
\end{tabular}


Table A2. Exchange Rate Pass-Through Estimates for the CPI

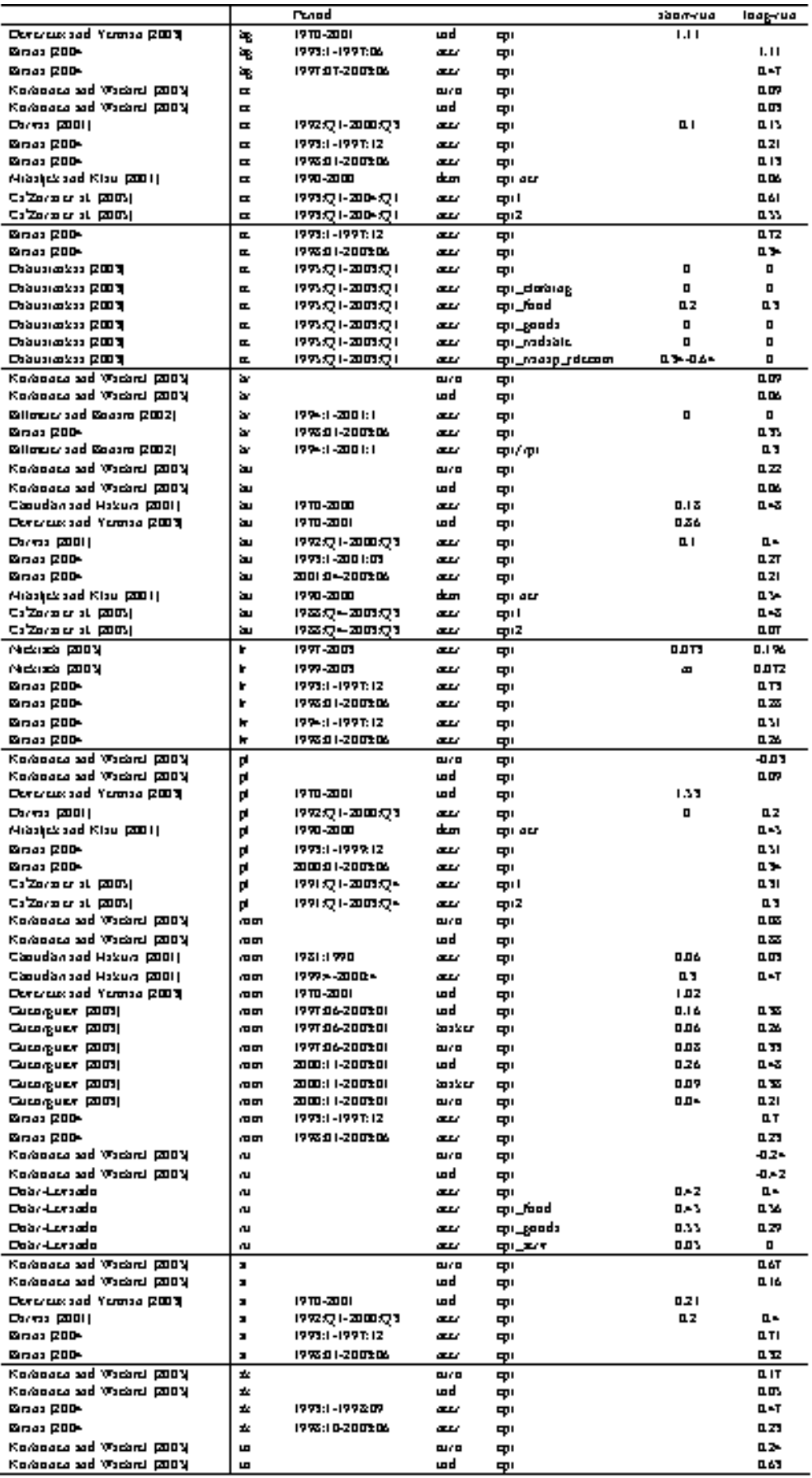




\section{Credit Channel in Transition Economies}

Table A3. Summary of Studies Relating to the Credit Channel

in Transition Economies

\begin{tabular}{|c|c|c|c|c|c|c|}
\hline Ainthor & Country & Period & EM & MP & MAA & No. of banks \\
\hline Juگs(2004) & $\mathrm{EE}$ & $1906-2004, Q$ & GMM & EURIBOR, 3M & $\mathrm{BA}$ & 5 \\
\hline Schrritz (2004) & CEEC8 & $1906-2001, \mathrm{~A}$ & OLS & MMR, EURIBOR & No & 100 \\
\hline Golodnink (2005) & UA & $1908-2003, \mathrm{~A}$ & IV & & & 149 \\
\hline Pruteanu (2004) & $\mathrm{CR}$ & $1906-2001, Q$ & GMM & 2 Wi no no nte & $\mathrm{BA}$ & 32 \\
\hline Havrylehyi and Jurzjk (2005) & PL & $1907-2002, Q$ & GMM & MMR; German (EUR) MMUR & $\mathrm{BA}$ & 67 \\
\hline Wróbel and Pawroske (2002) & PL & $1097-2001, Q$ & NA & $\mathrm{NA}$ & NA & NA \\
\hline Köhler et al (2005) & B3 & $1907-2004, \mathrm{~A}$ & OLS & EURIBOR, $3 \mathrm{M}$ & NA & 36 \\
\hline Matourek and Saratri் (2006) & CEEC8 & $1994-2003, \mathrm{~A}$ & GMM & MMR & & \\
\hline Chmiekwshi (2005) & PL & $1907-2004, Q$ & GMM & WIB OR 1MF; MCI (RIR and FX) & & \\
\hline
\end{tabular}

Notes: EE, CR, PL and UA refer to Estonia, the Czech Republic, Poland and Ukraine. CEEC 8 includes CEEC $5+3$ Baltic countries. MMR $=$ money market rate.

Table A4. Summary of VAR Studies

\begin{tabular}{|c|c|c|c|}
\hline Aufier & Counfry /Period & VAR & $\begin{array}{r}\text { Variables } \\
\end{array}$ \\
\hline $\begin{array}{l}\text { Amos tova - Hurrúk } \\
(2004)\end{array}$ & $\begin{array}{l}C Z, \quad 1093: Q 1-2003: Q 4 \\
1908: Q 1-2003: Q 4\end{array}$ & VAR & $\mathrm{I}, \mathrm{E}, \mathrm{Y}, \mathrm{P}$ (core), $\mathrm{I}^{+}$ \\
\hline Bitans et al (2003) & LV, 1905:1-2002:3 & $\mathrm{VAR}$ & $\begin{array}{l}\text { E, Y(IP), P (PP I), } \\
\text { Exog: } I^{+}, Y\left(I^{*}\right)^{+}\end{array}$ \\
\hline Creel - Levasseur (2005) & $\begin{array}{l}\mathrm{CZ}, \mathrm{HU}, \mathrm{PL} \\
109: 1-2004: 4\end{array}$ & VAR in level, recursine & $\begin{array}{l}\text { I,E(NEEF), Y(IP),P,Cre dit, ML } \\
\text { Exog I*, Y(IP),P (euro area) }\end{array}$ \\
\hline Darvas (2005) & $\begin{array}{l}\mathrm{CZ}, \mathrm{HU}, \mathrm{PL} \\
1904: \mathrm{Q}^{4} 2004: \mathrm{Q3}^{3}\end{array}$ & $\begin{array}{l}\mathrm{VAR}, \mathrm{k}=1 \text {, contermporane ous } \\
\text { restrictions., T'VC VAR }\end{array}$ & $\mathrm{I}, \mathrm{Q}, \mathrm{Y}, \mathrm{P}$ \\
\hline EFN (2004) & $\begin{array}{l}\text { CEEC5, B3 } \\
1903 / 1095: Q 1-2002: Q 2\end{array}$ & VAR in bovel, recuxise & $\begin{array}{l}\text { CEEC5: } \mathrm{I}, \mathrm{Y}, \mathrm{Q}, \mathrm{P}, \mathrm{l} 2 \\
\text { Ex og: } \mathrm{I}^{+}, \mathrm{Y}^{+}, \mathrm{P}^{+} \text {(euro area) } \\
\text { B3: } \mathrm{I}^{+}, \mathrm{Y}, \mathrm{P}, \mathrm{ML} \\
\text { Exog: } \mathrm{Q}, \mathrm{Y}^{+}, \mathrm{P}^{+}\end{array}$ \\
\hline $\begin{array}{l}\text { Elboume } \quad-\quad \text { deHan } \\
(2005)\end{array}$ & CEEC10 & $\mathrm{VAR}$, level & \\
\hline Ganev et al (2002) & CEEC8, BG.ROM & VAR, genemlised IR & $\begin{array}{l}\mathrm{I}, \mathrm{E}, \mathrm{Y}(\mathrm{IP}), \mathrm{P}(\mathrm{core}) \\
\text { Ex:ogY (IP) }+\mathrm{P}(\mathrm{PPI})+, \mathrm{I}^{+} \text {(euro } \\
\text { area) }\end{array}$ \\
\hline Héricount (2005) & $\begin{array}{l}\text { CEEC5, EE, } \\
1995: 1-2004: 9\end{array}$ & $\mathrm{VAR}$, level, recursine, $\mathrm{K}=3$ & I,E, Y(IP), Y(GDF), P, Credit \\
\hline Jarocirs li (2004) & CEEC5+Rom & VAR, level, Bajesian & $\mathrm{I}, \mathrm{E}, \mathrm{Y}(\mathrm{IP}), \mathrm{P}$ \\
\hline Kü̈s (2001 & $S K, 1993: 3-2000: 12$ & $\mathrm{VECM}$ & $\begin{array}{l}\mathrm{I}(\mathrm{Y}), \mathrm{E}(\mathrm{DEM}), \mathrm{Y}, \mathrm{P} \text { (core), ULC, } \\
\mathrm{ML}, \mathrm{Y}\end{array}$ \\
\hline Malisewsli (1999) & $\begin{array}{l}\text { PL } \\
1903: 01-1909: 04\end{array}$ & VAR in level, k=6, zero res triction & $\begin{array}{l}\text { Exog, } \mathrm{P}^{*}, \text { oil, regprice, fic } \\
\mathrm{I}, \mathrm{E}, \mathrm{Y}(\mathrm{IP}), \mathrm{P}\end{array}$ \\
\hline Maliszewshi (2002) & $\begin{array}{l}C Z, P L \\
1903: 1-2002: 4\end{array}$ & $\begin{array}{l}\text { VAR in level, } \mathrm{k}=6 \text {, Bayerin, } \\
\text { period split in two samples }\end{array}$ & $\mathrm{I}, \mathrm{E}, \mathrm{Y}(\mathrm{IP}) ; \mathrm{P}$ \\
\hline Maliszewshi (2002) & $\begin{array}{l}C Z, P L \\
1993: 1-2002: 4\end{array}$ & $\begin{array}{l}\text { VAR in level, } \mathrm{k}=6 \text {, Bayesin, } \\
\text { period split in two samples }\end{array}$ & I, E, Y (IP);P,EMIII \\
\hline Vorurák (2005) & $\mathrm{HU}, 1992: \mathrm{Q} 2-2003: \mathrm{Q}^{4}$ & VAR in level, altemative ident & $\mathrm{I}, \mathrm{E}, \mathrm{Y}, \mathrm{P}$ \\
\hline Wiróbel (2001) & PL, 1995:1-200:12 & $\mathrm{VAR}, \mathrm{CEE}$ & $\begin{array}{l}\text { I, Y(IP), credit-to-GDP, retail } \\
\text { sales, real unges, } \mathrm{M} 2\end{array}$ \\
\hline
\end{tabular}

Notes: $\mathrm{I}=$ interest rate; $\mathrm{E}=$ exchange rate, $\mathrm{Y}(\mathrm{IP})=$ output(industrial production), $\mathrm{P}=$ inflation. 


\section{Annex B}

Table B1. Factors Amplifying or Attenuating the Interest Rate Pass-Through, 2004

\begin{tabular}{|c|c|c|c|c|c|c|c|c|c|c|c|c|c|c|}
\hline & \multicolumn{5}{|c|}{ CEE5 } & \multicolumn{3}{|c|}{ B3 } & \multicolumn{3}{|c|}{ SEE } & \multicolumn{3}{|c|}{ EURO AREA } \\
\hline & $c z$ & HU & FL & $\mathrm{sK}$ & SI & EE & LV & LT & $\mathrm{BG}$ & $\mathrm{HR}$ & $\mathrm{RO}$ & EUR & MAX & MIN \\
\hline \multicolumn{15}{|c|}{ MACROECONOMY } \\
\hline Irflation (\%) & 2.6 & 6.8 & 3.6 & 7.5 & 3.7 & 3.0 & 6.2 & 1.1 & 6.1 & 2.1 & 11.9 & 2.2 & 3.1 & 0.2 \\
\hline Mar volatility & 0.75 & 1.92 & 1.88 & 1.37 & 1.23 & 0.54 & 0.41 & 0.60 & 0.95 & & 5.10 & 0.46 & & \\
\hline GDP grousth (\%) & 4.4 & 4.6 & 5.3 & 5.5 & 4.2 & 7.8 & 8.3 & 7.0 & 5.6 & 3.8 & 8.3 & 2.1 & 4.7 & 1.2 \\
\hline \multicolumn{15}{|l|}{ Frarcial de pth } \\
\hline Frivate ere dit to GDP' & 0.30 & 0.38 & 0.28 & 0.35 & 0.39 & 0.29 & 0.29 & 0.17 & 0.22 & 0.50 & 0.08 & 1.02 & 1.52 & 0.61 \\
\hline \multicolumn{15}{|c|}{ BANKING SECTOR } \\
\hline \multicolumn{15}{|l|}{ Concertration } \\
\hline -He firdahl index & 1103 & 795 & 692 & 1154 & 1425 & 3887 & 1021 & 1854 & NA & NA & NA & 966 & 2680 & 178 \\
\hline-51 agest barls (in total asset $\%$ ) & 64.0 & 527 & 50.2 & 66.5 & 64.1 & 98.6 & 62.4 & 78.9 & $47.0^{2}$ & $58.0^{0}$ & $66.0^{2}$ & 52.9 & 84.3 & 22.1 \\
\hline \multicolumn{15}{|l|}{ Fo reign b arks } \\
\hline Charge ix xum bes 1995-2003 & 3 & 8 & 28 & -2 & 0 & -1 & -1 & 7 & 22 & 18 & 13 & & & \\
\hline$\%$ in total asset ir 2003 & 96.0 & 83.3 & 67.8 & 96.3 & 36.0 & 97.3 & 95.6 & 47.2 & 86.0 & 910 & & & & \\
\hline \multicolumn{15}{|l|}{ State oumership (\% in total) } \\
\hline 1995 & 17.6 & 49 & 71.7 & 61.2 & 41.7 & 9.7 & 9.9 & 61.8 & NA & 519 & 84.3 & & & \\
\hline 2003 & 3.0 & 7.4 & 25.7 & 1.5 & 12.8 & 0.0 & 4.1 & 0.0 & 0.4 & 3.4 & 40.6 & & & \\
\hline \multicolumn{15}{|l|}{ Ead lo ars (\% in total) } \\
\hline 1995 & 26.6 & ra & 23.9 & 41.3 & 9.3 & 2.4 & 19 & 17.3 & 12.5 & 129 & 37.9 & & & \\
\hline 2003 & 5.0 & 3.8 & 25.1 & 9.1 & 9.4 & 0.5 & 1.5 & 2.6 & 4.4 & 9.4 & 1.6 & & & \\
\hline \multicolumn{15}{|l|}{ Earuk li quidity } \\
\hline Eark capitalisation & & & & & & & & & & & & & & \\
\hline
\end{tabular}

Source: Inflation and GDP growth: Eurostat/NewCronos, MM volatility is money market volatility based on the relative standard deviation of monthly observations for 1-month money market interest rates from 2002 to 2004. Private credit to GDP: World Bank Development Indocators (WDI) 2005, banking sector concentration: ECB (2005): EU Banking Structures, October, except for Bulgaria, Croatia and Romania: WDI 2005. Data on foreign banks, state ownership and bad loans are obtained from the EBRD Transition Report (2004)

$a_{2003}$

Table B2. Factors Amplifying or Attenuating the Exchange Rate Pass-Through

\begin{tabular}{|c|c|c|c|c|c|c|c|c|c|c|c|c|}
\hline & \multicolumn{5}{|c|}{ CEE5 } & \multicolumn{3}{|c|}{$\mathbf{B 3}$} & \multicolumn{3}{|c|}{ SEE } & \multirow{2}{*}{$\begin{array}{c}\text { EUR } \\
\text { EUR }\end{array}$} \\
\hline & $\subset$ & $\mathrm{HU}$ & PL & SK & SI & $\mathrm{EE}$ & LV & LT & $\mathrm{BG}$ & $\mathrm{HR}$ & RO & \\
\hline \multicolumn{13}{|c|}{ Composition effect (p.p.) } \\
\hline & 20.1 & 19.4 & 12.4 & 30.9 & 5.5 & NA & NA & NA & 20.3 & 22.2 & 24.0 & NA \\
\hline \multicolumn{13}{|c|}{ Macroeconomic environument } \\
\hline Level of inflation & 2.6 & 6.8 & 3.6 & 7.5 & 3.7 & 3.0 & 6.2 & 1.1 & 6.1 & 2.1 & 11.9 & 2.2 \\
\hline Inflation volatility & 1.42 & 1.11 & 1.56 & 2.35 & 1.66 & 1.45 & 2.10 & 1.63 & 2.47 & NA & 5.00 & 0.24 \\
\hline FX voh tility & 0.06 & 0.06 & 0.08 & 0.02 & 0.01 & 0.00 & 0.04 & 0.02 & 0.00 & 0.02 & 0.08 & 0.08 \\
\hline Exchnge nat regime & $\mathbf{M F}$ & P15 & FF & MF & $\mathrm{P}$ & $\mathrm{CB}$ & P & $\mathrm{CB}$ & $\mathrm{CB}$ & MF & MF & - \\
\hline Country size (EUR Mrd, 2004) & 78.4 & 68.9 & 202.5 & 25.7 & 23.5 & 7.5 & 9.8 & 14.9 & 16.6 & 24.2 & 48.4 & 9222.6 \\
\hline
\end{tabular}

Sources: WIIW Handbook of Statistics 2005, New Cronos/Eurostat.

Notes: Composition effect is measured as an increase in the share of manufactured goods in total imports between 1990 and 2004 (except for Slovakia: 1991-2004; Bulgaria: 1992-2004; Romania: 1993-2004. Inflation and FX volatility are based on the standard deviation of monthly observations for year-on year changes in the inflation and the exchange rate (EUR) from 2002 to 2004.

$\mathrm{MF}=$ managed float, $\mathrm{FF}=$ free float, $\mathrm{P}=$ tight peg, $\mathrm{P} 15=$ peg with a band of $+/-15 \%, \mathrm{CB}=$ currency board 
Table B3. Factors Influencing the Asset Price Channel

\begin{tabular}{|c|c|c|c|c|c|c|c|c|c|c|c|c|c|c|}
\hline & \multicolumn{5}{|c|}{ CEE5 } & \multicolumn{3}{|c|}{ B3 } & \multicolumn{3}{|c|}{ SEE } & \multicolumn{3}{|c|}{ EURO AREA } \\
\hline & $c z$ & $\mathrm{HU}$ & PL & $\mathrm{s}$ & SI & EE & LV & $\mathrm{LT}$ & EG & $\mathrm{CR}$ & $\mathrm{RO}$ & EUR & MAX & $\mathrm{MLN}$ \\
\hline \multicolumn{15}{|c|}{ Stock markets - 2003} \\
\hline Capitalization of of $\mathrm{CDPS}$ ) & 18.3 & 17.4 & 15.3 & 7.1 & 20.7 & 2.1 & 8.1 & 12.9 & 6.3 & 16.7 & 8.8 & 54.4 & 96.3 & 17.2 \\
\hline$e$ d to $C D P$ & 9.6 & 10.0 & 4.1 & 2.0 & 2.6 & 0.4 & 1.3 & 1.1 & 1.0 & 0.8 & 0.8 & 48.8 & 111.8 & 4.3 \\
\hline \multicolumn{15}{|c|}{ Bond mankets -2003} \\
\hline Fin uate bord mas ket capitalization & 7.2 & 3.4 & & NA & NA & NA & NA & NA & NA & NA & NA & 32.0 & 56.6 & 0.4 \\
\hline Fublic bord mar ket eapitalizati on & 51.5 & 40.9 & 20.1 & NA & NA & NA & NA & NA & NA & NA & NA & 53.2 & 97.1 & 20.1 \\
\hline to tal debtisusarce by rost fix corp & 0.3 & 0.0 & 6.0 & NA & 0.9 & 0.6 & NA & NA & NA & NA & NA & 12.9 & 50.4 & 0.6 \\
\hline \multicolumn{15}{|c|}{ Domestic investment fun ds } \\
\hline Inves tment furde & 4.3 & 5.4 & 4.7 & 5.0 & 8.1 & 3.5 & 0.5 & NA & NA & NA & NA & 51.3 & 202.5 & 9.5 \\
\hline Persion furt & 3.7 & 6.5 & 7.9 & NA & 2.0 & 1.9 & 0.4 & 0.1 & NA & NA & NA & 12.4 & 106.9 & 0.0 \\
\hline
\end{tabular}

Source: WDI (2004), ECB (2005)

Table B4. Factors Amplifying or Attenuating the Credit Channel

\begin{tabular}{|c|c|c|c|c|c|c|c|c|c|c|c|}
\hline & \multicolumn{5}{|c|}{ CEE5 } & \multicolumn{3}{|c|}{ B3 } & \multicolumn{3}{|c|}{ SEE } \\
\hline & $c z$ & HU & PL & $5 \mathrm{~K}$ & SI & EE & LV & L'T & $\mathrm{BG}$ & $\mathrm{CR}$ & مמת \\
\hline \multicolumn{12}{|c|}{ FIRST STAGE } \\
\hline \multicolumn{12}{|l|}{ Exoling sector } \\
\hline Concertration & $\mathrm{WJ}$ & $\mathrm{s}$ & $\mathrm{s}$ & $\mathrm{WJ}$ & Wi & $\mathrm{Wi}$ & $\mathrm{Wi}$ & $\mathrm{Wi}$ & $\mathrm{Wi}$ & & \\
\hline $\begin{array}{l}\text { Foreign barks/ } \\
\text { retw or k / small barks }\end{array}$ & $\mathrm{Wj}$ & $\mathrm{WJ}$ & $\mathrm{W}$ & WJ & $\mathrm{S}$ & $\mathrm{Wi}$ & $\mathrm{WJ}$ & Wi & $\mathrm{WJ}$ & $\mathrm{Wi}$ & W \\
\hline Gou. irw olv emert & $S$ & $\mathrm{WJ}$ & $\mathrm{S}$ & $\mathrm{WJ}$ & $\mathrm{S}$ & $\mathrm{s}$ & $\mathrm{s}$ & $S$ & $S$ & $\mathrm{~S}$ & W \\
\hline \multicolumn{12}{|l|}{ Latin pantionso } \\
\hline FX loars & $s$ & Wi & W & $\mathrm{Wi}$ & W & $\mathrm{Wi}$ & $\mathrm{WJ}$ & Wi & $\mathrm{Wi}$ & $\mathrm{Wi}$ & Wi \\
\hline Maturity & & WJ & & & & Wi & & & & & \\
\hline Irteres $t$ rates & & & & & & $\mathrm{WJ}$ & & & & & \\
\hline \multicolumn{12}{|l|}{ Expolation } \\
\hline Capitalisation & $S$ & $\mathrm{Wi}$ & W & $\mathrm{WJ}$ & $\mathrm{WJ}$ & Wj & $\mathrm{WJ}$ & Wi & $\mathrm{Wj}$ & $\mathrm{Wj}$ & \\
\hline $\begin{array}{l}\text { Liquidity } \\
\text { Deporit irusaree }\end{array}$ & Wi & $\mathrm{WJ}$ & Wi & $\mathrm{WJ}$ & $\mathrm{Wi}$ & $\mathrm{S}$ & $\mathrm{Wj}$ & W' & $\mathrm{Wi}$ & $\mathrm{Wi}$ & \\
\hline \multicolumn{12}{|c|}{ SECOND STAGE } \\
\hline Soft budget cortraint & $\mathrm{s}$ & $S$ & $\mathrm{~s}$ & $S$ & ? & S & $S$ & S & $\mathrm{WJ}$ & $\mathrm{WJ}$ & Wi \\
\hline Market firsuce & $s$ & $\mathrm{~S}$ & $\mathrm{~S}$ & $\mathrm{~S}$ & $\mathrm{~S}$ & $\mathrm{~s}$ & $\mathrm{~s}$ & $\mathrm{~S}$ & $\mathrm{~s}$ & $\mathrm{~S}$ & $\mathrm{~S}$ \\
\hline Trade ere $\mathbf{i t}$ & $\mathrm{WJ}$ & $\mathrm{WJ}$ & $\mathrm{Wi}$ & $\mathrm{W}$ & $\mathrm{WJ}$ & $\mathrm{WJ}$ & $\mathrm{WJ}$ & $\mathrm{Wj}$ & $\mathrm{WJ}$ & Wi & $\mathrm{Wi}$ \\
\hline Netw ork effect (FDI) & $\mathrm{WJ}$ & $\mathrm{WJ}$ & $\mathrm{W}$ & $\mathrm{Wj}$ & ? & $\mathrm{Wj}$ & $\mathrm{WJ}$ & $\mathrm{Wj}$ & $\mathrm{Wj}$ & $\mathrm{Wj}$ & $\mathrm{Wi}$ \\
\hline \multicolumn{12}{|c|}{. Low/high mask-up sector } \\
\hline SME /s ervice sector & $\mathrm{Wj}$ & $\mathrm{S}$ & $\mathrm{S}$ & $\mathrm{S}$ & $\mathrm{S}$ & $\mathrm{S}$ & $\mathrm{s}$ & $\mathrm{s}$ & $\mathrm{WJ}$ & $\mathrm{s}$ & $\mathrm{S}$ \\
\hline
\end{tabular}

Note: S implies a strengthening of the credit channel, while W refers

to a weakening of the credit channel. 
Table B4-A. Credit Channel - Credit to the Economy

\begin{tabular}{|c|c|c|c|c|c|c|c|c|c|c|c|}
\hline \multirow[t]{2}{*}{$(\%$ of GDF) } & \multicolumn{5}{|c|}{ CEE5 } & \multicolumn{3}{|c|}{ B3 } & \multicolumn{3}{|c|}{ EURO AREA } \\
\hline & $\mathrm{cZ}$ & $\mathrm{HU}$ & PL & SK & SI & $\mathrm{EE}$ & LV & LT & EUR & $\operatorname{Max}$ & MINN \\
\hline Credit to the corpona te sector & 17.5 & 24.3 & 14.7 & 17.0 & 31.2 & 23.1 & 32.2 & 20.1 & 41.0 & 50.6 & 25.2 \\
\hline Crectit to the houreholds & 12.0 & 15.4 & 14.9 & 7.6 & 12.6 & 20.7 & 16.9 & 8.1 & 49.5 & 77.3 & 26.0 \\
\hline For houring puxchases & 8.0 & 10.2 & 5.5 & 6.1 & 2.8 & 16.6 & 11.9 & 5.6 & 33.7 & 67.9 & 13.7 \\
\hline For consumer cre dit & 2.6 & 3.2 & 6.1 & 1.5 & 6.9 & 1.0 & 2.7 & 1.2 & 6.7 & 10.4 & 2.8 \\
\hline For other household lending & 1.4 & 2.0 & 3.3 & NA & 2.8 & 2.2 & 2.3 & 1.3 & 9.1 & 14.1 & 0.9 \\
\hline
\end{tabular}

Source: ECB (2005)

Table B4-B. Credit Channel - The Role of SMEs

\begin{tabular}{|c|c|c|c|c|c|c|c|c|c|c|}
\hline & \multirow[t]{2}{*}{$\begin{array}{l}\text { Priv ate } \\
\text { sector as } \% \\
\text { in GDP }\end{array}$} & \multirow[t]{2}{*}{$\begin{array}{c}\text { SMEs } \\
\% \text { of GDP }\end{array}$} & \multirow[t]{2}{*}{$\begin{array}{c}\text { SME } \\
\text { empi oymert } \\
\text { in totll (\%) }\end{array}$} & \multicolumn{4}{|c|}{$\begin{array}{l}\text { Sectord tirtribution of SMEs (number of } S M E \text { ) } \\
\text { (6) }\end{array}$} & \multicolumn{3}{|c|}{$\begin{array}{l}\text { Fize distribution of } S M E \\
\text { (\%) }\end{array}$} \\
\hline & & & & $\boldsymbol{M}$ & c & $\mathrm{T}$ & $s$ & Misero & Smanl & Me tium \\
\hline \multicolumn{11}{|l|}{ CEE5 } \\
\hline Crech 凡 & 80 & 34 & 64 & 13 & 11 & 35 & 20 & 97 & 2 & 1 \\
\hline Huxgayy & 80 & 57 & 46 & 11 & 9 & 26 & 50 & 85 & 12 & 3 \\
\hline Polsind & 70 & 49 & 62 & 23 & 12 & 36 & 26 & \multicolumn{2}{|c|}{99} & 1 \\
\hline Havak in & 80 & 46 & 32 & 13 & 8 & 44 & 30 & 82 & 14 & 5 \\
\hline Haveria & 65 & 57 & 20 & 18 & 12 & 25 & 69 & 83 & 13 & 4 \\
\hline \multicolumn{11}{|l|}{ B3 } \\
\hline Estorix & 75 & 54 & 65 & 15 & 7 & 37 & 35 & 78 & 10 & 4 \\
\hline Istuin & 65 & 63 & 21 & 14 & 6 & 43 & 35 & 73 & 22 & 5 \\
\hline Lithusmix & 70 & 70 & 32 & 15 & 4 & 39 & 23 & 80 & 16 & 4 \\
\hline \multicolumn{11}{|l|}{ SEE } \\
\hline Eulgavix & 70 & 30 & 65 & 14 & 4 & 51 & 20 & 93 & 6 & 2 \\
\hline Croutia & 60 & 50 & & 15 & 10 & 37 & 6 & & & \\
\hline R.omxrix & 60 & 55 & 40 & 12 & 3 & 63 & 16 & 92 & 7 & 2 \\
\hline
\end{tabular}

Source: World Bank.

Notes: Micro, small and medium SMEs are defined as having 0-9, 10-49 and 50-249 employees, respectively. Defintions defer for Armenia, Moldova, Ukraine, Russia and Uzbekistan, which renders full comparability difficult. The data refer to 2001 except for Russia and Uzbekistan (2003).

$\mathrm{M}=$ manufacturing, $\mathrm{C}=$ construction, $\mathrm{T}=$ trade, $\mathrm{S}=$ services . 


\section{CESifo Working Paper Series}

(for full list see www.cesifo-group.de)

1677 Miguel Portela, Rob Alessie and Coen Teulings, Measurement Error in Education and Growth Regressions, February 2006

1678 Andreas Haufler, Alexander Klemm and Guttorm Schjelderup, Globalisation and the Mix of Wage and Profit Taxes, February 2006

1679 Kurt R. Brekke and Lars Sørgard, Public versus Private Health Care in a National Health Service, March 2006

1680 Dominik Grafenhofer, Christian Jaag, Christian Keuschnigg and Mirela Keuschnigg, Probabilistic Aging, March 2006

1681 Wladimir Raymond, Pierre Mohnen, Franz Palm and Sybrand Schim van der Loeff, Persistence of Innovation in Dutch Manufacturing: Is it Spurious?, March 2006

1682 Andrea Colciago, V. Anton Muscatelli, Tiziano Ropele and Patrizio Tirelli, The Role of Fiscal Policy in a Monetary Union: Are National Automatic Stabilizers Effective?, March 2006

1683 Mario Jametti and Thomas von Ungern-Sternberg, Risk Selection in Natural Disaster Insurance - the Case of France, March 2006

1684 Ken Sennewald and Klaus Waelde, "Itô's Lemma“ and the Bellman Equation for Poisson Processes: An Applied View, March 2006

1685 Ernesto Reuben and Frans van Winden, Negative Reciprocity and the Interaction of Emotions and Fairness Norms, March 2006

1686 Françoise Forges, The Ex Ante Incentive Compatible Core in Exchange Economies with and without Indivisibilities, March 2006

1687 Assar Lindbeck, Mårten Palme and Mats Persson, Job Security and Work Absence: Evidence from a Natural Experiment, March 2006

1688 Sebastian Buhai and Coen Teulings, Tenure Profiles and Efficient Separation in a Stochastic Productivity Model, March 2006

1689 Gebhard Kirchgaessner and Silika Prohl, Sustainability of Swiss Fiscal Policy, March 2006

1690 A. Lans Bovenberg and Peter Birch Sørensen, Optimal Taxation and Social Insurance in a Lifetime Perspective, March 2006

1691 Moritz Schularick and Thomas M. Steger, Does Financial Integration Spur Economic Growth? New Evidence from the First Era of Financial Globalization, March 2006 
1692 Burkhard Heer and Alfred Maussner, Business Cycle Dynamics of a New Keynesian Overlapping Generations Model with Progressive Income Taxation, March 2006

1693 Jarko Fidrmuc and Iikka Korhonen, Meta-Analysis of the Business Cycle Correlation between the Euro Area and the CEECs, March 2006

1694 Steffen Henzel and Timo Wollmershaeuser, The New Keynesian Phillips Curve and the Role of Expectations: Evidence from the Ifo World Economic Survey, March 2006

1695 Yin-Wong Cheung, An Empirical Model of Daily Highs and Lows, March 2006

1696 Scott Alan Carson, African-American and White Living Standards in the $19^{\text {th }}$ Century American South: A Biological Comparison, March 2006

1697 Helge Berger, Optimal Central Bank Design: Benchmarks for the ECB, March 2006

1698 Vjollca Sadiraj, Jan Tuinstra and Frans van Winden, On the Size of the Winning Set in the Presence of Interest Groups, April 2006

1699 Martin Gassebner, Michael Lamla and Jan-Egbert Sturm, Economic, Demographic and Political Determinants of Pollution Reassessed: A Sensitivity Analysis, April 2006

1700 Louis N. Christofides and Amy Chen Peng, Major Provisions of Labour Contracts and their Theoretical Coherence, April 2006

1701 Christian Groth, Karl-Josef Koch and Thomas M. Steger, Rethinking the Concept of Long-Run Economic Growth, April 2006

1702 Dirk Schindler and Guttorm Schjelderup, Company Tax Reform in Europe and its Effect on Collusive Behavior, April 2006

1703 Françoise Forges and Enrico Minelli, Afriat's Theorem for General Budget Sets, April 2006

1704 M. Hashem Pesaran, Ron P. Smith, Takashi Yamagata and Liudmyla Hvozdyk, Pairwise Tests of Purchasing Power Parity Using Aggregate and Disaggregate Price Measures, April 2006

1705 Piero Gottardi and Felix Kubler, Social Security and Risk Sharing, April 2006

1706 Giacomo Corneo and Christina M. Fong, What's the Monetary Value of Distributive Justice?, April 2006

1707 Andreas Knabe, Ronnie Schoeb and Joachim Weimann, Marginal Employment Subsidization: A New Concept and a Reappraisal, April 2006

1708 Hans-Werner Sinn, The Pathological Export Boom and the Bazaar Effect - How to Solve the German Puzzle, April 2006 
1709 Helge Berger and Stephan Danninger, The Employment Effects of Labor and Product Markets Deregulation and their Implications for Structural Reform, May 2006

1710 Michael Ehrmann and Marcel Fratzscher, Global Financial Transmission of Monetary Policy Shocks, May 2006

1711 Carsten Eckel and Hartmut Egger, Wage Bargaining and Multinational Firms in General Equilibrium, May 2006

1712 Mathias Hoffmann, Proprietary Income, Entrepreneurial Risk, and the Predictability of U.S. Stock Returns, May 2006

1713 Marc-Andreas Muendler and Sascha O. Becker, Margins of Multinational Labor Substitution, May 2006

1714 Surajeet Chakravarty and W. Bentley MacLeod, Construction Contracts (or "How to Get the Right Building at the Right Price?”), May 2006

1715 David Encaoua and Yassine Lefouili, Choosing Intellectual Protection: Imitation, Patent Strength and Licensing, May 2006

1716 Chris van Klaveren, Bernard van Praag and Henriette Maassen van den Brink, Empirical Estimation Results of a Collective Household Time Allocation Model, May 2006

1717 Paul De Grauwe and Agnieszka Markiewicz, Learning to Forecast the Exchange Rate: Two Competing Approaches, May 2006

1718 Sijbren Cnossen, Tobacco Taxation in the European Union, May 2006

1719 Marcel Gérard and Fernando Ruiz, Interjurisdictional Competition for Higher Education and Firms, May 2006

1720 Ronald McKinnon and Gunther Schnabl, China's Exchange Rate and International Adjustment in Wages, Prices, and Interest Rates: Japan Déjà Vu?, May 2006

1721 Paolo M. Panteghini, The Capital Structure of Multinational Companies under Tax Competition, May 2006

1722 Johannes Becker, Clemens Fuest and Thomas Hemmelgarn, Corporate Tax Reform and Foreign Direct Investment in Germany - Evidence from Firm-Level Data, May 2006

1723 Christian Kleiber, Martin Sexauer and Klaus Waelde, Bequests, Taxation and the Distribution of Wealth in a General Equilibrium Model, May 2006

1724 Axel Dreher and Jan-Egbert Sturm, Do IMF and World Bank Influence Voting in the UN General Assembly?, May 2006 
1725 Swapan K. Bhattacharya and Biswa N. Bhattacharyay, Prospects of Regional Cooperation in Trade, Investment and Finance in Asia: An Empirical Analysis on BIMSTEC Countries and Japan, May 2006

1726 Philippe Choné and Laurent Linnemer, Assessing Horizontal Mergers under Uncertain Efficiency Gains, May 2006

1727 Daniel Houser and Thomas Stratmann, Selling Favors in the Lab: Experiments on Campaign Finance Reform, May 2006

1728 E. Maarten Bosker, Steven Brakman, Harry Garretsen and Marc Schramm, A Century of Shocks: The Evolution of the German City Size Distribution 1925 - 1999, May 2006

1729 Clive Bell and Hans Gersbach, Growth and Enduring Epidemic Diseases, May 2006

1730 W. Bentley MacLeod, Reputations, Relationships and the Enforcement of Incomplete Contracts, May 2006

1731 Jan K. Brueckner and Ricardo Flores-Fillol, Airline Schedule Competition: ProductQuality Choice in a Duopoly Model, May 2006

1732 Kerstin Bernoth and Guntram B. Wolff, Fool the Markets? Creative Accounting, Fiscal Transparency and Sovereign Risk Premia, May 2006

1733 Emmanuelle Auriol and Pierre M. Picard, Government Outsourcing: Public Contracting with Private Monopoly, May 2006

1734 Guglielmo Maria Caporale and Luis A. Gil-Alana, Modelling Structural Breaks in the US, UK and Japanese Unemployment Rates, May 2006

1735 Emily J. Blanchard, Reevaluating the Role of Trade Agreements: Does Investment Globalization Make the WTO Obsolete?, May 2006

1736 Per Engström and Bertil Holmlund, Tax Evasion and Self-Employment in a High-Tax Country: Evidence from Sweden, May 2006

1737 Erkki Koskela and Mikko Puhakka, Cycles and Indeterminacy in Overlapping Generations Economies with Stone-Geary Preferences, May 2006

1738 Saku Aura and Thomas Davidoff, Supply Constraints and Housing Prices, May 2006

1739 Balázs Égert and Ronald MacDonald, Monetary Transmission Mechanism in Transition Economies: Surveying the Surveyable, June 2006 